UNIVERSIDADE DE SÃO PAULO

FACULDADE DE FILOSOFIA, LETRAS E CIÊNCIAS HUMANAS

DEPARTAMENTO CIÊNCIA POLÍTICA

PROGRAMA DE PÓS-GRADUAÇÃO EM CIÊNCIA POLÍTICA

\title{
POLÍTICA EXTERNA BRASILEIRA PARA O MERCOSUL: INTERESSES ESTRATÉGICOS E CRISE DA INTEGRAÇÃO REGIONAL
}

\author{
Laura Thais Silva
}

Dissertação apresentada ao Programa de Pós-Graduação Ciência Política da Faculdade de Filosofia, Letras e Ciências Humanas da Universidade de São Paulo, para obtenção do título de Mestre em Ciência Política.

Orientador: Prof. Dr. Amâncio Jorge Silva Nunes de Oliveira 


\section{AGRADECIMENTOS}

Inúmeras são as pessoas e instituições que colaboram de alguma maneira num trabalho como este. Aqui registro meu agradecimento a algumas destas pessoas e instituições, deixando a ressalva de que não se trata de uma relação exaustiva.

Aos funcionários da secretaria do Departamento de Ciência Política, pelo apoio, paciência, esclarecimento de inúmeras dúvidas e prontidão em auxiliar não só a mim, mas a todos os alunos do Programa de Pós-Graduação em Ciência Política.

Aos professores do Departamento de Ciência Política, em especial ao Prof. Dr. Rafael Antonio Duarte Villa, pelo apoio e incentivo desde a graduação; à Profa. Dra. Janina Onuki, pelas valiosas sugestões para este trabalho; e ao Prof. Dr. Amâncio Jorge Silva Nunes de Oliveira, que aceitou orientar uma estudante sua desconhecida quando já havia transcorrido uma boa parcela do tempo determinado para a consecução deste trabalho.

A Sandro Lorelli pelo companheirismo, lealdade, apoio e incentivos constantes.

E finalmente à CAPES, pelo financiamento da presente pesquisa. 


\section{SUMÁRIO}

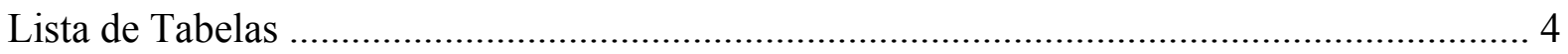

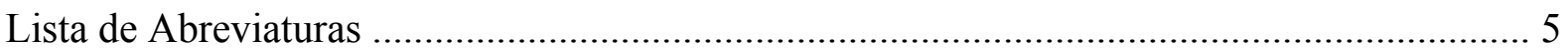

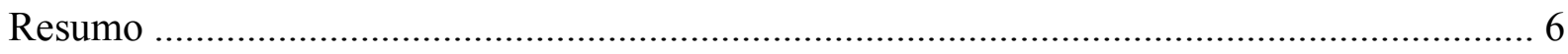

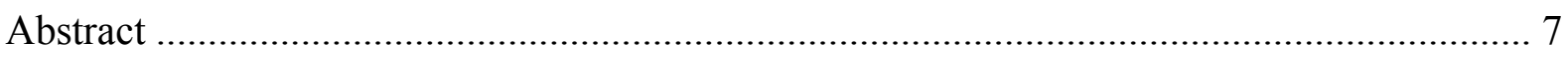

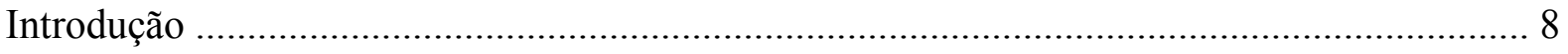

Capítulo 1 - As Teorias das Relações Internacionais e a Integração Regional ........................18

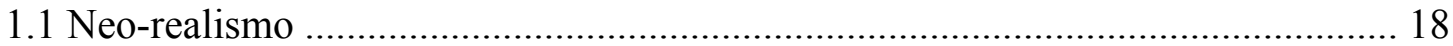

1.2 A interpretação neo-realista da integração regional ........................................ 25

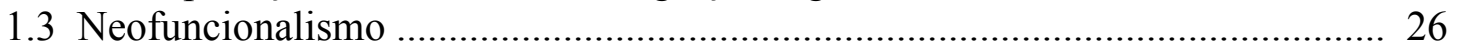

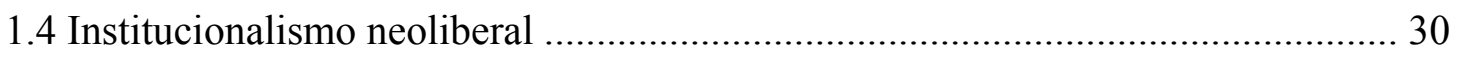

1.5 Considerações Finais do Capítulo ...................................................................... 35

Capítulo 2 - A Política Externa Brasileira e as Divergências com a Argentina ..................... 37

2.1 Breve histórico da política externa brasileira - De Rio Branco a Sarney (1902-

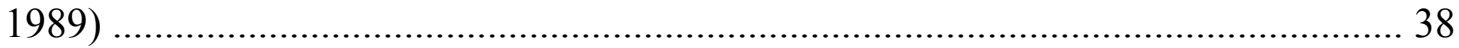

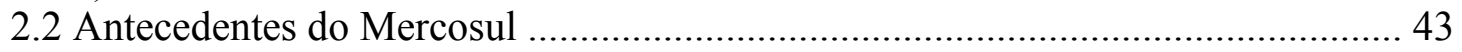

48

2.3 A Política Externa Brasileira e as Integrações Hemisférica e Regional

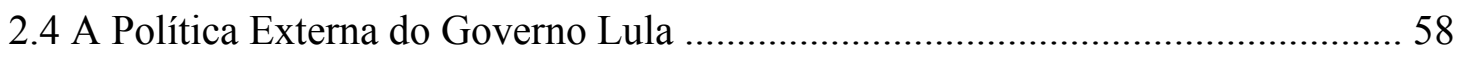

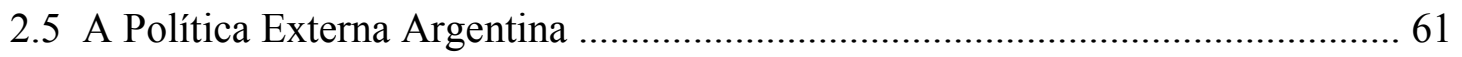

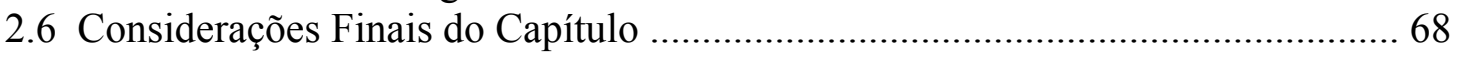

Capítulo 3 - Trajetória Comercial e Institucional do Mercosul .......................................... 71

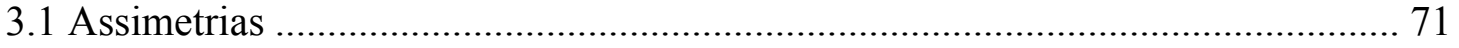

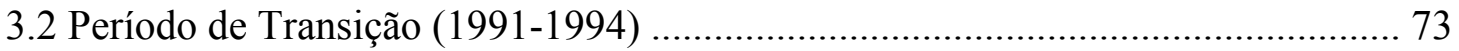

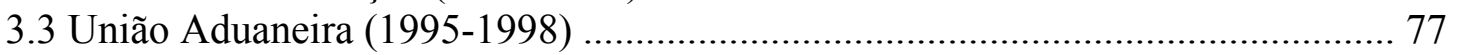

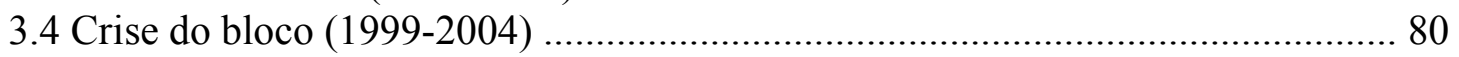

3.5 Sumário da Dinâmica Comercial do Mercosul .................................................. 84

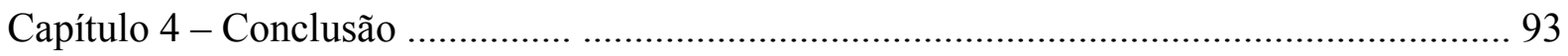

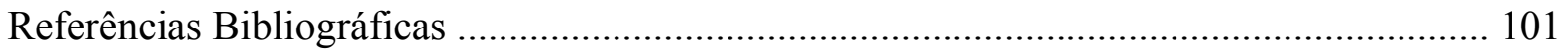




\section{LISTA DE TABELAS}

Tabela 1 - PIB do Mercosul em milhões de dólares correntes............................................. 72

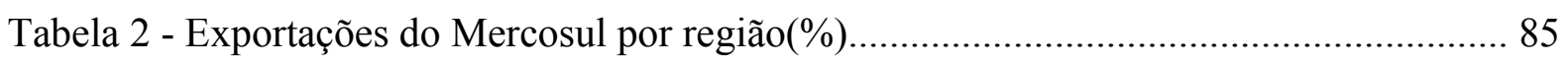

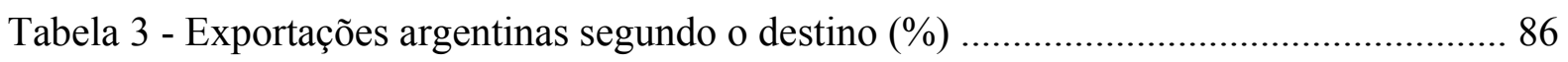

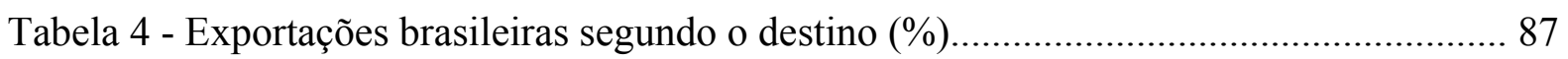

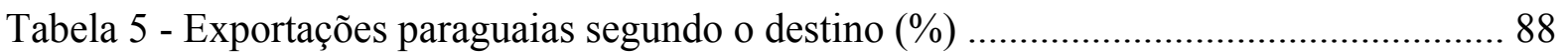

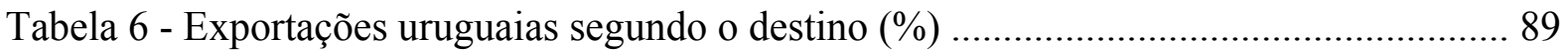

Tabela 7 - Participação das exportações intra-Mercosul no PIB dos Estados membros(\%) .. 91 


\section{LISTA DE ABREVIATURAS}

ACE - Acordo de Complementação Econômica

ALADI - Associação Latino-Americana de Integração

ALALC -Associação Latino-Americana de Livre Comércio

ALCA - Área de Livre Comércio das Américas

ALCSA - Área de Livre Comércio Sul-Americana

ASEAN - Association of South East Asian Nations (Associação das Nações do Sudeste

Asiático)

CAUCE - Convênio Argentino-Uruguaio de Complementação Econômica

CEPAL - Comissão Econômica para a América Latina

CMC - Conselho Mercado Comum

CPC - Comissão Parlamentar Conjunta

FCES - Fórum Consultivo Econômico e Social

GMC - Grupo Mercado Comum

IBAS - Índia, Brasil, África do Sul

MC - Mercado Comum

NAFTA - North America Free Trade Area (Área de Livre Comércio da América no Norte)

ONU - Organização das Nações Unidas

PEC - Protocolo de Expansão do Comércio

PIB - Produto Interno Bruto

PICE -Programa de Integração e Cooperação Econômica

SELA - Sistema Econômico Latino-Americano

SGT(s) - Subgrupo(s) de Trabalho

TEC - Tarifa Externa Comum

UA - União Aduaneiras

UE - União Européia

UNCTAD - United Nations Conference on Trade and Development (Conferência das nações Unidas Sobre Comércio e Desenvolvimento)

ZLC - Zona de Livre Comércio 


\section{RESUMO}

O Mercosul - bloco criado em 1991 a partir da assinatura do Tratado de Assunção por Argentina, Brasil, Paraguai e Uruguai - é um arranjo regional que integra, por meio de uma união aduaneira (imperfeita), as economias dos quatro países que o compõem. Os propósitos iniciais expressos no Tratado de Assunção eram o aprofundamento progressivo da integração a partir de uma Zona de Livre Comércio, chegando até um Mercado Comum, e a criação de mecanismos de harmonização macroeconômica, entre outros objetivos.

Em seus primeiros anos de funcionamento o Mercosul obteve grande sucesso, com a elevação do comércio intra-regional e a intensificação da interdependência entre os Estados membros, mas desde 1999 o bloco experimenta uma crise que se verifica tanto na queda do comércio intra-regional quanto na paralisia da agenda de integração e politização das divergências de interesses entre seus dois maiores sócios: Brasil e Argentina.

A postura brasileira diante da integração - movida por interesses antes estratégicos que comerciais e com um perfil de atuação realista - contribui para a atual situação do Mercosul. Buscando afirmar-se como líder regional e como uma potência média, com capacidade de atuação efetiva em questões internacionais de relevância, o Brasil tem no Mercosul um dos pontos de apoio para sua estratégia, sem que, no entanto, esteja disposto a arcar com determinados custos implicados pela liderança do processo de integração regional.

Palavras-chave: Mercosul; relações internacionais; integração regional; política externa brasileira; instituições internacionais. 
ABSTRACT 
INTRODUÇão

O Mercosul - Mercado Comum do Sul - é um bloco de integração regional que foi criado em 26 de março de 1991, a partir da assinatura do Tratado de Assunção por Argentina, Brasil, Paraguai e Uruguai. Em seu artigo $1^{\circ}$, o Tratado de Assunção afirma que “os Estados-Partes decidem constituir um Mercado Comum, que deverá estar estabelecido a 31 de dezembro de 1994 [...]". Ainda de acordo com o texto desse documento, o estabelecimento do Mercado Comum implicaria

\begin{abstract}
A livre circulação de bens, serviços e fatores produtivos entre os países, através, entre outros, da eliminação dos direitos alfandegários e restrições não-tarifárias à circulação de mercadorias e de qualquer outra medida de efeito equivalente; O estabelecimento de uma tarifa externa comum e a adoção de uma política comercial comum em relação a terceiros Estados ou agrupamentos de Estados $[\ldots]$;

A coordenação de políticas macroeconômicas e setoriais entre os Estados-Partes [...] a fim de assegurar condições adequadas de concorrência entre os EstadosPartes, e o compromisso dos Estados-Partes de harmonizar suas legislações nas áreas pertinentes, para lograr o fortalecimento sobre o processo de Integração. (Tratado de Assunção, Artigo $1^{\circ}$ )
\end{abstract}

A assinatura do Tratado de Assunção deu início ao processo de integração e inaugurou o chamado período de transição. Foram adotadas instituições provisórias, com a previsão de adoção de uma estrutura institucional definitiva em 1994, e mecanismos que deram origem a uma Zona de Livre Comércio (ZLC). Uma ZLC implica a liberalização do comércio por meio da redução de barreiras entre os países membros para a livre troca de bens. O objetivo apontado pelo Tratado de Assunção é o aprofundamento do acordo de integração, de modo que o arranjo de integração não fique restrito à Zona de Livre Comércio, mas passe por etapas sucessivas até a constituição de um Mercado Comum.

O ambicioso objetivo de criação de um mercado comum encontra-se expresso no Tratado de Assunção de 1991. O Mercosul, entretanto, tem enfrentado dificuldades para dar continuidade ao processo de aprofundamento da integração. Depois de um início promissor, com uma crescente intensificação do comércio intra-regional de 1991 a 1998, os 
países integrantes se depararam com desafios relativos ao aprofundamento da integração, conquistando poucos avanços na eliminação de barreiras comerciais não-tarifárias e na coordenação macroeconômica. Desvios em relação aos objetivos, normas e princípios originalmente propostos não têm sido raros, provocando a dificuldade em avançar para etapas mais profundas e arranhões na credibilidade do bloco.

Esse estudo tem como objeto a dinâmica do Mercosul, focalizando o andamento do processo de integração regional e o comportamento de seu maior sócio - o Brasil - em relação ao bloco. A política externa brasileira para o Mercosul também é analisada, sem perder de vista a política externa da Argentina, principal parceiro da integração regional.

A dinâmica comercial é acompanhada desde a criação do bloco, em 1991, a partir de quando há uma crescente intensificação do comércio intra-regional até 2004, passando por aquele momento - demarcado no ano de 1999 - em que houve uma alteração significativa dos padrões de comércio intra-regional, acompanhada por uma maior politização dos conflitos e divergências de interesses entre Brasil e Argentina.

A nossa hipótese é a de que o Brasil vem adotando, em relação ao Mercosul, uma postura essencialmente estratégica, que visa a consolidação de uma posição de liderança sub-regional, alçando o Brasil a uma condição de potência média no cenário internacional. Dentro do projeto estratégico também está a contraposição à hegemonia norte-americana na sub-região. De maneira complementar a esta, desenvolvemos neste trabalho a hipótese de que a postura brasileira em relação ao bloco e as distintas percepções e interesses dos demais membros, sobretudo a Argentina, em relação ao bloco, dificultou a composição de interesses e o aprofundamento da cooperação no âmbito do Mercosul. Dessa forma, a postura estratégica brasileira em relação ao Mercosul tem sido um elemento importante a dificultar o fortalecimento institucional do bloco e o aprofundamento do acordo de integração rumo a um mercado comum.

Com tal fito, analisamos a política externa brasileira para o Mercosul e, em menor medida, a política externa Argentina, à luz das conseqüências ocasionadas para o bloco 
e da interpretação das correntes teóricas das relações internacionais acerca dos processos de integração econômica. De acordo com a nossa hipótese, a postura brasileira pode ser enquadrada numa interpretação realista, ainda que os acordos de integração econômica tenham sido reinterpretados pelas correntes neo-funcionalista e institucionalista como arranjos cooperativos que visam a obtenção de ganhos que não seriam obtidos pelos Estados de maneira isolada.

A integração econômica pode ser definida como

o processo de criação de um mercado integrado, a partir da progressiva eliminação de barreiras ao comércio, ao movimento de fatores de produção e da criação de instituições que permitam a coordenação, ou unificação, de políticas econômicas em uma região geográfica contígua ou não (GONÇALVES et. al., 1998, p. 81).

Historicamente puderam ser observadas diversas formas de integração. Em primeiro lugar pode ser constituída uma Zona de Livre Comércio (ZLC), que implica o livre intercâmbio de bens entre os Estados. Em segundo lugar, pode ser constituída uma União Aduaneira (UA), que implica, além da liberalização do intercâmbio comercial tal como numa ZLC, a adoção de uma Tarifa Externa Comum (TEC) em relação a terceiros países nãomembros. Em terceiro lugar temos o Mercado Comum (MC), em que, além da livre circulação de bens entre seus membros e da União Aduaneira, também se estabelece o livre fluxo de pessoas, serviços e capitais. Em quarto lugar há a União Monetária, que combina as características do Mercado Comum com a harmonização das políticas econômicas nacionais ${ }^{1}$.

É preciso observar que esta classificação não corresponde necessariamente a estágios de integração que se seguem nível a nível; algumas formas mais "profundas" de integração, tais como uma união aduaneira ou mercado comum, podem ser implementadas diretamente, sem fases precedentes, bem como um determinado arranjo pode ser adotado sem que haja qualquer expectativa de se passar a uma nova forma de integração. Além disso, esta classificação nem sempre é adequada para descrever a realidade dos processos de integração atualmente existentes. Conforme vimos acima, o Mercado Comum proposto no Tratado de

\footnotetext{
${ }^{1}$ A classificação clássica destes níveis encontra-se em BALASSA (1961).
} 
Assunção para o Mercosul envolveria não apenas a livre circulação de todos os fatores de produção, mas também a harmonização de políticas macroeconômicas e setoriais.

De qualquer modo, a classificação é útil para demonstrar de que forma o processo de integração pode evoluir passando por etapas cada vez mais profundas de integração. Tal é o objetivo proposto pelo Tratado de Assunção, que deu origem ao Mercosul a partir da criação de uma ZLC e estabeleceu os princípios para constituição de uma União Aduaneira, deixando expressa a intenção de conduzir o processo posteriormente até um Mercado Comum.

Durante o período de transição - de 1991 a 1994 - os fluxos de comércio intraregionais do Mercosul aumentaram de maneira significativa, e a interdependência entre os membros - avaliada pela dinâmica das exportações intra-regionais em relação às exportações totais dos países que compõem o bloco - se aprofundou de maneira notável. Também nesse período os países estabeleceram acordos sobre as principais bases para a constituição da TEC, que entraria em vigor em 1995. Demais acordos, relativos a questões como a coordenação de políticas macroeconômicas e setoriais ainda não haviam sido produzidos.

Em 1994, conforme previsto, foi adotada a estrutura institucional definitiva do bloco, com a assinatura do Protocolo de Ouro Preto. A estrutura institucional consagrada por esse documento continha algumas inovações com relação à estrutura institucional provisória criada pelo Tratado de Assunção, mas conservou as principais características desta: a intergovernamentalidade e o sistema decisório baseado na unanimidade, em que todos os integrantes têm poder de veto.

O período que seguiu à assinatura do Protocolo de Ouro Preto foi marcado por um forte aumento dos fluxos de comércio intra-regionais e da interdependência. Contudo, o bloco passou a acumular uma crescente quantidade de agenda não-concluída A TEC foi inaugurada, dando origem à UA, porém com uma considerável lista de exceções que vem sendo prorrogada. Nesse período também não houve avanço no campo das barreiras nãotarifárias e da coordenação de políticas macroeconômicas. Diferenças de interesses e percepções começaram a se tornarem visíveis. A despeito destes problemas, o forte crescimento do comércio intra-regional transmitia uma imagem de que o Mercosul havia engrenado na marcha da intensificação da integração. 
A partir de 1999, contudo, houve uma alteração significativa na dinâmica comercial do Mercosul e da integração regional como um todo. Esse ano registrou uma queda significativa no fluxo de comércio intra-regional, e desde então os níveis de comércio não voltaram a atingir os patamares alcançados em 1998. Os assuntos pendentes continuaram a se acumular, e as divergências de interesses e percepções foram se tornando mais evidentes e mais politizadas. Questões como a eliminação de barreiras não-tarifárias e a adoção de políticas macroeconômicas comuns permaneceram congeladas. Todos esses fatores também resultaram na paralisia da agenda para o aprofundamento da integração. Do ponto de vista institucional, a única modificação relevante adotada desde o Protocolo de Ouro Preto foi a implementação de um Tribunal Permanente de Revisão, em 2003, a partir da assinatura do Protocolo de Olivos.

Apesar de todos os avanços conquistados de sua criação até 1998, o Mercosul vive hoje uma fase de incertezas. Embora os quatro países tenham acordado quanto ao estabelecimento de uma Tarifa Externa Comum e de políticas convergentes na área macroeconômica, a aplicação da política comercial comum tem sido flexível e comportamentos desviantes em relação aos acordos em torno da TEC não têm sido raros. Ainda não foi completada sequer a universalização da Zona de Livre Comércio para todos os setores; em particular permanecem à parte da ZLC a indústria automotiva e o setor açucareiro.

De acordo com a hipótese aqui desenvolvida, tais incertezas são derivadas de um comportamento por parte do Brasil que procura assegurar os próprios interesses, o que por vezes abala a continuidade do processo de integração. Os interesses e percepções dos dois maiores sócios do Mercosul vêm se tornando inconciliáveis e isso tem dificultado o cumprimento dos acordos estabelecidos no âmbito do bloco e a continuidade do aprofundamento rumo a um Mercado Comum.

Por um lado, o Brasil parece buscar conservar seu peso em relação ao bloco e sua autonomia, sendo portanto resistente a uma maior institucionalização do Mercosul na medida que isso constrangeria sua liberdade de ação. Mas o acordo também é bem-vindo na medida em que consolida a liderança brasileira no plano regional e amplia seu poder de barganha num contexto mais amplo. Em suma, ao Brasil interessa um Mercosul em funcionamento uma vez que isso indicaria uma liderança sub-regional brasileira. 
Do ponto de vista da Argentina, por outro lado, o Mercosul parece responder aos propósitos comerciais mais que aos estratégicos. No momento da constituição do Mercosul a Argentina buscava recuperar sua credibilidade no plano internacional e reconhecia que ocupava posição periférica no sistema internacional, o que foi ilustrado pela formulação da teoria do "realismo periférico" por Carlos ESCUDÉ (1997). Desse modo, as relações com o Brasil e o Mercosul procuravam assegurar o reconhecimento internacional de uma maior estabilidade na região e a viabilidade de uma reforma econômica de cunho neoliberal. Mas neste momento era prioritário para a Argentina resgatar sua credibilidade - abalada pela hiperinflação, pelo processo de desindustrialização e pela Guerra das Malvinas - junto às grandes potências, sobretudo junto aos Estados Unidos. Conciliar o relacionamento com Estados Unidos e Brasil nem sempre foi tarefa fácil para a Argentina. Estabeleceu-se uma relação triangular em que a Argentina buscava o reconhecimento de estabilização por parte dos Estados Unidos, e o relacionamento com o Brasil auxiliava os planos argentinos por meio do superávit da balança bilateral favorável à Argentina e da manutenção do Mercosul como um pólo atraente para novos investimentos (ONUKI, 2002).

O momento de inflexão na dinâmica intra-regional do comércio no Mercosul coincide com o momento da desvalorização do real pelo Brasil, o que provocou na Argentina o temor de que a balança comercial bilateral passasse a ser favorável ao Brasil depois de vários anos em que foram registrados superávits para a Argentina. A despeito disso não ter ocorrido num primeiro momento, a Argentina passou a sofrer uma grave crise econômica a partir de 2001, e desde de 2002 a balança comercial bilateral vem se mostrado por vezes favorável ao Brasil. O déficit comercial em relação ao Brasil é um sério fator de descontentamento da Argentina em relação ao Mercosul, já que o principal interesse argentino no bloco é comercial.

Já no caso brasileiro, a dependência comercial em relação aos parceiros do Mercosul é bem menos evidente. Com destinos bastante diversificados para suas exportações, o Brasil é mais independente em relação aos parceiros sub-regionais. Assim, o Mercosul parece interessar ao Brasil mais do ponto de vista estratégico do que comercial.

Os diferentes interesses e percepções que moveram o Brasil e a Argentina na criação do Mercosul não foram impeditivos no início do processo de integração. Mas tais 
interesses e percepções foram se tornando mais difíceis de conciliar ao longo do tempo. Brasil e Argentina, ao buscar a proteção e a promoção de seus interesses individuais, adotaram um posicionamento em relação ao Mercosul que resultou numa maior politização das divergências e no congelamento do aprofundamento do processo de integração. Isso se refletiu nos fluxos de comércio intra-regionais. Até então crescente, o comércio intra-regional caiu dramaticamente em 1999 e desde então não voltou a alcançar os índices registrados em 1998.

Esse estudo também pretende analisar a dinâmica da integração regional à luz da interpretação das teorias das relações internacionais e sua contribuição para o entendimento dos processos de integração. Desse modo, uma hipótese complementar aqui desenvolvida é a de que a política externa brasileira para o Mercosul apresenta claros traços neo-realistas, o que dificulta a composição de interesses e o aprofundamento da cooperação.

A análise dos fluxos de comércio intra-regionais demonstram que, caso do Mercosul, não se produziu o efeito esperado pela teoria neofuncionalista, de que quanto maior a interdependência entre os países, maiores os incentivos para a cooperação e o aprofundamento do acordo de integração. Além disso, o Mercosul apresenta uma fraca institucionalidade.

De acordo com o neofuncionalismo, níveis crescentes de interdependência conduzem a um processo contínuo de cooperação. Nas palavras de Ernst HAAS, um dos principais representantes do neofuncionalismo, “decisões prévias transbordam (spillover) em novos contextos funcionais, envolvem mais e mais pessoas, clamam por mais e mais contatos e consultas interburocráticos, encontrando novos problemas que crescem para além dos compromissos antecedentes"2 (1961, p. 327).

O conceito de spillover ou transbordamento é um dos conceitos chave para o neofuncionalismo, e representa o efeito pelo qual os primeiros passos do processo de integração geram novos problemas que somente podem ser resolvidos com mais cooperação. Assim, a cooperação entre os Estados em uma determinada área acaba por levar à necessidade de cooperação em outras áreas, que não estavam anteriormente previstas. As instituições também desempenham um papel central de acordo com a abordagem neofuncionalista. A

\footnotetext{
${ }^{2}$ Todas as citações em língua estrangeira deste trabalho são apresentadas em livre tradução.
} 
expectativa desta abordagem é a de que, conforme aumentem as interações econômicas de uma determinada região, os governos em questão se achem na necessidade de um trabalho conjunto baseado em instituições, a fim de garantir que as interações continuem e se expandam.

O neofuncionalismo recebeu inúmeras críticas em virtude de suas predições nem sempre se confirmarem no processo de evolução da integração na Europa, e posteriormente em outras regiões. Contudo, a idéia de que a cooperação entre os Estados e arranjos formais de integração derivam do aumento da interdependência, bem como a idéia de que as instituições internacionais desempenham um papel significativo na cooperação, continuaram a alimentar novas abordagens para a questão da integração regional. Tais idéias são a base do institucionalismo neoliberal, "a abordagem teórica mais influente no estudo recente da cooperação internacional e [que] constitui uma teoria altamente plausível e generalizável para o entendimento do ressurgimento do regionalismo" (HURRELL, 1995, p. 42).

Assim como o neofuncionalismo, o institucionalismo argumenta que o aumento dos níveis de interdependência tem o efeito de gerar uma maior demanda por cooperação. Entretanto, dadas as características do sistema internacional - descentralização, incertezas e imprevisibilidade quanto as reais intenções dos demais atores, entre outras - é necessária a criação de mecanismos que ajudem os Estados a superar seus problemas de ação coletiva. As instituições são vistas por esta abordagem como a solução para estes problemas, conferindo maior transparência e previsibilidade ao relacionamento entre os Estados. As normas, regras e procedimentos das instituições e regimes internacionais são criadas porque auxiliam os Estados a eliminar os problemas de ação coletiva, fazendo com que possam lidar conjuntamente para a superação de problemas comuns.

As instituições desempenham tarefas que são importantes porque influenciam os cálculos dos atores e a maneira como estes definem seus interesses. Dentre as tarefas desempenhadas pelas instituições estão o fornecimento de informações, a promoção de uma maior transparência e previsibilidade, a redução dos custos de transação, a facilitação de interconexão entre as diferentes pautas da agenda internacional e o fornecimento de pontos focais para a cooperação. 
Uma terceira abordagem para o estudo das relações internacionais, o neorealismo, enfatiza - assim como o realismo clássico - a importância das configurações de poder do sistema internacional, a natureza anárquica desse sistema e a competição entre os Estados pelo poder. Bem menos otimista em relação aos processos de integração que o neofuncionalismo e o institucionalismo, essa abordagem afirma que os arranjos regionais são, em sua essência, similares à política de formação de alianças: instáveis, os arranjos de integração somente tendem a se manter enquanto corresponderem aos interesses individuais dos Estados que os integram. De acordo com o neo-realismo os agrupamentos regionais são formados como resposta a desafios externos enfrentados pelos Estados. Por essa razão os neorealistas não fazem distinção entre regionalismo econômico e político.

Os Estados são descritos pelo neo-realismo como unidades racionais egoístas, que atuam estrategicamente na perseguição de seus próprios interesses, definidos em termos de segurança, auto-preservação e capacidades de poder. Por essa razão, e dados os condicionamentos do sistema internacional, a cooperação entre os Estados é pouco provável. Ao se envolverem em processos de integração, os Estados não estão agindo de forma cooperativa tendo em vista o bem-estar comum, mas sim buscando aumentar seu poder relativo frente a terceiros Estados ou agrupamentos de Estados. Além disso, os Estados estão, segundo o neo-realismo, constantemente preocupados com a questão dos ganhos relativos: a distribuição dos ganhos entre os atores envolvidos em um processo de integração.

Estas três abordagens - neofuncionalismo, institucionalismo neoliberal e neorealismo - servirão de base para este estudo, fornecendo as fundamentações teóricas necessárias. Assim, no primeiro capítulo estas três vertentes são apresentadas mais detalhadamente, com seus principais supostos teóricos e suas principais expectativas acerca dos processos de integração regional.

No segundo capítulo é analisada a política externa do Brasil para o Mercosul e seu comportamento em relação ao bloco, considerando-se também a política externa argentina. Procura-se averiguar de que modo o Mercosul tem sido um instrumento da promoção dos interesses destes dois países e as divergências resultantes dos diferentes interesses do Brasil e da Argentina. 
No terceiro capítulo é analisada a evolução do Mercosul, em termos de sua estrutura institucional e em termos comerciais. Com a finalidade de traçar um quadro da dinâmica de interdependência entre os Estados-partes e de suas assimetrias, nesse segundo capítulo também são apresentados os principais indicadores de comércio intra-regional e dados concernentes ao peso relativo representado pelos integrantes do bloco.

Finalmente, no quarto capítulo são apresentadas as conclusões deste estudo, obtidas a partir da compreensão de como estes dois fatores - a evolução do Mercosul e a condução da política externa brasileira em relação ao bloco - se relacionam, tomando-se por base as teorias racionalistas das relações internacionais e sua interpretação acerca dos processos de integração regional. 


\section{Capítulo 1 - As Teorias das Relações Internacionais e a Integração Regional}

1.1 Neo-realismo

Foi a partir da II Guerra Mundial, com a falência da Liga das Nações e sua incapacidade de manter a paz que ocorreu a ascensão do estudo "científico" das relações internacionais. Até então o tema das relações entre Estados não havia sido estudado de maneira sistemática. Neste contexto duas obras despontam como importantes estudos da realidade internacional: Vinte Anos de Crise: 1919-1939, de Edward CARR, e A Política Entre as Nações, de Hans Morgentthau Ambos os autores procuram imprimir, nestas obras, uma posição "realista" frente ao que se passa no relacionamento entre os Estados, distanciando-se do "idealismo" que estava presente no período entreguerras e na criação da Liga das Nações ${ }^{3}$.

De acordo com MORGENTHAU, adotar uma postura realista significa reconhecer que

\begin{abstract}
tendo em vista que vivemos em um universo formado por interesses contrários, em conflito contínuo, não há possibilidade de que os princípios morais sejam algum dia realizados plenamente, razão por que, na melhor das hipóteses, devem ser buscados mediante o recurso, sempre temporário, ao equilíbrio de interesses e à inevitavelmente precária solução dos conflitos (2003, p. 4).
\end{abstract}

Desponta como característica central do realismo, portanto, a afirmação de que o conflito está sempre presente na relação entre os Estados, seja de modo deflagrado ou potencial, e que apenas ideais relacionados com a moralidade não são suficientes para que o sistema internacional se torne mais pacífico. De acordo do o realismo, a tendência ao conflito reside na própria natureza humana, o que aproxima esta teoria da concepção presente na obra do filósofo Thomas HOBBES (1999), para quem a competição, a desconfiança e a busca da glória levam os homens, na ausência de uma autoridade central que os possa conter, à guerra,

\footnotetext{
${ }^{3}$ Para uma abordagem histórica do desenvolvimento do estudo das relações internacionais ver CASTRO (2005).
} 
"uma guerra que é de todos os homens contra todos os homens", e que perdura, "pois a guerra não consiste apenas na batalha, ou no ato de lutar, mas naquele lapso de tempo durante o qual a vontade de travar batalha é suficientemente conhecida" (p. 109).

$\mathrm{O}$ reconhecimento de que inexiste qualquer autoridade central acima dos Estados que os obrigue à obediência, de que os Estados competem entre si em razão disto, e de que seu relacionamento é cercado de desconfiança são suposições fundamentais do realismo.

Mais recentemente o autor realista John Mearsheimer sintetizou os principais elementos da teoria realista acerca do sistema internacional em cinco itens. O primeiro destes elementos é a suposição de que o sistema internacional é anárquico. Em princípio e por si só, a anarquia não significa que o sistema internacional seja inerentemente conflituoso; a anarquia é um princípio ordenador, e significa apenas que o sistema consiste de Estados independentes, sem nenhuma autoridade central que se coloque acima deles.

A segunda suposição é a de que os Estados possuem sempre algum tipo de capacidade militar ofensiva, tornando-os potenciais agressores. As capacidades militares podem variar muito, e alguns Estados possuem mais força do que os outros, tornando-os mais perigosos. A terceira suposição é a de que os Estados nunca podem ter certeza quanto às intenções dos demais Estados, e por essa razão temem que outros Estados estejam dispostos a utilizar sua capacidade militar ofensiva para atacá-los. Em quarto lugar supõe-se que o objetivo primordial dos Estados no sistema internacional é garantir sua própria sobrevivência. "Especificamente, os Estados procuram manter sua integridade territorial e a autonomia de sua ordem política doméstica. [...] Os Estados podem perseguir outros objetivos, obviamente, mas a segurança é o objetivo mais importante” (MEARSHEIMER, 2001, p. 31).

Finalmente, a quinta suposição é a de que os Estados são atores racionais, com capacidade para perceber seu ambiente externo e que atuam estrategicamente na perseguição de seus interesses.

Mearsheimer tem como maior preocupação a atuação das grandes potências, mas estas suposições realistas são válidas para todos os Estados, observando-se que Estados de menor força militar são mais limitados em suas estratégias. O que o autor procura evidenciar, é que, combinadas, as características enumeradas acima resultam em "poderosos 
incentivos para que as grandes potências pensem e atuem ofensivamente umas em relação às outras" (idem, p. 32). O conflito, o medo, e a busca pela maximização do poder são, assim, traços constantemente presentes nas relações entre Estados.

De acordo com a interpretação realista, os Estados são os únicos atores relevantes das relações internacionais. Os Estados são unidades estratégicas que agem racionalmente na busca de seus interesses. Em função dos condicionamentos do sistema internacional, os Estados tendem a priorizar as questões estratégicas de segurança em suas agendas de política externa, havendo, portanto, uma divisão entre questões de "alta política", aquelas que se relacionam com a segurança, soberania e capacidades de poder, e as questões de "baixa política", todas as que não são diretamente relacionadas com elementos estratégicos e que assumem uma posição secundária nas agendas de política externa, tais como meio ambiente, economia etc.

Dadas as características do sistema internacional não haveria, para o realismo, qualquer possibilidade de cooperação entre os Estados. Todos os Estados são inimigos potenciais e quando há alguma forma de aproximação entre os Estados ela se dá de forma defensiva e esporádica: há a possibilidade de que dois ou mais Estados sejam aliados numa guerra, mas, terminado o conflito, todos os Estados voltam a ser inimigos potenciais.

O realismo praticamente dominou as discussões sobre relações internacionais após a II Guerra. A partir da década de 70, contudo, a escola realista passou a sofrer críticas mais contundentes. O sistema internacional experimentava novos movimentos naquele período. Delineavam-se as primeiras características do movimento que passou a ser conhecido como globalização e emergiam diversos regimes internacionais, cobrindo uma variada gama de temas que ganhavam maior visibilidade na esfera internacional, tais como meio ambiente e direitos humanos. Foi nesse contexto que surgiu o institucionalismo, que será examinado adiante, uma explicação teórica alternativa segundo a qual é possível a cooperação entre os Estados.

As explicações alternativas passaram a representar um desafio à teoria realista. Mas, longe de ser abandonada como perspectiva válida para explicar o relacionamento entre os Estados, o realismo sofreu uma reavaliação conceitual importante neste período. A teoria realista foi revigorada por meio do neo-realismo. 
Constituindo um refinamento da teoria realista clássica, o neo-realismo conserva a idéia de que são poucas as perspectivas para o estabelecimento da cooperação internacional e de relações pacíficas entre os Estados. As principais suposições do realismo clássico são mantidas, com algum refinamento, e algumas inovações são lançadas.

Um dos refinamentos importantes do neo-realismo é o levantamento do problema dos ganhos relativos, um dos fatores a dificultar o estabelecimento de cooperação e de relações pacíficas entre os Estados. O neo-realismo mantém a suposição de que as características do sistema internacional conduzem a uma situação de incerteza e desconfiança recíproca entre os Estados, e que, portanto, qualquer Estado é um inimigo potencial. Em razão disso, os Estados buscam continuamente aumentar seus recursos de poder:

\footnotetext{
Apreensivos em relação às verdadeiras intenções dos demais Estados, e conscientes de que atuam em um sistema de auto-ajuda, os Estados rapidamente compreendem que o melhor meio de garantir sua sobrevivência é ser o Estado mais poderoso do sistema. Quanto mais forte for um Estado relativamente a seus rivais potenciais, menor é a probabilidade de que qualquer um dos seus rivais irá atacá-lo e ameaçar sua sobrevivência. [...] De fato, quanto maior for a diferença de poder entre quaisquer dois Estados, menor a possibilidade de que o mais fraco irá atacar o mais forte (idem, pp. 33-34).
}

A conseqüência disto é, segundo os autores neorealistas, que a distribuição de poder no sistema internacional é uma preocupação central dos Estados. Cada Estado procura maximizar a sua parcela de poder, e preocupa-se quando perde poder relativamente a outros Estados. A busca pela maximização de poder só termina quando um Estado conquista a hegemonia, situação em que elimina a possibilidade de ser desafiado por qualquer outro Estado, dada a diferença nas capacidades de pode entre ele e os demais Estados.

Surge, assim, como uma inovação do neo-realismo, a idéia de realismo estrutural ou sistêmico, segundo a qual o comportamento dos Estados é condicionado pela “estrutura" do sistema internacional, isto é, pela forma como o poder se distribui entre os Estados. A interpretação neo-realista, portanto, afirma que a configuração do poder constitui a estrutura do sistema e condiciona as estratégias disponíveis, de acordo com a posição que o Estado ocupa no sistema internacional. Essa idéia é expressa por WALTZ (2002): 
Uma estrutura é definida pela disposição das suas partes. Apenas as mudanças de disposição são mudanças estruturais. Um sistema é composto de uma estrutura e das partes que interagem [isto é, os Estados]. [...] Uma vez que a estrutura é uma abstração, não pode ser definida enumerando características materiais do sistema. Deve, em vez disso, ser definida pela disposição da partes do sistema e pelo princípio dessa disposição (p. 115).

É a forma como estão dispostos os Estados no sistema internacional, ou mais precisamente o número de grandes potências que, de acordo com o realismo estrutural, caracteriza a estrutura do sistema. Desse modo, pode haver uma configuração unipolar, quando há uma única grande potência em destaque; bipolar, quando duas grandes potências rivais se sobressaem diante dos demais Estados, sem que qualquer uma delas consiga dominar a outra; e multipolar, quando três ou mais potências disputam a condição de supremacia do sistema. De acordo com as suposições do realismo estrutural, a distribuição de poder limita as estratégias dos atores e fornece incentivos para que se forme uma balança de poder, sendo este outro conceito caro ao neo-realismo. É a forma como o poder está distribuído, em suma, que determina a configuração do sistema e que constitui o seu princípio ordenador.

É quando o sistema tem uma configuração unipolar que se configura uma situação de hegemonia. "Um hegemon é um Estado tão poderoso que domina todos os demais Estados do sistema" (MEARSHEIMER, 2001, p. 40). Nenhum outro Estado tem, sob uma situação de hegemonia, condições militares de desafiar a única grande potência do sistema.

Embora a definição se refira a uma única potência que domina todo o sistema, a definição pode ser ampliada para cobrir situações em que um Estado exerça um papel de liderança em uma determinada região, situação em que poderíamos nos referir a um hegemon regional e distinguir entre a hegemonia regional e a hegemonia global.

O Estado que atinge a posição de hegemon no sistema internacional teria as condições e muitas vezes os incentivos para a conformação de regimes e instituições internacionais com a finalidade de consolidar seu poder e condicionar ainda mais o comportamento dos demais Estados. Dito de outra maneira, uma distribuição hegemônica do poder gera regimes e instituições porque é do interesse do Estado hegemônico a condução de tal política e porque ele possui os recursos necessários para sustentar o funcionamento efetivo de tais instituições. 
Embora reconheça, portanto, que os regimes e instituições podem existir e serem efetivos, o neo-realismo argumenta que a sua efetividade depende do poder da potência hegemônica e de seu interesse de mantê-los; os regimes e instituições não possuem uma dinâmica própria capaz de influenciar o comportamento e as estratégias dos Estados. De acordo com esta perspectiva há a necessidade de um Estado com a capacidade de sustentar os regimes para que estes sejam efetivos. É por isso que, em última instância, os Estados são os únicos atores relevantes do sistema internacional. Segundo a interpretação neo-realista, nenhuma forma de regime pode manter-se sem o apoio de uma grande potência, e por essa razão os regimes e instituições não podem ser considerados "atores" do sistema internacional. Sendo reflexo da ação de um Estado poderoso, os regimes e instituições internacionais não possuem força autônoma para "atuar" no sistema internacional.

A perspectiva realista acerca dos regimes e instituições internacionais diverge amplamente da perspectiva institucionalista. Conforme afirma MEARSHEIMER (1994),

\begin{abstract}
Realistas e institucionalistas particularmente discordam a respeito da possibilidade das instituições afetarem de maneira pronunciada as perspectivas de estabilidade internacional. Os realistas dizem que não; os intitucionalistas dizem que sim. Os realistas sustentam que as instituições são basicamente um reflexo da distribuição de poder no mundo. Elas são baseadas nos cálculos auto-interessados das grandes potências, e não exercem efeito independente sobre o comportamento estatal. Os realistas acreditam, portanto, que as instituições não são um fator importante para a paz. Elas importam apenas marginalmente. Os institucionalistas desafiam diretamente esta perspectiva $[\ldots]$ (p.7).
\end{abstract}

O surgimento dos regimes, por um lado, e a adesão dos Estados a tais regimes, por outro, são, segundo a interpretação neo-realista, fruto da distribuição de poder e das estratégias dos Estados. Dois motivos principais são apontados pelos autores realistas para justificar a adesão dos Estados aos regimes. Por um lado, há as grandes potências, a quem os regimes são convenientes ao refletir seus próprios interesses e preferências. Por outro lado, há os pequenos Estados, limitados em suas estratégias, compelidos a aderir aos regimes em função das suas limitações. Não podendo confrontar as grandes potências, procuram tirar algum proveito do alinhamento junto a elas. Em suma,

Os realistas também reconhecem que às vezes os Estados atuam por meio de instituições. Contudo, acreditam que aquelas regras refletem os cálculos 
estatais de auto-interesse baseados principalmente na distribuição internacional de poder. Os Estados mais poderosos do sistema criam e modelam as instituições de tal modo que possam manter sua parcela de poder mundial, ou até mesmo ampliá-la (idem, p. 13).

De acordo com o neo-realismo, portanto, o papel das instituições internacionais é muito limitado. As instituições não chegam a exercer uma influência significativa no comportamento dos Estados. Ao contrário, os Estados apenas aderem às instituições enquanto elas servirem aos seus interesses. Caso contrário, caso não correspondam aos objetivos dos Estados, estes permanecem à parte das instituições ou deixam de levar em conta os princípios por elas previstos. As instituições e regimes não são criados facilmente, e também não são facilmente mantidos.

Duas razões principais inibem o comportamento cooperativo entre Estados e a criação e manutenção de instituições internacionais, de acordo com a perspectiva realista. Em primeiro lugar, o risco da trapaça e da falta de confiabilidade. Sem qualquer autoridade superior que possa garantir o cumprimento de acordos, os Estados nunca podem estar certos quanto ao comportamento dos demais estados em relação às instituições. E, em segundo lugar, o problema acima referido dos ganhos relativos. Os Estados temem que um arranjo cooperativo possa significar ganhos distintos para os Estados envolvidos, provocando alterações nas capacidades relativas de poder. Assim, o problema dos ganhos relativos seria um constrangimento importante a inibir a criação de instituições.

\footnotetext{
Mesmo que o Estado esteja confiante de que um parceiro não fará uso dos diferenciais dos ganhos contra si no presente ou num futuro previsível, ainda assim ele pode temer tais diferenciais porque não pode ter certeza de que novos líderes ou um novo regime em um futuro mais distante possa tornar um parceiro mais propenso e motivado a empregar os diferenciais de maneira danosa contra si (GRIECO, 1993, p. 314).
}

Há uma preocupação dos Estados de que os sócios de hoje possam ser os inimigos de amanhã, e um medo de que os ganhos advindos de um arranjo comum com um atual sócio possam significar no futuro vantagens para um potencial inimigo. Conseqüentemente, os Estados precisam destinar muita atenção não apenas aos seus próprios ganhos, mas também aos ganhos dos sócios. Os Estados são, de acordo com a perspectiva realista, extremamente sensíveis a qualquer erosão em suas capacidades relativas, as quais são 
a base fundamental para sua segurança num contexto anárquico. Por isso os realistas argumentam que além do objetivo de conquistar o maior ganho individual possível, os Estados também procuram obter, em arranjos cooperativos, a garantia de que os outros Estados não obtenham avanços em suas capacidades relativas. Os Estados sempre avaliam seu desempenho em um relacionamento em termos do desempenho dos outros Estados. Assim, é possível prever que os Estados irão limitar seu comprometimento ou mesmo abandonar acordos de cooperação se acreditarem que seus sócios estão adquirindo, ou podem potencialmente adquirir, ganhos relativamente maiores.

\section{2 - A InterpretaÇÃo Neo-Realista da Integração Regional}

Frente a todos fatores de inibição apontados por essa teoria, o estabelecimento de arranjos cooperativos entre os Estados só ocorre, de acordo com o neo-realismo, por razões essencialmente estratégicas. No caso dos acordos de integração, a motivação é a busca por mais segurança e maior poder de barganha frente a terceiros países ou blocos, o que é chamado de regionalismo tático. Dadas as suposições dessa teoria de um sistema internacional anárquico e conflituoso, em que os Estados são entes racionais que atuam estrategicamente na busca de seus interesses em termos de segurança e capacidades de poder, os arranjos regionais são vistos pelos neo-realistas como funcionando similarmente a alianças estratégicas: uma associação de Estados contrapondo-se a outros Estados em busca de um objetivo comum, sobretudo o aumento de seu poder de barganha.

Ainda assim, esses arranjos tendem a ser, sob a ótica neo-realista, extremamente instáveis: sua continuidade dependerá da distribuição de poder entre os membros, sendo que os Estados preocupam-se mais com os ganhos relativos que com os ganhos absolutos obtidos por meio da integração.

Se o padrão das interações econômicas intra-regionais num passado recente estiver associado a (e talvez tenha contribuído para) uma estabilidade nas capacidades econômicas relativas, os Estados menos poderosos da região 
podem ficar menos temerosos de que sua posição relativa irá piorar ainda mais [...] como resultado dos laços econômicos mais estreitos com os parceiros mais fortes $[\ldots]$.

Em contraste, se os países menos poderosos de uma região tiverem experimentado ou estiverem experimentando uma deterioração significativa de suas capacidades relativas, então eles podem temer que o incremento dos laços econômicos regionais promovido pela institucionalização possam acentuar os desequilíbrios de capacidade regionais ainda mais em favor dos parceiros relativamente mais fortes (GRIECO, 1997, p. 176)

Os processos de integração não são irreversíveis. Determinadas condições sistêmicas específicas possibilitam sua emergência, mas, uma vez que deixem de existir tais condições, a opção dos arranjos regionais é descartada.

Estrategistas racionais, os Estados somente optam por arranjos regionais quando os ganhos representados pela integração superam os custos implicados, bem como os ganhos que seriam obtidos pela interação direta e isolada com cada um dos demais atores envolvidos.

Ainda que sejam projetos de integração econômica, os arranjos regionais são essencialmente projetos de natureza política, em que estão presentes questões defensivas. Por meio do regionalismo tático os Estados buscam assegurar uma maior previsibilidade no relacionamento com os parceiros do arranjo regional e aumentar tanto sua capacidade de resistência diante de pressões internacionais bem como seu poder de barganha. Arranjos regionais são constituídos pelos Estados para que estes possam conquistar objetivos que não seriam passíveis de serem obtidos individualmente. Representam, pois, os interesses dos Estados que os compõem, e não se mantêm se tais interesses não forem correspondidos.

\section{3 - NeOfunCiOnALismo}

O neofuncionalismo constitui uma das primeiras análises teóricas preocupadas especificamente com os processos de integração regional. A teoria funcionalista foi formulada para explicar a criação e os primeiros passos da Comunidade Européia - hoje União Européia. 
Dentre os primeiros autores a buscar explicações para os processos de integração regional destacam-se David Mitrany e Ernst Haas.

Os autores funcionalistas que buscavam explicar os primeiros desenvolvimentos da integração na Europa se concentravam nas condições favoráveis aos movimentos para uma integração econômica e na relação entre o aprofundamento da integração econômica e as chances de integração política e construção da paz. Nas palavras de MITRANY,

\begin{abstract}
Se se pudesse visualizar um mapa do mundo mostrando as atividades econômicas e sociais, ele se pareceria com uma intricada teia de interesses e relações passando e repassando as divisões políticas - não um mapa bélico de Estados e fronteiras, mas um mapa pulsando com as realidades da vida diária. Elas são a base natural para as organizações internacionais: e a tarefa é trazer este mapa, que é uma realidade em funcionamento, para o governo conjunto internacional, ao menos em suas linhas essenciais. Com o tempo as linhas políticas serão então superpostas e apagadas por essa teia de relações e administrações conjuntas" (1948, pp. 358-359).
\end{abstract}

Mitrany observava que o século XX encerrava uma grande quantidade de problemas técnicos cuja solução não seria possível senão por meio de uma ação conjunta para além das fronteiras estatais. As proposições de Mitrany caminham no sentido de romper com a lógica da autoridade ligada a um território, por meio da transferência de autoridade para um corpo técnico, visando a solução de tarefas que transcendem os territórios nacionais. O caráter técnico de tais problemas exigiria um tratamento especializado que os políticos não têm condições de exercer, e por essa razão a cooperação interestatal para a resolução de problemas ficaria isenta de conteúdo político e conseqüentemente destituída de conflito:

[...] os arranjos funcionais têm a virtude da auto-determinação técnica, uma das principais razões para torná-las mais prontamente aceitáveis. A natureza de cada função já diz sobre seu próprio escopo e sobre os poderes exigidos para sua performance efetiva (idem, p. 358).

Tal cooperação técnica seria o passo inicial para a emergência de uma rede cada vez mais densa de cooperação, criando espaço para a emergência de órgãos administrativos moldados de acordo com a natureza de cada tarefa. MATTLI resume da seguinte forma as proposições de Mitrany: 
[...] As divisões políticas são uma fonte de conflito entre as nações. Estas divisões podem ser transcendidas apenas gradualmente pela procura de áreas de reciprocidade e o estabelecimento de uma teia em funcionamento de instituições internacionais funcionais, administradas pelas elites técnicas, nas quais e por meio das quais os interesses de todas as nações são gradualmente integrados. (1999, p. 22).

Desse modo os regimes e instituições internacionais seriam progressivamente criados e consolidados. Além disso, Mitrany acreditava que a cooperação em uma determinada área técnica daria origem à necessidade de mais cooperação em áreas contíguas, intensificando e ampliando o escopo da ação cooperativa, processo que configura o pressuposto central da teoria neofuncionalista, a que Mitrany chamava de ramificação.

O processo de ramificação apontado por Mitrany ficou consagrado na literatura neofuncionalista como spillover, o efeito pelo qual os primeiros passos do processo de integração geram novos problemas que somente podem ser resolvidos com mais cooperação. A expectativa do efeito de spillover, portanto, é a de que a cooperação iniciada em uma determinada área produza a necessidade de expansão da cooperação para áreas que não estavam previstas, num processo sempre crescente.

Autores neofuncionalistas, tais como Ernst Haas e Philippe Schmitter, desenvolveram suas idéias com base nesse pressuposto central de spillover, qualificando-o como o processo pelo qual os Estados decidem "aumentar simultaneamente tanto o escopo quanto o nível de seu comprometimento" (SCHMITTER, 1970, p. 846) em arranjos conjuntos, na medida em que efeitos inesperados da cooperação em uma determinada área criam a necessidade de mais cooperação.

De acordo com a teoria neofuncionalista, as elites nacionais, sejam elas governamentais ou do setor privado, tendem a se articular com as elites dos demais países cujos interesses e expectativas sejam convergentes com seus próprios interesses e expectativas na promoção de instâncias supranacionais que possam garantir a conquista de seus objetivos. Como resultado, crescem os níveis de interdependência interestatal e surgem novos efeitos que requerem que a cooperação seja estendida para novas áreas. Esse processo de transbordamento para novas tarefas, ou seja, o efeito de spillover, transforma-se em um mecanismo de realimentação, sustentando o arranjo cooperativo por suas próprias dinâmicas, e expandindo-o. 
O aumento dos níveis de interdependência e o processo de spillover podem desembocar na integração política. Entretanto, a integração tem início num contexto econômico, social ou técnico, ou seja, apolítico. De acordo com o neofuncionalismo, as instituições supranacionais são o mecanismo mais eficaz para solucionar os problemas comuns e operar a politização dos assuntos inicialmente apolíticos. Por isso, a partir de um determinado quantum de cooperação haveria incentivos para a adoção de instituições supranacionais.

Há também no conceito de spillover a idéia de que o aprofundamento da integração gera a mobilização de grupos de interesse das sociedades envolvidas em favor do processo. Essa mobilização tem o efeito de tornar o processo de integração menos dependente da ação dos governantes. Não só os políticos como outros atores internos, ao perceberem que a integração gera mais benefícios econômicos do que sacrifícios, tornam-se sustentadores do processo. Desse modo, o spillover ocorre quando os segmentos beneficiados permanecem obtendo ganhos, ao mesmo tempo em que eventuais prejudicados são apaziguados por meio de medidas compensatórias por parte dos governos.

Uma vez que as interpretações neofuncionalista nem sempre se confirmaram ao longo do desenvolvimento da Comunidade Européia, essa teoria sofreu diversas críticas. As principais delas são as de que a teoria subestima a resistência dos Estados à integração política e as lealdades nacionais; que subestima as diferenças existentes entre os assuntos de "baixa política", que podem ser tratados de maneira tecnocrática, e os assuntos de "alta política", que não podem ser delegados a especialistas técnicos devido às suas implicações para a soberania estatal; que desconsidera o papel mutável de fatores externos tanto no campo político e de segurança quanto no campo econômico; e que é determinista, tecnocrática e apolítica, ignorando fatores como os conflitos políticos e distributivos entre os países e as diferentes alternativas para administrá-los (FAWCET e HURRELL, 1995, p. 60; MATTLI, 1999, p. 23, 27-28).

A despeito das críticas sofridas, o neofuncionalismo ainda exerce grande influência nos debates acerca dos processos de integração regional, e alguns de seus pressupostos básicos estão presentes em outras influentes teorias da cooperação internacional e integração regional. 


\section{4 - Institucionalismo NeOLiberal}

Foi a partir da década de 70 que o institucionalismo neoliberal passou a exercer uma grande influência nos debates sobre cooperação internacional. A explicação institucionalista enfatiza o papel dos regimes e instituições internacionais como mecanismos para solucionar problemas de ação coletiva e ressalta a interdependência existente entre os Estados como fator importante a estimular o surgimento de relações mais cooperativas. $\mathrm{O}$ institucionalismo admite algumas das suposições fundamentais do realismo - notadamente a anarquia do sistema internacional e o reconhecimento dos Estados como atores egoístas que atuam estrategicamente na perseguição de seus objetivos - mas discorda que elas impossibilitem a emergência da cooperação; e se aproxima do neofuncionalismo ao dar ênfase à interdependência e às instituições internacionais como fatores que contribuem para o estabelecimento de relações mais cooperativas e pacíficas.

De acordo com a teoria institucionalista, a interdependência implica a existência de interesses mútuos que somente podem ser plenamente satisfeitos mediante a cooperação entre os Estados. Esta corrente descreve as relações entre os Estados no final do século XX como sendo caracterizadas por uma "interdependência complexa" (KEOHANE e NYE, 1988) que gera estímulos para a cooperação. A interdependência complexa possui, segundo os autores que cunharam a expressão, três características principais: (1) A existência de múltiplos canais conectando as sociedades, nos planos interestatais, transgovernamentais e transnacionais; (2) a agenda das relações entre os Estados consiste de muitos temas que não se arranjam de qualquer forma hierárquica ${ }^{4}$, e a linha que separa os assuntos de ordem externa e interna se torna por vezes tênue; (3) em muitas das interações entre os Estados o uso da força é um recurso inútil para a conquista de determinados objetivos, e por isso nem sempre é a

\footnotetext{
${ }^{4}$ Neste ponto o institucionalismo desafia diretamente a suposição realista de que as questões militares ou de alta política ocupam uma posição de destaque na agenda internacional, ficando os demais temas em segundo plano.
} 
estratégia adequada para os Estados. Em situações de interdependência complexa o emprego da força militar é pouco provável.

Uma vez que o recurso da força pode não ser eficaz em diversas circunstâncias e que os temas da agenda internacional não estão arranjados em uma ordem definida de importância, a distribuição do poder em cada área temática torna-se mais relevante, e os resultados das barganhas políticas tendem a variar de acordo com o assunto em pauta. Estes elementos que, segundo os autores institucionalistas, caracterizam as relações entre os Estados no mundo contemporâneo, contribuiriam para o estabelecimento de relações mais cooperativas e menos conflituosas.

Contudo, embora a interdependência e a existência de interesses mútuos sejam um estímulo para a cooperação, elas constituem condições necessárias mas não suficientes para a emergência de relações cooperativas. Dada a descentralização e as incertezas do sistema internacional, o diferente acesso que os Estados possuem à informação, e a busca individual de cada Estado pela realização de seus interesses, são necessários mecanismos que facilitem a superação dos problemas de ação coletiva enfrentados pelos Estados. De acordo com esta teoria, estes mecanismos seriam as instituições internacionais:

\footnotetext{
Especialmente quando a incerteza é grande e os atores têm diferentes acessos à informação, os impedimentos para uma ação coletiva e os cálculos estratégicos podem impedir a consecução de seus interesses mútuos. A pura existência de interesses comuns não é suficiente: também devem existir instituições que reduzam a incerteza e limitem as assimetrias de informação. (KEOHANE, 1988, p. 26).
}

Daí a importância das instituições. Sempre que haja interesses mútuos pode haver cooperação, mas o grau em que essa cooperação será exercida dependerá da existência e efetividade das instituições. São elas que possibilitam aos atores comprometer-se em acordos mutuamente benéficos. As instituições - entendidas como "conjuntos de regras (formais e informais) persistentes e conectadas, que prescrevem papéis de conduta, restringem a atividade e configuram as expectativas" (KEOHANE, 1993, p. 16-17) - diminuem as assimetrias de informação; facilitam as negociações; regulam e tornam mais previsível o comportamento dos Estados; facilitam o controle das atividades de uns Estados pelos demais. 
Tudo isso reduz as incertezas, tornando a criação de regimes e instituições atraente para os Estados.

Os regimes e instituições internacionais, portanto, afetam o fluxo de informação e as oportunidades de negociação entre os Estados; a capacidade de monitoração dos Estados por parte dos demais com relação à submissão aos acordos, o que influi sobre a credibilidade dos compromissos assumidos; e as expectativas com relação à solidez dos acordos. Desse modo, “as variações na institucionalização da política mundial exercem efeito significativo no comportamento dos governos" (idem, pág. 14).

Ao contrário do neo-realismo, cuja interpretação é a de que os regimes e instituições internacionais somente são efetivos quando amparados por uma grande potência com capacidade para tal, o institucionalismo argumenta que os regimes e instituições internacionais possuem uma dinâmica própria, e influem efetivamente sobre os cálculos dos atores para a determinação de suas estratégias, sendo, portanto, elementos relevantes do sistema internacional. KRASNER argumenta que um Estado poderoso pode ser um fator importante no momento de criação de um regime, mas que, uma vez criado, o regime em questão adquire autonomia e passa a exercer influência sobre o comportamento estatal, atuando como variável interveniente:

\footnotetext{
De acordo com a estrutura desta análise, não precisa haver congruência sempre entre as distribuições de poder e resultados e comportamentos relacionados. Uma mudança nas distribuições de poder nem sempre implica uma mudança nos resultados porque os regimes podem funcionar como variáveis intervenientes. Os regimes podem assumir vida própria, uma vida independente dos fatores causais básicos que resultaram na sua criação em um primeiro momento. [...] Os princípios, normas, regras e procedimentos podem não se adequar à preferência dos Estados mais poderosos (1982, p. 499).
}

Ao defender que as instituições e regimes internacionais gozam de relativa autonomia, KRASNER argumenta que os regimes adquirem uma espécie de inércia, e que as distribuições de poder tendem a mudar com muito mais freqüência que os regimes. A estabilidade relativa dos regimes deve-se, de acordo com KRASNER, a diversos fatores. Em primeiro lugar, ao ritmo da atividade diária, que gera hábitos que tendem a se perpetuar. Em segundo lugar, devido às incertezas do sistema internacional, que reforçam a tendência à durabilidade dos regimes de duas maneiras: (1) dado que a duração de uma dada distribuição 
de poder é incerta, podendo ser longa ou curta, seria custoso alterar os regimes a cada mudança na distribuição de poder; (2) os atores podem preferir continuar com as normas, princípios e procedimentos em vigor, ainda que eles não sejam plenamente satisfatórios, a empreender uma nova configuração cujos resultados não podem ser antecipados com precisão. Além disso, uma vez que um regime está estabelecido e em funcionamento, sempre haverá dúvidas quanto à aceitação e o funcionamento de um novo regime. Um terceiro fator ainda contribuiria para a estabilidade dos regimes: mesmo que haja atores insatisfeitos com um regime existente, muitas vezes estes atores são incapazes, do ponto de vista cognitivo, de formular uma estrutura alternativa.

Os regimes também desencadeiam, segundo KRASNER, um mecanismo de realimentação, ou seja, uma vez que princípios, normas, regras e procedimentos de tomada de decisão estejam estabelecidos, eles podem alterar os interesses egoístas e a as configurações de poder que levaram à sua criação.

\begin{abstract}
Uma vez que os regimes tenham sido estabelecidos, eles podem alimentar as variáveis causais básicas que os impulsionaram num primeiro momento. Eles podem alterar a distribuição de poder. Podem mudar as avaliações de interesses. Os regimes podem se tornar variáveis interativas, e não apenas intervenientes. [...] Uma vez que o regime esteja realmente em funcionamento, ele pode desenvolver uma dinâmica própria que pode alterar não apenas os resultados e comportamentos a ele relacionados como também as variáveis causais básicas (1982, p. 500).
\end{abstract}

Os regimes podem alterar os cálculos de interesse dos Estados porque alteram os custos, os incentivos e as oportunidades de ação. Os regimes também podem mudar os próprios interesses estatais, porque proporcionam o aumento dos fluxos de transação, geram informação, facilitam o conhecimento e a compreensão dos nexos dos relacionamentos entre Estados e criam direitos de propriedade.

Ainda, os regimes podem se tornar uma fonte de poder para Estados com capacidades nacionais limitadas que a eles recorrem. Nesse sentido, os recursos destes atores não são em si alterados, mas a sua capacidade para influenciar o comportamento dos demais é reforçada pelos princípios, normas, regras e procedimentos de tomada de decisão do regime. Krasner sugere mais: segundo o autor, os regimes podem alterar as próprias capacidades de 
poder dos Estados, porque incentivando determinados padrões de comportamento os regimes podem reforçar ou enfraquecer os recursos de determinados atores.

Estimulados pela interdependência e pela existência de interesses mútuos e amparados pelas instituições internacionais na superação dos problemas de ação coletiva, os Estados estabeleceriam relações cooperativas a fim de solucionar problemas que não poderiam ser resolvidos individualmente e obter ganhos maiores do que aqueles que seriam obtidos mediante a atuação individual. Dessa forma, a cooperação entre os Estados é um produto de um cálculo racional destes atores, isto é, os atores cooperam porque dessa forma obtêm ganhos que deixariam de conquistar caso adotassem estratégias alternativas.

O institucionalismo enfatiza os aspectos econômicos dos blocos regionais, destacando que a relação comercial entre os Estados gera incentivos e oportunidades para a cooperação interestatal, e que os ganhos obtidos mediante a cooperação são maiores em relação aos ganhos obtidos pela ação individual de cada Estado. De acordo com esta corrente de pensamento, a anarquia do sistema internacional e a preocupação com ganhos relativos não impedem que, buscando cada qual seus próprios interesses, os Estados se envolvam em acordos cooperativos e o resultado seja a obtenção de ganhos superiores àqueles que poderiam ser obtidos na ausência de cooperação.

Já o abandono dos acordos regionais implicaria altos custos para os Estados, sendo uma alternativa pouco atraente. Assim, uma vez posto em marcha, o processo integrativo tenderia a reforçar os incentivos por mais cooperação.

A intensificação das relações comerciais e o aumento da interdependência proporcionados pelos processos de integração regional inibiriam as disputas militares entre os Estados membros, uma vez que o conflito aberto implicaria a perda dos ganhos obtidos a partir das relações econômicas institucionalizadas. Por essa razão as relações entre os Estados de um agrupamento regional tendem a ser mais e mais pacíficas. 


\section{4 - CONSIDERaÇões Finais}

As teorias das relações internacionais aqui consideradas têm em comum entre si a suposição de que os Estados são entes racionais com interesses, objetivos e percepções, que atuam na perseguição de seus interesses e objetivos. Elas divergem, contudo, em relação às possibilidades de estabelecimento de relações cooperativas entre os Estados, a forma como se dá tal cooperação, os incentivos e as barreiras para a cooperação e os resultados das ações cooperativas.

A interpretação realista sugere que relações cooperativas são instáveis e só ocorrem esporadicamente por motivações estratégias. As características do sistema internacional impediriam o estabelecimento de relações cooperativas estáveis e duradouras. Dessa forma, a criação de arranjos econômicos regionais teria como causa o interesse dos Estados envolvidos em projetar ou consolidar poder regional e aumentar seu poder de barganha frente a terceiros países ou blocos. Sua permanência não é provável caso os interesses se alterem e caso os atores envolvidos avaliem que estão sofrendo perdas relativas.

Segundo o neofuncionalismo, são tarefas e problemas técnicos que estão além da atuação estatal que motivam a cooperação entre Estados, e, uma vez iniciada a cooperação, a tendência é que a necessidade de mais cooperação se expanda, num processo crescente de spillover. Uma vez colocado em marcha, um processo cooperativo tende a aumentar e se reforçar por meio de mais cooperação e de instituições. Os arranjos econômicos regionais seriam um exemplo de como os Estados interagem cooperativamente para solucionar problemas comuns, e tenderiam a elevar cada vez mais os níveis de cooperação entre os Estados envolvidos.

Já para o institucionalismo as instituições são o mecanismo por meio do qual é possível superar os problemas de ação coletiva, dadas as características do sistema internacional. Elas exerceriam funções que facilitam a emergência da cooperação, sobretudo quando há interdependência entre os Estados, e ajudariam a conferir maior previsibilidade e estabilidade no comportamento entre os Estados. As instituições desempenhariam papéis, em suma, que possibilitariam a emergência da cooperação ainda que os Estados sejam motivados 
por interesses particulares. Os Estados conquistariam ganhos que seriam impossíveis de serem obtidos sem cooperação com os Estados, por isso são motivados a aderir às instituições.

De acordo com as interpretações neofuncionalista e institucionalista, uma vez criadas, as instituições tendem a ter estabilidade. Os Estados possuem incentivos para manter sua adesão às instituições e podem incorrer em sérias perdas caso abram mão da cooperação. Já para o realismo, as instituições são instáveis, podendo erodir a qualquer momento, e os únicos incentivos que os Estados possuem para aderir às instituições e nelas permanecer são os ganhos assim obtidos, mas, tão logo julguem que deixaram de obter ganhos, ou que outros Estados estão auferindo ganhos relativamente maiores, os Estados não possuem quaisquer motivos para permanecerem nas instituições. 


\section{Capítulo 2 - A Política Externa Brasileira e as Divergências com a Argentina}

Os interesses que moveram Argentina e Brasil na constituição do Mercosul nunca foram idênticos. Por um lado, a Argentina era motivada sobretudo por perspectivas de ganho comercial com o acesso ao mercado brasileiro e por considerações políticas domésticas. Já o Brasil vislumbrava ganhos estratégicos, com a ampliação de sua projeção no âmbito internacional. As motivações distintas não constituíram um empecilho no momento da constituição do bloco. Ao contrário, foi possível compatibilizar as expectativas e erigir um acordo que acomodasse os interesses de ambos os países e também dos países menores.

É comum que, em decorrência de seus diferentes níveis de desenvolvimento, história, cultura, etc., os países envolvidos em um acordo de integração possuam percepções e interesses diferentes. Os diferentes objetivos internacionais e percepções dos Estados não impedem a construção de um arranjo de integração que compatibilize tais diferenças ${ }^{5}$. Nas palavras de OLIVEIRA e SENNES (2001), "arranjos regionais podem conviver com essa diversidade e, ainda assim, serem racionais e duráveis" (p. 89). Neste estudo partimos do pressuposto de que, ao menos no início do processo de integração, embora os interesses dos dois principais integrantes do Mercosul fossem distintos, estes puderam ser compatibilizados.

Com o passar do tempo, entretanto, algumas das agendas dos países envolvidos foram sendo frustradas, e o Mercosul se deparou com algumas das dificuldades normalmente enfrentadas pelos parceiros de um acordo de integração regional: as questões em torno da harmonização de políticas; o tratamento das barreiras não-tarifárias; o caráter e o grau de autonomia das instituições; as assimetrias entre os países envolvidos. Tais fatores, inicialmente tratados num clima de cooperação e aprofundamento flexível, foram se tornando pontos de discórdia de difícil compatibilização com o correr do tempo. Os temas foram se politizando e gerando impasses que atravancaram o processo de integração.

\footnotetext{
${ }^{5}$ Esta é uma interpretação sincrônica da integração regional. Uma interpretação mais irrealista, diacrônica, supõe que os objetivos e percepções dos atores envolvidos são homogêneos, e quando se alteram isso ocorre de forma homogênea entre os participantes ao longo do tempo.
} 
A queda dos fluxos comerciais intra-regionais a partir de 1999 veio reforçar a percepção de estagnação. Se num primeiro momento a existência de interesses diferentes, porém compatíveis, possibilitou que o Mercosul fosse erguido, surtindo efeitos importantes do ponto de vista comercial e aumentando a interdependência entre os Estados membros, a dificuldade de resolução de diversas questões ao longo do processo revelou divergências de interesses e percepções difíceis de serem conciliadas.

A hipótese deste estudo é a de que o Brasil vem adotando, em relação ao Mercosul, uma postura essencialmente estratégica, postura esta que converge com a interpretação neo-realista do comportamento dos atores estatais. Tal postura estratégica tem como centro de sua preocupação a consolidação de uma posição de liderança sub-regional e da imagem de potência média no cenário internacional, além da contraposição à hegemonia norte-americana na sub-região. Uma segunda hipótese complementar a esta é a de que tal postura, somada às distintas percepções e interesses nutridos pelos demais membros, principalmente a Argentina, em relação ao bloco, dificultou a composição de interesses e o aprofundamento da cooperação no âmbito do bloco.

Neste capítulo procuramos demonstrar que a atuação brasileira esteve, desde o momento de constituição do Mercosul, motivada pelo interesse de exacerbação do seu papel em relação aos países vizinhos, procurando projetar, no plano externo, uma imagem de líder regional e de média potência do sistema internacional, portanto de global player (ator global), bem como pelo desejo de barrar o avanço da proposta dos Estados Unidos para da constituição de uma Zona de Livre Comércio hemisférica, a ALCA (Área de Livre Comércio das Américas).

\section{1 - Breve histórico da política externa brasileira - De Rio Branco a Sarney (1902-1989)}

Desde a gestão do Barão de Rio Branco (1902-1912) a política externa brasileira vem sendo caracterizada por dois paradigmas básicos que a caracterizaram, em linhas gerais: o americanismo ou ocidentalismo e o globalismo ou universalismo. $\mathrm{O}$ 
paradigma americanista, tal como sugerido pela própria denominação, coloca os Estados Unidos como eixo central da política externa. De acordo com este paradigma, uma maior aproximação com a grande potência seria benéfica ao ampliar os recursos de poder do Brasil, aumentando seu poder de barganha frente a terceiros países. Já o globalismo supõe que a diversificação das relações exteriores é que constitui uma condição para o aumento do poder de negociação brasileiro, inclusive frente aos Estados Unidos.

Ao longo de todo o século XX a política externa brasileira oscilou entre os dois paradigmas. A atuação de Rio Branco inaugurou o paradigma americanista, cujo traço principal era uma íntima aproximação com os Estados Unidos. Aponta-se que neste período a política externa brasileira se deslocou de um eixo europeu para um eixo americano. A gestão de Rio Branco também marca o início de uma característica que é apontada como um traço contínuo da política externa brasileira: a relativa independência do Itamaraty na condução das relações exteriores do Brasil (CERVO e BUENO, 1992; LIMA, 2005). Dessa forma, a condução da política externa brasileira de 1902 a 1912 pode ser atribuída praticamente de maneira exclusiva ao Barão de Rio Branco (CERVO e BUENO, 1992), apesar do período abranger a administração de quatro presidentes: Rodrigues Alves, Afonso Pena, Nilo Peçanha e Hermes da Fonseca.

Não há consenso na literatura a respeito do período exato em que se deu uma ruptura com o americanismo introduzido pelo Barão de Rio Branco. De acordo com uma linha de interpretação, é nas gestões de Vargas e Kubitscheck, na década de 50, que são percebidos os primeiros traços de rompimento. Dessa forma, os governos de Vargas e Kubitscheck contariam como importantes antecedentes da política externa do período Quadros-Goulart (VIZENTINI, 1995 e 1998; CERVO, 1194 e 1998). Assim, a Política Externa Independente de Quadros e Goulart não teria constituído uma inovação na orientação da política externa brasileira, mais um aprofundamento das inovações lançadas por Vargas e Kubitscheck.

Interpretação diferente desta argumenta que foi no governo de Jânio Quadros que pela primeira vez foram adotados, em alguma medida, os princípios universalistas como alternativa em relação à aproximação com os Estados Unidos. Sob este ponto de vista, as administrações de Vargas e Kubitschek não teriam rompido com o paradigma americanista. 
Entre 1961 e 1964, durante os governos de Jânio Quadros e João Goulart, a política externa brasileira ficou conhecida como Política Externa Independente. A marca de "Independente" se justifica pela procura dos interesses do Brasil sem levar em consideração as questões ideológicas do conflito Leste-Oeste no contexto da Guerra Fria. A Política Externa Independente do período Quadros-Goulart

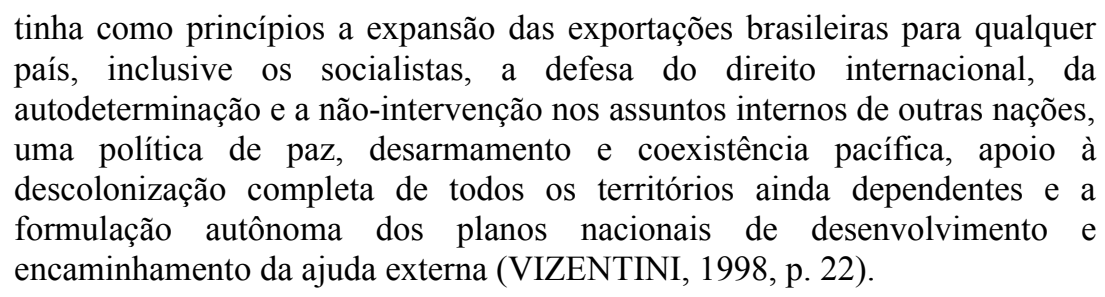

Com o golpe militar de 1964, entretanto, ocorreu uma retomada do paradigma americanista, com a tentativa de reaproximação junto aos Estados Unidos por Castelo Branco (1964-1967). A linha de política externa adotada no governo de Castelo Branco visava os interesses brasileiros em termos de comércio, tecnologia e capital, apostando na proximidade com a potência hemisférica como meio para atingir tais objetivos. A principal característica da política externa do governo Castelo Branco, portanto, foi a modelagem de um projeto estratégico centrado numa relação estreita com os Estados Unidos. Esse posicionamento caracterizou uma ruptura drástica com a Política Externa Independente do período QuadrosGoulart.

Os governos militares de Costa e Silva e Médici, que seguiram ao de Castelo Branco permaneceram enxergando a diplomacia como um instrumento do expansionismo econômico, de acordo com o perfil desenvolvimentista deste período, porém com mais autonomia em relação aos Estados Unidos do que o governo Castelo Branco.

A partir de 1967 os contatos do Brasil com o mundo foram sendo intensificados. A busca pelo desenvolvimento e o pragmatismo faziam com que o Brasil buscasse as melhores ofertas em termos de comércio, serviços, fluxos de capitais, ciência e tecnologia, onde quer que elas estivessem. Assim, paulatinamente as relações com os Estados Unidos foram progressivamente perdendo a importância. 
O governo Costa e Silva (1967-1969) passou a confrontar Washington em alguns pontos, retomando a busca por uma maior autonomia e pelo desenvolvimento. A chamada Diplomacia da Prosperidade de Costa e Silva tinha como principais objetivos a ampliação e diversificação dos mercados, além de preços melhores e mais estáveis para os produtos nacionais. Também era central o tema tecnologia e a atração de capitais, visando o desenvolvimento do país.

Médici (1969-1974), que sucedeu a Costa e Silva, procurou estabelecer com os Estados Unidas uma relação a meio caminho entre as posturas dos dois governos anteriores; o Brasil deveria continuar fazendo da política externa um instrumento para o desenvolvimento do país e a buscar as oportunidades onde quer que elas estivessem, porém evitando os atritos com a potência hemisférica. A política externa de Médici é conhecida como Brasil Grande Potência.

Dessa forma, logo após o governo Castelo Branco houve uma retomada progressiva da busca por uma maior autonomia, com um distanciamento contínuo, embora não dramático em relação ao Estados Unidos. É no chamado Pragmatismo Responsável do governo Geisel (1974-1979) que ocorrem mudanças mais drásticas, sendo possível identificar uma nova estratégia de inserção internacional para o Brasil, com a busca da ampliação e diversificação das relações exteriores do país.

De acordo com FONSECA JR., o Pragmatismo Responsável de Geisel e a Política Externa Independente de Quadros/Goulart possuem afinidades que se fundam "no desejo de autonomia e em algumas de suas expressões doutrinárias” (1998, p. 303). Em ambos os casos, o objetivo diplomático de ampliação da autonomia do país é claramente identificável. A experiência de Geisel, contudo, alcança maior concretude em função das próprias condições do país:

[...] ao longo dos anos se alteram as próprias condições de liberdade das potências médias no sistema internacional, como também de certa maneira o Brasil passará a ser, mais caracteristicamente, uma potência média. [...] Uma coisa é, por exemplo, a vontade de ampliar o intercâmbio com os países em desenvolvimento, outra é dispor de meios concretos que permitam que tal aconteça (idem). 
Ainda de acordo com este autor, a atuação da diplomacia brasileira durante a Guerra Fria se caracteriza pela "autonomia pela distância", o que significa, segundo FONSECA JR., que "admitíamos um alinhamento quanto aos valores fundamentais [do Bloco Ocidental], mas não o transformávamos em engajamento estratégico automático", além de “manter uma atitude crítica em relação às grandes potências" (p. 362).

Geisel promoveu uma política externa mais ousada, com a intensificação das relações do Brasil com a Europa Ocidental e o Japão e um afastamento mais determinado em relação aos Estados Unidos. Conforme é possível perceber, essa política já possuía alguns antecedentes nos governos militares que o precederam, mas "a grande diferença era a existência no governo Geisel de um projeto de autonomização econômica do país”, uma vez que "foi ele que entrou em choque com o poder norte-americano. As desavenças com os norte-americanos que, no período Médici haviam se situado em áreas de baixo impacto, assumiram envergadura por tocarem em questões conflitivas como a energia atômica" (CERVO, 1998, p. 204). Assim, é no governo Geisel que se situa um giro importante da política externa brasileira, com a adoção de um perfil de busca por uma maior autonomia que iria se manter por um longo período.

De Geisel a Sarney a política externa brasileira é caracterizada pela "autonomia pela distância” em relação aos Estados Unidos (FONSECA JR. 1998). A negação da idéia de uma aliança ou relacionamento preferencial com os Estados Unidos e o estreitamento das relações com outros países desenvolvidos e com países do Terceiro Mundo marcaram a atuação diplomática brasileira de Geisel até 1989. A ampliação da cooperação Sul-Sul, sobretudo com os demais países da América do Sul e com a África Meridional tornou-se um elemento importante da atuação diplomática brasileira. O Brasil passou a dirigir suas exportações de produtos manufaturados para o mercado latino-americano, lançou a iniciativa de criação do Tratado de Cooperação Amazônica e procurou solucionar suas divergências com a Argentina em torno do aproveitamento hidrelétrico da Bacia do Prata, fato que marcou a superação dos desentendimentos históricos entre os dois países ${ }^{6}$.

O estabelecimento de relações mais cooperativas com a Argentina, tanto no campo político quanto no campo econômico, foi um traço importante da política externa brasileira durante o período de redemocratização. A estruturação de um programa de

\footnotetext{
${ }^{6}$ Ver na próxima seção as páginas 44-46.
} 
integração econômica com o país vizinho que desembocaria na criação do Mercosul foi um dos temas mais dinâmicos da política externa brasileira durante o governo Sarney, com uma intensa produção de acordos bilaterais, conforme será visto na próxima seção.

\section{2 - Antecedentes do Mercosul}

Nos anos 80 América Latina vinha sofrendo importantes processos, como a recente onda de redemocratização, crises fiscais e de endividamento externo e o esgotamento do modelo de substituição de importações. Ao final da década os países da região iniciaram ajustes aos parâmetros econômicos neoliberais, com destaque para o México, o Chile e a Argentina (CERVO, 2001; GONÇALVES et. al., 1998; LIMA e HIRST, 1994). A criação do Mercosul, no início da década de 90, faz parte dos esforços dos países da sub-região para buscar sua reinserção no plano mundial depois da "década perdida".

Anteriormente a América Latina havia assistido a experiências de integração regional que obtiveram pouco ou nenhum sucesso. A primeira delas ocorreu em 1960, quando se procurou implementar a Associação Latino-Americana de Livre-Comércio (ALALC). A idéia da ALALC surgiu a partir de um trabalho prévio dos governos da Argentina, Brasil, Chile e Uruguai e dos estudos feitos pela Comissão Econômica para a América Latina (CEPAL), da Organização das Nações Unidas, por ocasião da primeira Reunião de Consulta sobre Política Comercial no Sul do continente. O Tratado de Montevidéu, que estabeleceu a ALALC, foi firmado em 18 de fevereiro de 1960 e entrou em vigor em 10 de junho de 1961, subscrito pela Argentina, Bolívia, Brasil, Colômbia, Chile, Equador, México, Paraguai, Peru, Uruguai e Venezuela.

O Tratado de Montevidéu estabelecia uma Zona de Livre Comércio, mas a meta final era a criação de um mercado comum latino-americano, conforme disposto em seu artigo $\mathrm{n}^{0}$ 54. O projeto, contudo, não obteve êxito nem mesmo em sua etapa inicial, de liberalização de comércio, devido a diversos fatores. Em primeiro lugar, o propósito da 
liberalização comercial era incompatível com o modelo de desenvolvimento amplamente utilizado na época pelos países latino-americanos, voltado para dentro e baseado na política de substituição de importações. A rigidez dos mecanismos estabelecidos para a liberalização comercial também representou um entrave para o sucesso da ALALC. Havia uma cláusula que obrigava um país a estender a todos os países da ALALC preferências concedidas a um país-membro da associação, o que acabou por inibir a produção de acordos. Também havia a instabilidade política da região, que maculava a credibilidade dos acordos que pudessem ser produzidos. Finalmente, havia a ausência de complementaridade entre as economias da região.

Diante do insucesso da ALALC, os países latino-americanos criaram, em meados da década de 1970, o Sistema Econômico Latino-Americano (SELA), em que voltaram a deliberar sobre os rumos da integração na região, e em 1980, foi criada a Associação Latino-Americana de Integração (ALADI).

A ALADI foi criada por um novo Tratado de Montevidéu, de 12 de agosto de 1980, firmado pelos mesmos países signatários da ALALC. O Tratado de Montevidéu de 1980 estabelece o objetivo de continuar com o processo de integração iniciado com a ALALC, porém de forma mais gradual e progressiva. O novo Tratado não determina prazos e compromissos quantitativos pré-estabelecidos. Trata-se, portanto, um arranjo bastante flexível, mais programático que normativo.

O Tratado da ALADI fornece o aparato jurídico para que seus membros concretizem acordos de integração bilaterais ou sub-regionais, tendo sido extinta a obrigatoriedade de extensão automática das preferências tarifárias acordadas a todos os membros da Associação, o que viabilizou o surgimento de esquemas sub-regionais de integração. Desse modo, já em 1980 foram firmados dois acordos bilaterais de complementação econômica no âmbito da ALADI que contam como importantes antecedentes do Mercosul: o Protocolo de Expansão do Comércio (PEC), entre Brasil e Uruguai, e o Convênio Argentino-Uruguaio de Complementação Econômica (CAUCE).

O Brasil e a Argentina até então mantinham um histórico de distância, quando não de rivalidade. Durante boa parte da sua história o Brasil e a Argentina disputaram entre si a supremacia sub-regional. A Bacia do Prata já havia sido palco de conflitos entre Espanha e 
Portugal durante o período colonial, e, após as independências, permaneceu oferecendo pauta para divergências entre os dois países.

Hoje o peso econômico brasileiro é bastante superior ao argentino, mas nem sempre foi assim. Ainda no século XIX, logo após a conquista de sua independência, a Argentina conquistou uma prosperidade econômica que a situava como país mais desenvolvido da sub-região, prosperidade esta baseada na exportação de produtos agropastoris para o mercado externo. No mesmo período o Brasil vivia uma fase de recessão e instabilidade econômica, bem como a crise da monarquia. A economia argetina era mais forte e mais dinâmica que a brasileira.

Ao longo do século XX, contudo, a situação dos dois países se inverteu. De acordo com MELLO (1996), “em 1930 a economia argentina era o dobro da brasileira; meio século depois a economia brasileira tornara-se o quádruplo da argentina" (p. 31). A partir da década de 30 o Brasil sofreu importantes processos de urbanização e industrialização, além de ampliar sua pauta de exportações e diversificar o espectro das suas relações diplomáticas. Dessa forma, alcançou uma condição econômica que o lançou à condição de maior economia da sub-região, comparável na América Latina apenas à economia mexicana, que passou por processos semelhantes.

Os atritos entre Brasil e Argentina também era percebido nas diferentes posturas dos dois países em termos de suas relações exteriores. Durante a maior parte do século XX os dois países mantiveram políticas exteriores divergentes. Enquanto a Argentina manteve durante a Guerra Fria uma posição de país não-alinhado, o Brasil buscava consolidar um espaço no mundo ocidental, e durante boa parte do período manteve uma posição próEstados Unidos.

As divergências e a busca da supremacia regional resultavam num clima de animosidade entre os dois países, que culminou nas perspectivas de confrontação nos anos 70 . O momento de maior tensão ocorreu em 1973, quando o Brasil assinou o Tratado de Itaipu com o Paraguai, visando o aproveitamento do potencial hidrelétrico do Rio Paraná. De acordo com MELLO, 
de colisão com a diplomacia argentina de 'convivência no pluralismo ideológico' colocada em prática pelo governo Lanusse com o escopo de contrabalançar a projeção do Brasil no subcontinente (1996, p. 15-16).

O ápice da discórdia foi a construção da usina hidrelétrica binacional de Itaipu a uma distância de $17 \mathrm{~km}$ da fronteira argentina, próximo ao local onde esse país pretendia construir, também em parceria com o Paraguai, uma outra usina hidrelétrica, com o adicional risco de um completo alinhamento do Paraguai - Estado amortizador das tensões entre Brasil e Argentina - à política brasileira, ameaçando o equilíbrio geopolítico então existente na região. O conflito foi dirimido com a assinatura, em 1979, de um Acordo Tripartite por Argentina, Brasil e Paraguai. Esse acordo possibilitou a acomodação de interesses ao viabilizar a construção da usina de Corpus por Argentina e Paraguai a $200 \mathrm{~km}$ de Itaipu. A assinatura do Acordo proporcionou a normalização do relacionamento brasileiro-argentino e a retomada da cooperação bilateral no começo da década de $1980^{7}$.

A aproximação econômica entre os dois países ocorreu em 1985, a partir da assinatura da Declaração de Iguaçu, documento que expressava a intenção de promover e acelerar o processo de integração econômica bilateral. Ainda em 1985 foi assinada a Declaração Conjunta Sobre Política Nuclear, documento que afirma os propósitos pacíficos dos programas nucleares desenvolvidos no Brasil e na Argentina e a decisão de intensificar a cooperação nesse campo. Este documento seria seguido por outros nos anos seguintes versando sobre o mesmo tema, e é representativo do ponto de vista da superação das tensões entre os dois países.

Também na área econômica seguiu-se uma produção de acordos bastante intensa $^{8}$. Em 1986 foi firmada a Ata de Integração Brasileiro-Argentina, que estabeleceu os princípios fundamentais do Programa de Integração e Cooperação Econômica (PICE). Em 1988 foi firmado o Tratado de Integração, Cooperação e Desenvolvimento, cujo objetivo era constituir um espaço econômico comum por meio da liberalização do comércio recíproco. Pode-se dizer que com o estabelecimento desse programa o Mercosul estava em fase de gestação. Não havia ainda, contudo, a definição de qual seria a profundidade da integração. Além disso, não estava definido se haveria e quais seriam os demais sócios do projeto. Além

\footnotetext{
${ }^{7}$ A respeito do conflito em torno de Itaipu ver MELLO (1996) e CAUBET (1991).

${ }^{8}$ Uma apresentação dos acordos bilaterais entre Brasil e Argentina a partir da década de 80 pode ser encontrada em ARNAUD (1996).
} 
da Ata, os Ministros das Relações Exteriores do Brasil e da Argentina assinaram um Acordo de Alcance Parcial de Complementação Econômica entre os dois países.

Em 6 de abril de 1988, em Brasília, os presidentes da Argentina, do Brasil e do Uruguai assinaram a Ata de Alvorada, Decisão Tripartite $n^{\circ} 1$, que previa a incorporação do Uruguai à integração bilateral argentino-brasileira. Dois anos mais tarde, em 6 de julho de 1990, os presidentes do Brasil e da Argentina assinaram a ata de Buenos Aires, documento em que afirmam a decisão de "estabelecer um mercado comum entre a República Argentina e a República Federativa do Brasil, o qual deverá encontrar-se definitivamente conformado em 31 de dezembro de 1994". Estava criado o Grupo Mercado Comum, ainda de caráter binacional (embora o Uruguai já tivesse iniciado sua aproximação com os dois países).

Logo o Ministro das Relações Exteriores do Paraguai, Aléxis Frutos Vaesken, também manifestou aos governos brasileiro e argentino o interesse de seu país em aderir aos acordos sobre a criação de um mercado comum. Nos dias 5 e 6 de setembro de 1990, os sócios do Grupo Mercado Comum - Brasil e Argentina - se reuniram em Buenos Aires com as delegações do Paraguai e Uruguai, concordando com a criação de um mercado comum quadripartite. O novo arranjo teria como base as disposições contidas na Ata de Buenos Aires, o documento que havia estabelecido o arranjo bilateral. Paraguai e Uruguai consentiram, portanto, com a manutenção de um arcabouço que já havia sido definido por Brasil e Argentina.

O processo de acordos e negociações para levar a cabo o projeto de um mercado comum regional culminou com a assinatura, em Assunção, no Paraguai, em 26 de março de 1991, do Tratado de Assunção. Tendo sido ratificado pelos quatro Estados-partes, o Tratado de Assunção entrou em vigor em 29 de novembro de 1991, criando o Mercosul. O bloco foi incorporado à ALADI como Acordo de Complementação Econômica (ACE) nº 18 .

O recrudescimento das tensões entre Brasil e Argentina e a aproximação econômica entre os países da sub-região ocorreu paralelamente ao o processo de redemocratização destes países e à mudança da estratégia econômica por eles adotada. Os países do Cone Sul romperam com o modelo de desenvolvimento que vinha sendo empregado pelos regimes autoritários - a política de substituição de importações - e passaram a buscar 
sua reinserção na economia mundial, tendo em vista o cenário de globalização, adotando estratégias de crescimento voltadas para fora, depois de décadas de isolacionismo.

Desse modo, o novo regionalismo pôde ser constituído em novas bases, diferentes daquelas que estavam presentes nas anteriores e quase sempre fracassadas tentativas de integração regional. Mais uma vez sob a influência da CEPAL, foi definido um novo tipo de regionalismo nos anos 90, que tem como objetivo a inserção das economias latino-americanas nos movimentos de comércio e investimentos internacionais. Trata-se do conceito de "regionalismo aberto", que implica

(...) fazer da integração um alicerce que favoreça uma economia internacional mais aberta e transparente, em vez de ela se converter num obstáculo que a impeça, com isso restringindo as opções ao âmbito dos países da América Latino e Caribe. Isso significa que os acordos de integração devem tender a eliminar as barreiras aplicáveis à maior parte do comércio de produtos e serviços entre os signatários, no contexto de suas políticas de liberalização em relação a terceiros, ao mesmo tempo em que é favorecida adesão de novos membros aos acordos (CEPAL, 1994, p.945).

Os efeitos esperados do regionalismo aberto são uma crescente interdependência econômica em nível regional, ao mesmo tempo em que se busca manter uma economia internacional aberta (GONÇALVES et. al., 1998, pp. 93-94).

A criação do Mercosul também ocorre em meio a algumas inovações da política externa brasileira, conforme será visto a seguir.

2.3 - A POLÍTICA EXTERNA BRASILEIRA NOS ANOS 90 E AS INTEGRAÇÕES HEMISFÉRICA E REGIONAL

A aproximação econômica com a Argentina e o estreitamento dos vínculos não só com este país, mas também com outros países do entorno regional foi uma característica marcante da política externa brasileira na década de 80. Conforme vimos acima, desde o governo Geisel a política externa brasileira vinha se pautando pela busca de maior autonomia, 
evitando um alinhamento automático com os Estados Unidos. A aproximação com os vizinhos latino-americanos fazia parte desta estratégia.

Com a ascensão de Collor ao poder, em 1990, contudo, houve uma ruptura com o perfil de política externa que vinha sendo adotado nos governos anteriores. O governo Collor promoveu uma retomada aos princípios mais americanistas, e buscou eliminar os pontos de atritos e as divergências com os Estados Unidos, procurando resgatar a credibilidade do país junto à grande potência. Nos governos anteriores os dois países haviam acumulado divergências em torno de questões como liberalização comercial, propriedade intelectual, controle nuclear e meio ambiente. A reaproximação com a grande potência tornou-se um item prioritário para a política externa brasileira no início do governo Collor, embora o relacionamento com os países do entorno regional não tenha se tornado um ponto irrelevante.

No plano comercial foram adotadas medidas de cunho neoliberal, talvez o traço mais marcante da administração Collor, com a introdução de um programa de redução tarifária, a eliminação de barreiras não-tarifárias e a reestruturação de um programa de incentivos à exportação.

De acordo com CAMPOS MELLO (2000), as mudanças introduzidas na política externa brasileira foram promovidas diretamente pelo presidente Collor, à margem da atuação do Itamaraty, fato incomum na história diplomática brasileira. Em seu segundo ano de mandato Collor teria se afastado dos assuntos internacionais, possibilitando uma atuação mais autônoma e dinâmica do Itamaraty, que então procurou dar continuidade ao processo de integração bilateral com a Argentina, voltando a lhe conferir prioridade e permitindo os avanços para a constituição do Mercosul. Com o afastamento de Collor das questões internacionais, o Itamaraty teria buscado reintroduzir elementos do paradigma globalista:

No contexto das tendências internacionais à formação de blocos econômicos e particularmente das negociações do NAFTA a integração sub-regional constituiria uma ação positiva na atuação internacional do país, que em alguma medida poderia atenuar suas diretrizes exclusivamente voltadas para os países desenvolvidos, especialmente para os Estados Unidos, introduzindo alguma dimensão Sul-Sul num quadro essencialmente Norte-Norte (pp. 9596). 
Além de representar uma possibilidade de atuação internacional alternativa ao relacionamento com os países desenvolvidos, a integração sub-regional também significava a possibilidade de uma atuação conjunta nas negociações a serem travadas com estes países. Em especial, representava uma possibilidade de atuação conjunta em relação às negociações com os Estados Unidos no que diz respeito à Iniciativa para as Américas, anunciada pelo presidente George Bush, em junho de 1990.

A Iniciativa para as Américas consistia na proposta de criação de uma área de livre comércio abrangendo todo o continente americano, à exceção de Cuba, e foi anunciada no mesmo momento em que negociadores do Brasil e da Argentina preparavam, em Buenos Aires, o acordo bilateral de integração econômica que seria assinado pelos dois países e que posteriormente seria expandido ao Paraguai e Uruguai, dando origem ao Mercosul.

Diante da proposta norte-americana o Itamaraty passou a ter a preocupação de concretizar rapidamente as negociações do Mercosul, bem como de configurar o bloco subregional como um acordo que fosse além de uma simples Zona de Livre Comércio. Os esforços brasileiros foram no sentido de que o Mercosul fosse criado já com as bases para a constituição de uma União Aduaneira. Dessa maneira, caso a Zona de Livre Comércio hemisférica se concretizasse, o Mercosul não seria diluído, mas permaneceria em razão de uma aproximação econômica mais profunda que a de uma ZLC .

Já do lado argentino havia um questionamento com relação à conveniência do projeto do Mercosul. A Argentina vislumbrava a possibilidade de aderir ao NAFTA, hesitando quanto a qual seria a melhor estratégia para o desenvolvimento e a inserção internacional do país. Depois de debaterem o assunto, os ministros das relações exteriores do Brasil e da Argentina concordaram que a Iniciativa para as Américas não deveria representar o fim dos esquemas de integração e complementação econômica em curso na região, e inclusive assinaram um comunicado conjunto expressando tal convicção. A Argentina, contudo, não pretendia fechar as portas para outras possibilidades de integração além do Mercosul.

A estratégia de atuação conjunta em relação à Iniciativa para as Américas se confirmou: os membros do Mercosul apresentaram uma posição conjunta diante da proposta

\footnotetext{
${ }^{9}$ Vide Introdução, página 10.
} 
norte-americana, e os cinco países assinaram o Rose Garden Agreement, conhecido como 4+1, em junho de 1991. Este foi o primeiro acordo firmando em conjunto pelos quatro países do Mercosul, assinado poucos dias após a assinatura do Tratado de Assunção.

Apesar do acordo conjunto, o Brasil e a Argentina não tinham posições idênticas quanto ao projeto de integração hemisférica. Em virtude de sua estratégia de inserção internacional, a Argentina manteve uma postura mais favorável que a brasileira em relação à Iniciativa para as Américas. Para este país seria natural que a integração hemisférica ocorresse mais cedo ou mais tarde. Já o Brasil empenhou-se para que o Mercosul não se transformasse num embrião da futura integração hemisférica. A diplomacia brasileira esforçou-se para que o Mercosul não se restringisse a uma Zona de Livre Comércio. Em 1992, ano seguinte à criação do Mercosul, a delegação brasileira apresentou aos demais membros do bloco o Cronograma de Las Leñas, um programa estabelecendo prazos para o cumprimento de tarefas que possibilitariam a entrada em vigor da união aduaneira no prazo previsto, isto é, em $1^{\circ}$ de janeiro de 1995. O empenho brasileiro foi bem sucedido e a União Aduaneira entrou em vigor no prazo previsto.

Na gestão de Itamar Franco (1992-1994), que chegou à presidência após o impeachment do presidente Collor, foi ocorrendo uma retomada dos objetivos de autonomia, diversificação e universalismo da política externa brasileira. Junto a esta retomada ocorreu uma maior incorporação dos novos temas da agenda internacional, como meio ambiente, direitos humanos, o controle de tecnologias sensíveis e as questões econômicas encaminhadas em fóruns multilaterais.

O Brasil passou a exercitar a "autonomia pela participação", uma autonomia que já não se pauta pela "distância" em relação à influência das grandes potências, mas pela participação ativa na comunidade internacional, mantendo a independência necessária porém sem evitar temas potencialmente polêmicos:

A autonomia, hoje, não significa mais "distância" dos temas polêmicos para resguardar o país de alinhamentos indesejáveis. Ao contrário, a autonomia se traduz por "participação", por um desejo de influenciar a agenda aberta com valores que exprimem tradição diplomática e capacidade de ver os rumos da ordem internacional com olhos próprios, com perspectivas originais (FONSECA JR., 1998, p. 368). 
Na nova estratégia, a adesão a organismos multilaterais e o regionalismo são elementos de central importância. O Brasil passou a ter uma visão mais positiva dos regimes internacionais, e muitas vezes conferiu sua adesão a eles, como no caso do Tratado de NãoProliferação Nuclear, tema sobre o qual o Brasil durante muito tempo defendeu o princípio da não-intervenção. O desejo de "participação" também significa um desejo de reconhecimento por parte da comunidade internacional de que o Brasil ocupa uma posição de relativa grandeza no sistema, participando ativamente de fóruns internacionais.

Durante o governo Itamar Franco, o Brasil lançou propostas condizentes com a pretensão do reconhecimento de potência média e de líder regional. Em dezembro de 1992 o presidente Itamar Franco lançou a Iniciativa Amazônica, uma proposta de negociação de acordos de complementação econômica nos parâmetros fornecidos pela ALADI entre os membros do Tratado de Cooperação Amazônica (Bolívia, Colômbia, Equador, Guiana, Peru, Suriname e Venezuela). E em 1993 a proposta da Iniciativa Amazônica foi seguida pela proposta da ALCSA (Área de Livre Comércio Sul-Americana), uma tentativa de expandir a influência brasileira para todos os países da América do Sul e uma proposta de integração que pretendia se colocar como uma alternativa para estes países em relação à integração hemisférica proposta pelos Estados Unidos.

A maior participação em organismos multilaterais e o lançamento de propostas regionais indicam o desejo brasileiro de exercer uma liderança regional efetiva, de mostrar à comunidade internacional que o Brasil exerce uma influência importante em seu entorno regional, se envolve nas questões regionais e mundiais e é capaz de exercer um papel mais ativo na comunidade internacional. O Brasil procura se afirmar como global player.

Sob este ponto de vista, a proposta de integração hemisférica lançada pelos Estados Unidos não era interessante aos interesses brasileiros. A proposta vinha sendo conduzida em bases que não agradavam à diplomacia brasileira. Os Estados Unidos tinham preferência por uma negociação de tipo "early harvest", caso a caso, e uma agenda focalizada na liberalização de serviços, propriedade intelectual, meio ambiente e compras governamentais. O Brasil considerava uma melhor estratégia a negociação em bloco, e desejava o tratamento de temas como os subsídios agrícolas e as normas andidumping. 
VEIGA (2004) sintetiza a estratégia brasileira nas negociações da ALCA em dois objetivos básicos:

- O objetivo de separar a dinâmica das negociações do país com outros países sul-americanos daquela que se aplica às relações com Estados Unidos, o que expressaria a prioridade das negociações na sub-região para o Brasil e viabilizaria o fortalecimento do "bloco sul-americano" nas negociações com o Norte; e

- A busca de uma configuração do acordo que preserve a autonomia nacional na regulação de temas considerados pertinentes para a formulação e implementação de políticas industriais: investimentos, compras governamentais, etc. (p. 14).

A tentativa de conter a ampliação da influência norte-americana em seu entorno regional também fica clara no tratamento diferenciado que o Brasil passou a dar aos países da América do Sul em detrimento dos países latino-americanos mais sujeitos à influência dos Estados Unidos. A América do Sul passou a ocupar uma posição de centralidade na política externa brasileira a partir dos governos Itamar Franco e Fernando Henrique Cardoso. Ao mesmo tempo, o México e os países da América Central, mais sujeitos à influência hegemônica norte-americana, foram perdendo uma parcela do espaço que ocupavam nas diretrizes da política externa brasileira, o que pode ser comprovado pelos esforços no sentido da obtenção de acordos cada vez mais produzidos exclusivamente visando os países da América do Sul, bem como na substituição da expressão "América Latina" por "América do Sul" em muitos dos discursos dos presidentes e ministros das relações exteriores do Brasil (CAMPOS MELLO, 2000).

O afastamento dos países latino-americanos mais próximos das esfera de influência dos Estados Unidos do campo da atuação da política externa brasileira, bem como uma diferenciação no tratamento com os países da América do Sul foi registrado na afirmação de LAFER:

[...] nesta virada do século a economia da geografia aconselha a um novo enfoque para o conceito de América Latina. De fato, há de ter em conta que o México, em função de sua participação no NAFTA e a América Central e o Caribe, por obra da atuação centrípeta da economia norte-americana, viram o seu grau de interdependência com o Norte aumentar ainda mais significativamente nos últimos anos. Por esse motivo, o futuro dessa parte da América Latina está cada vez mais vinculado ao que acontece nos Estados Unidos. A América do Sul, em contraste, tem relações regionais e internacionais mais diversificadas, tanto no plano econômico quanto no 
político. Este é um dado da realidade contemporânea que lhe confere uma especificidade própria no contexto da América Latina, da qual cabe extrair as apropriadas conseqüências em matéria de política externa (2001, p. 55)

Contudo, ao mesmo tempo em que procurava contrapor o Mercosul e a ALCSA ao projeto de integração hemisférica, o Brasil evitou, durante a gestão de Itamar Franco, e posteriormente Fernando Henrique Cardoso, uma relação conflituosa com os Estados Unidos. Algumas atitudes brasileiras procuravam estabelecer uma agenda positiva com este país, como a assinatura de acordos de não-proliferação nuclear e a adoção de medidas de liberalização comercial.

Além do cuidado para evitar conflitos diretos com os Estados Unidos, outro traço de continuidade do governo de Fernando Henrique Cardoso (1994-2002) na política externa brasileira foi a busca do reconhecimento parte da comunidade internacional de que é o Brasil é uma potência média. Diversas atitudes são tomadas nesse sentido, inclusive com o lançamento de sua candidatura para ocupar um assento permanente no Conselho de Segurança da ONU e os conseqüentes esforços para que a reforma do Conselho seja efetivada.

Neste contexto o Mercosul constitui uma plataforma de inserção no plano mundial. A experiência do bloco até então demonstrava que o mercado sul-americano poderia se transformar num destino importante para as exportações brasileiras de produtos manufaturados. Isso sem dúvidas era interessante ao Brasil. Mas, mais do que isso, ao Brasil interessava transmitir ao mundo a idéia de que exercia uma liderança regional, liderança esta que lhe dava condições de ocupar o assento que pleiteava no Conselho de Segurança.

Ao final de 1994, ao mesmo tempo em que o Mercosul encerrava o período de transição, ocorria a Cúpula de Miami, em que foi relançada pelos Estados Unidos o projeto de integração hemisférica que viria a ficar conhecido como ALCA. Os documentos finais da reunião estipulavam o ano de 2005 para a conclusão das negociações da Área de Livre Comércio das Américas, e afirmavam que o processo de liberalização ocorreria a partir dos acordos bilaterais e sub-regionais já existentes.

O empenho brasileiro na criação do Mercosul, em 1991, e em seu aprofundamento, em 1994, esteve motivado sobretudo por interesses estratégicos: por um lado procurava-se agregar os demais países sul-americanos sob a liderança brasileira; por 
outro lado, aumentar o poder o poder de negociação em relação à integração hemisférica. Ao longo deste período o Brasil adotou um posicionamento bastante flexível em relação às exigências feitas pela Argentina, fazendo concessões no que diz respeito à balança comercial e ao acesso ao seu mercado, bem como na tolerância de exceções à Tarifa Externa Comum, que impedem a plena conformação da União Aduaneira. Esta tendência reflete a observação de JAGUARIBE (2000):

Sendo o interesse brasileiro pelo sistema predominantemente político, enquanto o argentino é predominantemente econômico, tal fato suscita a tendência de o Brasil ser mais complacente com as demandas econômicas da Argentina, em troca do apoio político desta, do que reciprocamente a Argentina para com os interesses econômicos brasileiros (p. 37).

Na segunda metade da década de 90, contudo, o Brasil passou a adotar uma postura menos flexível, o que gerou o aumento de impasses no bloco. No plano retórico, o Mercosul nunca deixou de constituir uma prioridade da política externa brasileira. Na prática, contudo, após a implementação da União Aduaneira os avanços registrados no processo de integração foram irrelevantes, e o relacionamento entre Brasil e Argentina tornou-se cada vez mais pontuado por desentendimentos.

A falta de disposição brasileira em permanecer com uma postura flexível em relação às exigências dos parceiros do Mercosul na segunda metade dos anos 90 coincidiu com o esfriamento das negociações da ALCA. O poder executivo dos Estados Unidos não obteve do Congresso a autorização conhecida como fast track ${ }^{10}$ para conduzir as negociações da área de livre comércio hemisférica, o que enfraqueceu seu poder de pressão sobre os países latino-americanos. O próprio NAFTA entrou em vigor em 1994 após uma votação bastante apertada no Congresso norte-americano (232 e 202 votos). Parecia improvável que o Congresso dos Estados Unidos concordaria com a integração de seu país a economias de menor magnitude, e as perspectivas para a implementação da ALCA foram se reduzindo.

Quando George W. Bush assumiu o governo dos Estados Unidos, após a administração Clinton (1992-2000), as negociações da ALCA esfriaram ainda mais, dadas as prioridades do novo governo. Internamente, Bush precisava resolver o problema da

\footnotetext{
${ }^{10} \mathrm{O}$ fast track é uma autorização concedida pelo Congresso ao Executivo dos Estados Unidos para que este possa negociar um acordo internacional, sendo que os termos do acordo em questão não podem ser alterados posteriormente pelo Congresso, devendo este apenas aprová-lo ou rejeitá-lo em um prazo máximo de 90 dias.
} 
legitimidade de seu governo, contestada em função da desconfiança de fraude na contagem dos votos populares nas eleições. Externamente, a partir dos atentados de 11 de setembro os temas relacionados à segurança passaram a ocupar a prioridade da política externa norteamericana, ficando os assuntos comerciais relegados a um segundo plano.

No Mercosul passou a ficar evidente a indisposição brasileira em dotar as instituições do bloco de qualquer autoridade supranacional, bem como em fazer determinadas concessões aos parceiros, que reivindicavam um maior equilíbrio nas condições de competição, o tratamento das questões pendentes relativas aos instrumentos de proteção comercial e de coordenação macroeconômica. Ao Brasil, o Mercosul interessava como plataforma para consolidar sua liderança regional e marcar posição diante da proposta norteamericana da ALCA. Interessava, pois, como elemento para reforçar sua autonomia de atuação internacional. Um aprofundamento das instituições do bloco, em direção à supranacionalidade, significaria, contudo, uma perda de autonomia frente às instituições regionais. Não era esse o desejo brasileiro. De acordo com o então Ministro das Relações Exteriores, Luiz Felipe LAMPREIA (1999),

\begin{abstract}
O Brasil não tem razão nenhuma para abrir mão de sua autonomia. Não conheço ninguém de responsabilidade, no Brasil, que pudesse aceitar a idéia de que o governo brasileiro subscrevesse um tratado no qual delegasse a uma pessoa ou a um colegiado, por mais qualificados que fossem, a capacidade de representar, negociar e impor normas para todos os Estados-membros do Mercosul.

Creio que seria absolutamente inaceitável, para o Congresso Nacional, para a opinião pública brasileira, para a imprensa brasileira, que houvesse uma renúncia de soberania brasileira desta magnitude (p. 305, Conferência realizada para os conselheiros do Centro Brasileiro de Relações Internacionais).
\end{abstract}

O Mercosul não deixou de ser apontado como um tema prioritário para as relações exteriores do Brasil na segunda metade da década de 90. Mas na prática a diplomacia brasileira não fez grandes esforços para eliminar os impasses e pontos de atrito que foram se multiplicando ao longo do tempo e deteriorando os compromissos do bloco. O esfriamento das negociações da ALCA repercutiu sobre a disposição brasileira em fazer concessões aos sócios do Mercosul.

Em maio de 1998 foi realizada uma nova Cúpula, em que os Estados Unidos procuraram relançar a proposta da ALCA, reacendendo no interior do Mercosul as discussões 
sobre o aprofundamento do bloco. A reunião, contudo, ocorreu em meio à descrença de que a ALCA poderia ser concretizada num futuro próximo, em razão da resistência do Congresso norte-americano em conceder o fast track ao Executivo. E o aprofundamento do Mercosul ficou restrito à retórica, sem que nenhuma medida de resultado prático fosse adotada nesse sentido.

$\mathrm{Na}$ prática, os conflitos intra-Mercosul se politizaram significativamente no final da década de 90. O fato que costuma ser apontado como o divisor de águas do Mercosul é a desvalorização do real promovida unilateralmente pelo Brasil, em 1999, sem qualquer consulta prévia aos outros membros do Mercosul. De fato, a partir de 1999 houve uma redução dramática do comércio intra-regional e um retrocesso da agenda de integração em determinados pontos, com a estagnação de outros.

O Mercosul e a América do Sul como um todo não perderam, na segunda metade da década de 90, sua importância estratégica para o Brasil. De fato, em 30 de agosto e $1^{\text {o }}$ de setembro de 2000 ocorreria em Brasília uma reunião inédita entre os presidentes da América o Sul, cujo tema foi o aprofundamento da cooperação no sub-continente, especialmente no que diz respeito à integração física e projetos de infra-estrutura.

Também em 2000, diante da crise experimentada pelo bloco, os quatro Estados membros lançaram uma iniciativa com o nome sugestivo de "Relançamento do Mercosul", com uma agenda de retomada do processo de integração. A única medida relevante que alcançou resultado prático, contudo, foi a adoção de um Tribunal Permanente de Revisão para o bloco, que entrou em vigor em 2003 e substitui o modelo anterior de solução de controvérsias, baseado exclusivamente na criação de tribunais ad hoc. A paralisia da agenda e a redução do comércio intra-regional continuaram a alimentar a sensação de crise e a confirmar a baixa institucionalidade do Mercosul.

\section{4 - A POlítica EXTerna do gOverno Lula}


Quando Lula e Kirchner foram eleitos no Brasil e na Argentina, respectivamente $^{11}$, havia uma grande expectativa de que o quadro de crise do Mercosul fosse revertido, e que ambos os governos se empenhassem na reconstrução da credibilidade do bloco. De fato, ao assumirem os governos, os presidentes dos dois países procuraram realçar em seus discursos a importância do Mercosul e a necessidade de retomar com vigor o processo de integração. Apesar da retórica, entretanto, nenhuma medida concreta foi adotada para solidificar os compromissos do bloco e retomar a agenda de aprofundamento da integração.

Ao contrário, por diversas vezes a Argentina anunciou a adoção de cotas máximas para a entrada de produtos brasileiros em território argentino, e em diversas ocasiões Kirchner deixou de comparecer a eventos no Brasil ou deixou o país antes do término das reuniões, transmitindo uma imagem de que o relacionamento entre os dois países ainda possui importantes pontos de atrito.

Desde que assumiu o governo, Lula tem visitado países em todos os continentes, e em diversas ocasiões as visitas resultaram na assinatura de acordos bilaterais. $\mathrm{O}$ presidente também tem participado de fóruns multilaterais como os ocorridos em Davos (G8), a reunião da UNCTAD, a Cúpula de Presidentes da América Ibérica e do Mercosul. Também foram reforçadas as ações para a obtenção de um assento permanente no Conselho de Segurança da ONU, com a adoção de determinadas atitudes congruentes com este objetivo, como o envio de tropas em representações da ONU ao Haiti, em 2004. O governo Lula, dessa forma, dá continuidade ao projeto de diversificar as relações do Brasil e consolidar a imagem de global player e de líder regional capaz de intervir e atuar em seu entorno regional e participar ativamente da comunidade internacional.

Ações como o apoio ao aprofundamento dos projetos de integração na América do Sul e uma atuação mais ativa em crises políticas em seu entorno regional revelam "uma maior disposição em criar condições em nível regional para sustentar um projeto de liderança política" (VILLA, 2005. p.18). Por outro lado, pretendendo atuar como um global player, o

\footnotetext{
${ }^{11}$ Ambos assumiram a presidência de seus países em 2003.
} 
Brasil também confere sua adesão e seu apoio a regimes internacionais, atuando, assim, em duas frentes:

[...] a diplomacia brasileira parece se pautar pela lógica da busca de ganhos absolutos no âmbito global - e para isto a cooperação intra-regional e internacional é enfatizada. Por outro lado, no entorno regional a lógica é a da busca de ganhos relativos, donde a resistência à criação de determinados mecanismos, como o Tribunal Judicial para o Mercosul, por exemplo, ou mesmo a resistência ao aprofundamento da institucionalização do Mercosul, do Grupo do Rio ou do G-12, procuraria preservar o diferencial de poder do país (PINHEIRO, 2000, p.324).

$\mathrm{Na}$ estratégia de diversificação e projeção da imagem de global player, o Mercosul permanece sendo um espaço para o exercício da desejada liderança regional, apesar da indisposição brasileira em fazer concessões nos campos comercial e institucional a partir de 1999. Essa indisposição permanece no governo Lula. Na verdade, o Brasil tem até cedido a algumas reivindicações argentinas, mas em campos que antes de fortalecer, enfraquecem a institucionalidade do bloco. É o caso do acordo aceito pelo Brasil de limitar as exportações da chamada linha branca (composta por eletrodomésticos como geladeiras, fogões, etc.) para a Argentina, que vai de encontro ao objetivo de liberalização comercial do Mercosul e foi produzido de maneira ad hoc, sem que mecanismos institucionais correspondentes tenham sido criados no âmbito do Mercosul.

A estratégia de contenção da ALCA tal como proposta pelos Estados Unidos também tem sido um dos pontos marcantes da política externa no governo Lula. Embora a administração anterior também tenha evitado a concretização do acordo tal como proposto, era notável a tentativa de evitar confrontos e a rejeição direta da proposta norte-americana. Durante a administração de Fernando Henrique Cardoso, o Brasil procurou conter o projeto da ALCA, porém evitando confrontar diretamente a diplomacia americana. Os discursos eram sempre cautelosos quando o assunto era a integração hemisférica. No governo Lula, a rejeição da proposta, tal como vem sendo feita pelo governo dos Estados Unidos, é mais explícita. Em entrevista concedida durante a campanha presidencial, LULA DA SILVA afirmou:

A nossa posição sobre a ALCA é muito conhecida. Desde o início, manifestamos nossa preocupação com os gravíssimos problemas que geraria para a região um acordo de livre comércio tal como foi proposto pelo governo dos Estados Unidos em 1994. Uma das principais razões para isso é 
a grande assimetria existente entre os países e a falta de recursos e políticas tendentes a eliminar as grandes desigualdades socioeconômicas entre as regiões e os países. Digo sempre que a proposta como está não significa integração, mas sim a anexação das economias latino-americanas à economia dos Estados Unidos (2003, p. 6).

Em 2003, na Reunião Ministerial de Miami, o Brasil conseguiu obter um acordo mais congruente com o interesse brasileiro, delineando-se um perfil de negociação que ficou conhecido como "ALCA light". Os termos do acordo definem que haverá um acordo básico sobre os temas da negociação da ALCA, com direitos e obrigações a serem compartilhados por todos os países. A partir deste acordo básico cada país poderá negociar bilateralmente os temas de seu interesse com os países que lhe sejam convenientes. A obtenção do acordo pode ser considerada uma conquista importante para o Brasil frente aos Estados Unidos.

De acordo com as suposições neo-realistas, o regionalismo tático emerge por questões defensivas em relação a ameaças vindas de fora e com o objetivo de aumentar o poder de barganha dos países envolvidos frente a terceiros atores. A política externa brasileira tem no Mercosul não apenas uma base para sustentar sua liderança sub-regional, mas, integrado a esta estratégia, um ponto de apoio para promover a contenção da influência norteamericana em seu entorno regional.

Na medida em que, com a obtenção do acordo conhecido com ALCA light e o esfriamento das negociações para a conformação da Zona de Livre Comércio hemisférica diminui a ameaça representada pela iniciativa norte-americana, diminui também em importância uma das motivações para o Brasil fazer concessões aos parceiros do Mercosul em nome da integração regional. Não queremos dizer com isto que o Mercosul tenha perdido todo o interesse estratégico para o Brasil, mas que, com o enfraquecimento de uma das motivações brasileiras, aumenta a indisposição do país em arcar com os custos de liderança do bloco. 
No final da década de 80 e início dos anos 90 a experiência comum de Brasil e Argentina em torno das mudanças no sistema internacional, redemocratização e esgotamento do modelo econômico baseado na substituição de importações foi um dos elementos que facilitou a conciliação dos interesses dos dois países, possibilitando o início da integração bilateral e posteriormente quadrilateral, ainda que os interesses não fossem idênticos. Havia, sim, interesses mútuos, não homogêneos.

Conforme exposto acima, o Brasil vinha adotando um perfil de política exterior calcado na busca pela autonomia e pelo universalismo, perfil que se mantém inclusive até o governo Lula, interrompido recentemente apenas durante o governo Collor. Já a Argentina passou a adotar, na década de 90, um comportamento internacional caracterizado mais pelo pragmatismo econômico do que pela preocupação com a sua situação relativa de poder.

Anteriormente a política de poder havia sido uma característica importante da política externa Argentina. Conforme exposto acima, a Argentina mantinha um histórico de disputa pela supremacia regional com o Brasil e divergências mais graves em torno de disputas territoriais com o Chile e com a Inglaterra. A partir do governo Menem, contudo, a política externa argentina passou a privilegiar as questões econômicas, e, adotando os princípios do chamado "realismo periférico", passou a buscar um relacionamento mais estreito com os Estados Unidos, a fim de resgatar sua credibilidade internacional, desgastada não apenas pelo processo de deterioração econômica que atingiu toda a América Latina nos anos 80 mas também pela Guerra das Malvinas.

De acordo com o "realismo periférico", teoria elaborada por Carlos Escudé, a Argentina deveria reconhecer sua situação de país periférico do sistema internacional e eliminar de sua política exterior os desentendimentos históricos com os Estados Unidos e seus aliados, além de cultivar um bom relacionamento com os países vizinhos, incluindo o Brasil. Reaproximando-se destes países, sobretudo dos Estados Unidos, a Argentina deveria oferecerlhes apoio político e buscar junto a eles a satisfação de seus interesses econômicos. A lógica 
desta estratégia é a de que, fornecendo apoio político, a Argentina obteria com mais facilidade a satisfação de seus interesses econômicos.

Além disso, manter uma boa relação tanto com o Brasil quanto com os Estados Unidos também seria uma estratégia benéfica à Argentina, na medida em que o relacionamento com um dos países representaria um equilíbrio na relação com o outro. De acordo com ESCUDÉ (1997), as alianças com o Brasil por um lado e os Estados Unidos por outro seriam "duas alianças complementares que se equilibram mutuamente, impondo-se limites uma à outra, ao mesmo tempo em que consolidam para a Argentina uma situação de relativa segurança no âmbito interestatal” (p. 6). Ainda de acordo com esse autor,

\begin{abstract}
A aliança com os Estados Unidos tem três funções: 1) eliminar os obstáculos ao desenvolvimento argentino gerados por décadas de confrontações políticas desnecessárias. 2)dissuadir o aventurismo potencial de alguns setores militares chilenos sem gastar dinheiro com armas e 3) por limites às expectativas brasileiras, já que a aliança argentina-norte-americana é um claro sinal de que não estamos dispostos a um confronto com os Estados Unidos por causa de utopias terceiro mundistas que não estejam relacionadas com os interesses diretos dos países do Mercosul [...].

Por sua vez, a aliança com o Brasil também tem três funções principais: 1) promover uma intensa integração econômica subregional; 2) por limites à aliança com os Estados Unidos, dando um claro sinal de que não temos que tolerar tentativas norte-americanas de intervir em assuntos internos brasileiros (por exemplo, com a justificativa de defender o sistema ecológico da Amazônia) e 3) contribuir também para dissuadir o aventurismo potencial de alguns setores militares chilenos (p. 6-7).
\end{abstract}

A estratégia da diplomacia Argentina nos fins da década de 80 e início da década de 90 também ficou conhecida como a estratégia de ser um "Estado normal". Ser um "Estado normal" significava

não só abrir mão do confronto político, ideológico e de segurança com os Estados Unidos e seus aliados, mas apoiá-los e, quiçá, segui-los em quaisquer iniciativas [...]. Significava, ademais, sujeitar a estrutura econômica interna e os padrões de inserção econômica internacional aos dogmas do chamado Consenso de Washington. Em conseqüência desse giro para a normalidade, a Argentina exibiu nos anos noventa uma política exterior pragmática e clara em seus princípios e objetivos, diferente da brasileira, feita de hesitações conceptuais e estratégicas (CERVO, 2001, pp. 280-281).

Depois de uma política externa caracterizada pelo isolamento, pelo desenvolvimentismo e por motivações na área de segurança que perdurou durante o regime 
militar (1976-1983), a Argentina adotou um paradigma claramente neoliberal, implementando reformas rápidas e radicais, com o interesse prioritário voltado para economia.

O governo Menem (1989-1999) herdara uma situação de hiperinflação e caos econômico. Restabelecer a estabilidade econômica do país era o principal objetivo do novo governo, que promoveu uma reforma neoliberal estruturada no Plano de Convertibilidade, elaborado pelo ministro Domingos Cavallo. Entre outras medidas, o Plano de Convertibilidade estabelecia um sistema de fixo de câmbio, com a paridade peso-dólar.

No plano internacional, o estabelecimento de uma aproximação estreita com os Estados Unidos, que chegou a ser descrita como "relações carnais" com este país, era a estratégia para o resgate da credibilidade internacional da Argentina. Constam como expressões da mudança do comportamento argentino em direção a um maior alinhamento com os Estados Unidos: o envio de tropas argentinas à Guerra do Golfo, liderada pelos Estados Unidos; o padrão de votação da Argentina na Assembléia da ONU, que passou a ser convergente com o padrão norte-americano; o apoio à intervenção dos Estados Unidos no Haiti; a retirada do Movimento dos Países Não-Alinhados; a ratificação dos Protocolos de Não-Proliferação Nuclear e de Tlatelolco; o cancelamento do projeto armamentista Cóndor II.

Além do estreitamento das relações com os Estados Unidos e o abandono do confronto político com outros países desenvolvidos, com destaque para a Grã-Bretanha, contra a qual a Argentina lutara pelas Ilhas Malvinas, podem ser identificados outros três eixos importantes de atuação da política externa argentina no início dos anos 90: a ênfase na satisfação dos objetivos de desenvolvimento econômico, com a conseqüente resistência em ceder em pontos que impliquem algum malefício econômico para a Argentina; o abandono da pretensão de ser um ator protagonista internacional e da postura hostil em relação a rivais históricos; e o apoio ao sistema de paz e segurança internacional estabelecido pela carta da ONU (BERNAL-MEZA, 2002).

Tais eixos da política externa argentina no governo Menem significaram uma ruptura drástica com a política anterior, sobretudo no que diz respeito a dois países em especial. Em primeiro lugar, conforme assinalado, com os Estados Unidos, devido ao abandono da postura de isolamento e a procura de relações privilegiadas com a grande potência. E em segundo lugar com o Brasil, não apenas no que diz respeito à busca da 
superação das divergências dos temas relacionados à segurança, mas também com relação à importância da relação comercial com o país vizinho.

O aprofundamento da integração econômica com o Brasil significava acesso ao grande mercado brasileiro, e uma possibilidade para melhorar a inserção internacional do país. Ao entrar em vigor, o Mercosul de fato proporcionou o aumento das exportações argentinas para o Brasil, o que contribui para a estabilização econômica argentina. A despeito disso, contudo, a Argentina apoiou prontamente a proposta norte-americana de 1990 de constituição de uma Zona de Livre Comércio hemisférica, a Iniciativa para as Américas. Apesar da importância comercial que o Mercosul adquiria para a Argentina, o principal interesse deste país era obter benefícios econômicos onde quer que eles pudessem ser buscados, além do bom relacionamento com os Estados Unidos e o reconhecimento por parte deste dos efeitos surtidos pelo plano de estabilização econômica.

Dessa forma, os dois principais sócios do Mercosul tinham percepções diferentes com relação à proposta da Zona de Livre Comércio hemisférica que mais tarde ficaria conhecida como ALCA. Para o Brasil, a proposta de integração hemisférica, tal como vinha sendo feita pelos Estados Unidos, não atendia aos interesses do país, e a integração subregional significava uma forma de ampliação do poder de barganha dos países sul-americanos na defesa de seus interesses e na contenção da ALCA, bem como uma plataforma para sustentar suas pretensões de exercer um papel de líder regional e de global player. Para a Argentina a ALCA significa uma oportunidade de aproximação com os Estados Unidos, obtendo daí não apenas reconhecimento político como possibilidades comerciais.

Também em relação ao Mercosul os dois países experimentavam percepções diferentes. Para a Argentina, o Mercosul significava apenas um dos movimentos de liberalização do país, não conflitante com a proposta hemisférica da ALCA. O Mercosul significava acesso ao grande mercado brasileiro, mas a Argentina não pretendia, com sua adesão ao bloco sub-regional, fechar as portas para seu relacionamento com os Estados Unidos. Pelo contrário, à Argentina interessava, sim, a manutenção de um relacionamento estreito com a grande potência. O Mercosul era parte da estratégia Argentina de liberalização comercial e reconquista de sua credibilidade internacional, jamais uma opção alternativa a acordos que pudessem ser produzidos com os Estados Unidos, como parecia ser para o Brasil. 
Nas palavras do embaixador argentino Jorge VEGAS (s/d., apud FREDERICO, 2001), “é a partir do Mercosul que a integração hemisférica deverá se potencializar". A observação também é feita por ONUKI:

Se para a Argentina o fortalecimento do Mercosul indicava claramente seu desejo de ingressar no NAFTA, para o Brasil a integração com seus vizinhos representava uma opção de consolidar sua posição de liderança na América do Sul (2002, p. 127).

A Argentina considerou seriamente seu ingresso ao NAFTA, o que estava de acordo com a estratégia de aproximação dos Estados Unidos, chegando a causar algum malestar no relacionamento com o Brasil. Mas a adesão ao acordo acabou sendo impossibilitada em função da negação por parte do Congresso dos Estados Unidos do fast track para que o Executivo pudesse conduzir as negociações.

Com o correr do tempo e a impossibilidade de adesão ao NAFTA, e diante do incremento comercial no âmbito do Mercosul, com a conseqüente interdependência de seus membros, além de um superávit comercial na balança bilateral com o Brasil favorável à Argentina, a importância do Mercosul e do relacionamento com o Brasil acabou adquirindo maior importância para a política externa argentina. Entretanto, até o final da década de 90 a Argentina seguia uma política de "double standing a respeito das relações econômicas hemisféricas: entre optar pela ALCA e aprofundar o Mercosul" (BERNAL-MEZA, 2002, p. 80), oscilando entre as duas iniciativas de integração.

Ao assumir o governo, em dezembro de 1999, De La Rúa sinalizou uma ruptura com alguns elementos do governo anterior, incluindo a importância relativa dada à integração sub-regional. O novo presidente manifestou a intenção de alçar o Mercosul à condição de interesse primordial do país com o simultâneo o abandono das "relações carnais" com os Estados Unidos. As ações do governo, contudo, transmitiam uma mensagem ambígua. A Argentina continuou evitando o confronto com os Estados Unidos e apoiando determinadas iniciativas deste país, ao mesmo tempo em que apoiava o Mercosul apenas da medida em que este atendesse fielmente às suas expectativas econômicas. Sempre que a liberalização comercial se mostrava desfavorável ao país, a Argentina prontamente reivindicava um tratamento diferencial para proteger sua economia ou ameaçava adotar medidas unilaterais 
para tal, transmitindo a idéia de que seus objetivos econômicos estavam acima de quaisquer outras considerações.

A ambigüidade também ficou expressa no posicionamento adotado pela Argentina em fóruns multilaterais. No ano de 2000, a Argentina votou pela punição de Cuba na Comissão de Direitos Humanos na ONU, numa posição aproximada à dos Estados Unidos, ao mesmo tempo em que na Cúpula de Brasília, realizada no mesmo ano, apoiou o governo constitucional da Colômbia e defendeu a política de não-intervenção em relação ao caso, desta vez em proximidade com a posição brasileira.

Enquanto De La Rúa e o ministro das relações exteriores Alberto Rodrígues Giavarini reafirmavam a importância do Mercosul para a Argentina, o ministro da Economia, Domingos Cavallo, autor do Plano de Convertibilidade para a estabilização econômica do país, freqüentemente dava declarações públicas expressando a inconveniência do Mercosul tal como vinha funcionando, defendendo que o bloco deveria retroceder a uma Zona de Livre Comércio.

Em artigo publicado no Brasil em 1999, Roberto Lavagna sintetizou os argumentos argentinos em favor de um Mercosul menos ambicioso, restrito a uma Zona de Livre Comércio. Lavagna afirma que, com uma ZLC, a Argentina garantiria o acesso irrestrito e discriminatório a um mercado mais de duas vezes maior que seu próprio mercado mantendo total autonomia e capacidade de determinar sua própria Tarifa Externa e a possibilidade de se aproximar dos Estados Unidos sem maiores constrangimentos. Lavagna segue afirmando que “o slogan poderia ser 'vendendo ao Brasil, seguindo os Estados Unidos'. E tudo isso sem ter que dar explicação alguma a um sócio "incômodo"” (p. 3). Isto é, a Argentina conciliaria o interesse comercial no Brasil com a aproximação estratégica com os Estados Unidos. Um Mercosul tal como está constituído atrapalha esta estratégia:

Tal como estão as coisas hoje, aceitar esta linha implicaria, no plano econômico, um viés para a especialização em bens primários e de baixo valor agregado, e, no plano internacional, praticar a política de "subordinar-se", já não mais à potência dominante global, mas uma subpotência regional. Francamente, fica difícil descobrir quais seriam as razões para estarmos dispostos a aceitar este estado de coisas.

$[\ldots]$

No aspecto político, "subordinação" por "subordinação", é melhor ter como referência a maior potência (p. 5). 
As palavras de Lavagna são representativas do mal-estar que se estabeleceu entre o Brasil e a Argentina, os dois maiores integrantes do Mercosul. Já em 1999, declarações como esta e a reversão do comércio intra-regional indicavam que o Mercosul experimentava uma crise. Lembremos que o bloco também acumulava uma grande quantidade de agenda não concluída, que ia da inclusão de todos os produtos no regime da ZLC à coordenação de políticas macroeconômicas, passando pelos mecanismos para a constituição plena de uma União Aduaneira.

Para minimizar os impactos da crise do Mercosul, em dezembro de 2000, na Cúpula de Florianópolis, os quatro países decidiram revisar o sistema de solução de controvérsias do bloco, um dos pontos da agenda de "Relançamento do Mercosul", que resultou na posterior adoção de um Tribunal Arbitral Permanente para resolver os conflitos comerciais, com a Assinatura do Protocolo de Olivos. Os quatro membros também decidiram reduzir em meio ponto a Tarifa Externa Comum e reiteraram a importância do bloco.

Contudo, já em 2001 o ministro Cavallo aumentou unilateralmente a tarifa externa argentina como parte do Plano de Convertibilidade, o que ocasionou sérios conflitos políticos com o Brasil. O presidente brasileiro Fernando Henrique Cardoso cancelou a visita que faria a Buenos Aires em abril de 2001 como uma demonstração do descontentamento em relação à medida do ministro Cavallo, que quebrava os compromissos assumidos no âmbito do Mercosul. Além do aumento unilateral da sua Tarifa, pouco tempo depois a Argentina também reduziu as tarifas de importação de 500 produtos de fora do Mercosul, em desrespeito à Tarifa Externa Comum.

Tais atritos vêm se somando nos últimos anos. É cada vez maior a agenda não concluída do bloco e, além disso, a reversão de acordos que já se encontravam estabelecidos. Diante de dificuldades econômicas e déficits comerciais com o Brasil em anos recentes, a Argentina vem pleiteando há anos a adoção de medidas para conter a entrada de produtos brasileiros no país, como no caso da linha branca, algumas vezes obtendo o consentimento brasileiro e em outras ferindo unilateralmente as normas da integração comercial.

Dessa forma, o Mercosul vem sendo enfraquecido por um sem-número de medidas unilaterais adotadas pelos Estados membros e pelo crescente acúmulo de agenda não-concluída. A politização dos conflitos, acentuada a partir de 1999, acabou por ser sentida 
também no fluxo de comércio intra-regional, que sofreu uma queda a partir deste período e nunca mais recuperou o dinamismo conquistado de 1991 a 1998, conforme veremos no próximo capítulo.

\section{6 - Considerações Finais}

Já no momento de constituição do Mercosul, o Brasil e a Argentina manifestavam percepções distintas e possuíam interesses diferentes em relação ao bloco. Desde o início a Argentina esteve motivada pelas possibilidades de ganhos econômicos que adviriam do acesso ao mercado brasileiro. O Brasil também foi motivado, desde o início, pela estratégia de consolidação de uma posição de líder regional e de global player.

Os diferentes interesses e percepções dos dois maiores membros do Mercosul não impediram que o acordo regional fosse erigido e obtivesse resultados satisfatórios em seus primeiros anos de funcionamento. Conforme apontamos acima, interesses diferentes não necessariamente significam interesses divergentes, e por isso a concretização do arranjo regional foi possível. Pode-se dizer que os interesses do Brasil e da Argentina, embora diferentes, eram interesses mútuos. Os dois países reconheciam a importância um do outro para seus respectivos interesses.

Durante o período de transição (1991-1994) o comércio intra-regional aumentou de maneira significativa e o empenho das diplomacias envolvidas possibilitou a concretização da agenda de liberalização comercial prevista no Tratado de Assunção. $\mathrm{O}$ aumento do comércio intra-regional parecia corresponder ao interesse argentino, ao passo que o Brasil empenhava-se em dotar o bloco de credibilidade e força, a fim de promover seus próprios interesses. Para tanto adotou um comportamento flexível frente às sensibilidades dos parceiros de integração, bem como se empenhou em consolidar a agenda dentro dos prazos previstos pelo Tratado de Assunção, inclusive com a apresentação do Cronograma de Las Leñas em 1992, logrando que o Mercosul alcançasse a condição de uma União Aduaneira ao 
término de 1994. Conforme exposto acima, o empenho brasileiro na constituição de uma UA esteve condicionado pela proposta de criação de uma Zona de Livre Comércio apresentada pelos Estados Unidos em 1990.

O comércio intra-regional continuou aumentado até 1998. Contudo, conforme a integração regional vai se aprofundando, alcançar o consenso entre todos os membros vai se tornando mais difícil. No caso do Mercosul, a agenda de liberalização comercial foi bem implementada nos estágios iniciais do processo de integração, mas outros temas, tais como a coordenação de políticas macroeconômicas e a criação de mecanismos institucionais de escape (salvaguardas) mostraram uma dificuldade maior de conciliação. Essa dificuldade somou-se a uma politização progressiva das diferenças de interesses entre os membros.

Com o correr do tempo, passou a ser difícil para a Argentina conciliar seu interesse de relacionamento comercial com Brasil com o interesse em estabelecer "relações carnais" com os Estados Unidos, uma vez que o Brasil pretendia justamente limitar a influência norte-americana em seu entorno regional, esforçando-se para que a integração hemisférica proposta pelos Estados Unidos não ocorresse nas bases desejas por este país e, caso visse a ocorrer, não "engolisse" o Mercosul, absorvendo-o num projeto regional de maiores proporções.

Os interesses de Brasil e Argentina foram se politizando, embora esteja claro que o Mercosul permanecia satisfazendo ao menos uma parcela dos interesses de ambos os países. Por isso o Mercosul não deixou nunca de ser enfatizado como uma prioridade nos discursos de política externa de representantes de ambos os países, embora vez por outra também aparecesse nos discursos uma vontade de manter o Mercosul limitado em seus propósitos comerciais - como quando Domingos Cavallo expressou o desejo de que o Mercosul ficasse restrito a uma Zona de Livre Comércio - e em sua autonomia institucional com o ministro Lampreia manifestando explicitamente a resistência brasileira em dotar as instituições do Mercosul de qualquer autoridade supranacional.

Mesmo com o comércio intra-regional em expansão, foram se ampliando os pontos de atrito entre o Brasil e a Argentina, e se num primeiro momento o Brasil mostrou-se flexível frente às necessidades dos seus parceiros regionais, com o passar do tempo a disposição brasileira em fazer concessões foi diminuindo. A capacidade de pressão norte- 
americana para a constituição da ALCA foi perdendo força e a adesão da Argentina ao NAFTA tornou-se bastante improvável. Isso contribuiu para que o Brasil adotasse uma postura mais rígida frente à reivindicações argentinas e dos sócios menores, resistindo, por exemplo, na adoção de mecanismos de salvaguarda para o bloco e de inovações institucionais.

A situação agravou-se a partir de 1999, com a desvalorização unilateral brasileira de sua moeda e a reversão do comércio intra-regional, ocasionando a adoção de medidas unilaterais também pela Argentina, visando a proteção de sua economia. Desde então o Mercosul acumula assuntos pendentes e sofre com o retrocesso de compromissos que já estavam estabelecidos. As tentativas de trazer novo ânimo ao processo de integração ficaram no plano retórico e das boas intenções, sem que resultados práticos tenham sido alcançados. Até mesmo a agenda de liberalização, que havia sido o âmbito de maior sucesso do bloco, corre o risco de um grave retrocesso, com a possibilidade de diminuição da abrangência da União Aduaneira e mesmo de retorno a uma Zona de Livre Comércio sendo aventada por setores de todos os países envolvidos. 
Capítulo 3 - Trajetória Institucional e Comercial do Mercosul

\section{$3.1-$ AsSimetrias}

Um elemento de caráter estrutural marca o processo de integração do Cone Sul: as assimetrias entre os países que conformam o bloco, notadamente o peso representado pelo Brasil. É certo que um arranjo de integração regional fatalmente envolverá países de diferentes tamanhos, níveis de desenvolvimento econômico e tecnológico, capacidades militares etc. Tais diferenças tendem a resultar em percepções distintas acerca da natureza do sistema internacional e em objetivos internacionais também diferenciados. Isso não quer dizer, entretanto, conforme destacado acima, que tais diferenças devem necessariamente impedir a emergência do processo de integração.

Contudo, cumpre lembrar que o Brasil possui uma magnitude muito superior a todos os demais membros do Mercosul em diversos quesitos, como território, população e PIB (Produto Interno Bruto). Com um PIB que corresponde a mais de dois terços do PIB total do Mercosul, o Brasil é o destino de grande parte das exportações da Argentina, do Paraguai e do Uruguai, mas exporta para estes países apenas uma pequena parte de sua produção. Com uma indústria mais dinâmica, o Brasil possui uma pauta e destinos de exportações bem mais diversificados que seus parceiros sub-regionais.

O PIB brasileiro corresponde a cerca de $70 \%$ do PIB total do Mercosul. Em 1992, quando deu sua menor contribuição, o PIB brasileiro representou $61,15 \%$ do PIB do bloco, e em 2002, quando deu sua maior contribuição, correspondeu a 79,35\%, ano em que, em função da crise econômica pela qual passava, a Argentina contribuiu com apenas 17,57\% do PIB do Mercosul.

A participação argentina no PIB do Mercosul praticamente corresponde aos outros 30\%, uma vez que o PIB do Paraguai e do Uruguai é bastante pequeno mesmo em 
relação ao PIB argentino. Em média, ao Paraguai tem correspondido menos de 1\% do PIB do Mercosul, e ao Uruguai algo entre 1 e $2 \%$.

Tabela 1: PIB do Mercosul em milhões de dólares correntes

\begin{tabular}{|c|c|c|c|c|c|c|c|c|c|c|}
\hline \multirow[b]{2}{*}{ Ano } & \multicolumn{2}{|c|}{ Argentina } & \multicolumn{2}{|c|}{ Brasil } & \multicolumn{2}{|c|}{ Paraguai } & \multicolumn{2}{|c|}{ Uruguai } & \multicolumn{2}{|c|}{ Mercosul } \\
\hline & Valor & $\%$ & Valor & $\%$ & Valor & $\%$ & Valor & $\%$ & Valor & $\%$ \\
\hline 1990 & 141,353 & 23,83 & 438,256 & 73,87 & 5,265 & 0,89 & 8,366 & 1,41 & 593,24 & 100 \\
\hline 1991 & 189,709 & 30,91 & 407,758 & 66,44 & 6,249 & 1,02 & 10,047 & 1,64 & 613,763 & 100 \\
\hline 1992 & 228,779 & 35,82 & 390,594 & 61,15 & 6,446 & 1,01 & 12,878 & 2,02 & 638,697 & 100 \\
\hline 1993 & 236,755 & 33,97 & 438,297 & 62,89 & 6,875 & 0,99 & 15,002 & 2,15 & 696,929 & 100 \\
\hline 1994 & 257,696 & 31,08 & 546,22 & 65,87 & 7,854 & 0,95 & 17,475 & 2,11 & 829,245 & 100 \\
\hline 1995 & 258,097 & 26,06 & 704,169 & 71,09 & 9,016 & 0,91 & 19,298 & 1,95 & 990,58 & 100 \\
\hline 1996 & 272,242 & 25,27 & 774,935 & 71,93 & 9,629 & 0,89 & 20,515 & 1,90 & 1077,321 & 100 \\
\hline 1997 & 293,006 & 25,88 & 807,746 & 71,35 & 9,612 & 0,85 & 21,704 & 1,92 & 1132,068 & 100 \\
\hline 1998 & 299,098 & 26,76 & 787,742 & 70,47 & 8,596 & 0,77 & 22,371 & 2,00 & 1117,807 & 100 \\
\hline 1999 & 283,664 & 33,41 & 536,633 & 63,21 & 7,741 & 0,91 & 20,913 & 2,46 & 848,951 & 100 \\
\hline 2000 & 284,346 & 31,11 & 601,732 & 65,84 & 7,722 & 0,84 & 20,086 & 2,20 & 913,886 & 100 \\
\hline 2001 & 268,831 & 33,49 & 508,433 & 63,34 & 6,848 & 0,85 & 18,561 & 2,31 & 802,673 & 100 \\
\hline 2002 & 102,042 & 17,57 & 460,838 & 79,35 & 5,594 & 0,96 & 12,277 & 2,11 & 580,751 & 100 \\
\hline 2003 & 129,596 & 19,86 & 505,732 & 77,50 & 6,04 & 0,93 & 11,191 & 1,71 & 652,559 & 100 \\
\hline 2004 & 153,014 & 19,97 & 593,091 & 77,39 & 7,029 & 0,92 & 13,215 & 1,72 & 766,349 & 100 \\
\hline
\end{tabular}

Fonte: Divisão de Estatísticas das Nações Unidas . Disponível na internet: http://unstats.um.org/unsd/. Resgatado em 2005.

Esta assimetria não apenas indica as diferenças econômicas existentes entre os quatro países membros, como também implicam um certo padrão no fluxo de comércio do bloco e diferentes percepções e interesses em relação ao sistema internacional. O Brasil possui maior autonomia em relação aos seus parceiros de integração, uma vez que apenas uma parcela relativamente pequena de suas exportações é destinada aos demais membros do Mercosul.

A dinâmica do comércio intra-regional será analisada a seguir, juntamente com a evolução institucional do bloco, examinando-se de forma periodizada o processo de integração regional do Mercosul.

3.2 - Período de Transição (1991-1994) 
O início da década de 90 foi marcado pela adoção de políticas econômicas de cunho neoliberal por parte dos governos latino-americanos, de maneira mais ou menos radical em cada país, e o novo projeto de integração regional foi concebido pelos países do Mercosul como um arranjo compatível com o processo de liberalização mais amplo, caracterizando assim a nova estratégia do regionalismo aberto.

O Tratado de Assunção dotou o bloco de uma estrutura institucional provisória para os primeiros anos de funcionamento do acordo de integração. O próprio Tratado de Assunção previa a criação de uma estrutura definitiva após um período de transição que se encerraria em 1994. Os principais órgãos criados pelo Tratado de Assunção são o Conselho Mercado Comum (CMC) e o Grupo Mercado Comum (GMC), sendo o primeiro o principal órgão do Mercosul, integrado pelos Ministros de Relações Exteriores e de Economia dos quatro países, e o único a produzir decisões, sempre por meio do consenso entre os Estados membros. O Grupo Mercado Comum ficou incumbido da função executiva, devendo adotar os mecanismos necessários para que as decisões do Conselho Mercado Comum sejam cumpridas. Este órgão é composto por quatro representantes de cada um dos Estados membros, vinculados ao Ministério de Relações Exteriores, ao Ministério de Economia e aos Bancos Centrais.

Também foi criada uma Comissão Parlamentar Conjunta (CPC), apenas de caráter consultivo, e Subgrupos de Trabalho (SGTs) subordinados ao GMC e encarregados da negociações de questões técnicas. A CPC é composta por 16 parlamentares de cada um dos sócios, e tem a incumbência de facilitar a internalização, em cada país, dos acordos produzidos no âmbito do Mercosul, bem como a harmonização das legislações dos países membros. A CPC não possui prerrogativas decisórias, podendo apenas encaminhar recomendações ao Grupo Mercado Comum. No interior dos Subgrupos de Trabalho inauguraram-se os canais de participação dos setores não-governamentais. Também os SGTs possuem um caráter exclusivamente consultivo, atuando por meio de recomendações ao GMC. 
Para a solução de controvérsias foi assinado em 17 de dezembro de 1991 o Protocolo de Brasília, em que os membros optaram não pela criação de um Tribunal de Justiça, mas sim por um sistema arbitral ad hoc, em que é criado um tribunal para casa caso, delimitado ao objeto de disputa, e que somente é colocado em prática no caso das negociações diretas, com a intervenção do GMC e do CMC, não serem capazes de solucionar a disputa.

A intergovernamentalidade e o sistema decisório baseado no consenso, em que cada um dos quatro países conserva um poder de veto sobre qualquer decisão, são as principais características da estrutura institucional inaugurada pelo Tratado de Assunção. A opção pelo consenso para a tomada de decisões é apontada como um ponto positivo por determinados autores, como FLORÊNCIO e ARAÚJO:

\begin{abstract}
O sistema do consenso funciona, no MERCOSUL, como uma força de agregação. É um sistema que leva à permanente busca do equilíbrio entre as particularidades individuais e o projeto coletivo: cada país vê-se o tempo todo obrigado a saber até que ponto pode ceder em seus interesses para permitir a formação do consenso e a partir de que ponto não pode ceder, mas deve impedir uma decisão que lhe desfavorece. A busca do consenso constitui, ao final, um exercício muito mais rico do que a votação pura e simples (1998, pp. 81-82).
\end{abstract}

Mas esse sistema também é criticado pela rigidez que confere ao processo de encaminhamento dos problemas; por colocar todos os países em condições de igualdade para a tomada de decisões, sem considerar suas diferenças em termos de seu peso econômico e demográfico relativo; e por gerar impasses sobre os temas mais controversos.

Com relação à intergovernamentalidade também surgem questões relativas à magnitude de cada país, pois argumenta-se que os países de maior peso relativo acabam exercendo pressão para que suas posições sejam adotadas, enquanto um sistema supranacional poderia minimizar este problema.

Do ponto de vista comercial, o Tratado de Assunção deu origem à Zona de Livre Comércio por meio de um programa automático de liberalização, que previa a uma redução de 7\% a cada semestre sobre as tarifas incidentes sobre os produtos comercializados no interior do bloco, partindo de uma redução inicial de 47\%. Para minimizar os efeitos da liberalização nos setores menos competitivos de cada país foram adotadas listas de exceções. 
Para sistematizar as tarefas mais importantes a serem cumpridas até 1994, e visando a concretização da agenda prevista pelo Tratado de Assunção, foi aprovado, em julho de 1992, o Cronograma de Las Leñas, uma proposta de periodização das tarefas a serem cumpridas para que a União Aduaneira pudesse ser inaugurada em 1995. Já nesse período foram observadas algumas questões em torno das quais não havia consenso, entre elas a liberalização dos setores automotivo e açucareiro, que permanecem à parte da liberalização ainda hoje. Nesse período também foi questionado se o bloco deveria mesmo avançar rumo a etapas mais profundas de integração ou permanecer exclusivamente como uma ZLC.

A despeito da falta de consenso sobre determinadas matérias, o programa de liberalização foi aplicado com sucesso, de modo geral, dentro dos prazos previstos, e em janeiro de 1994, em reunião realizada na cidade de Colônia, no Uruguai, os Estados Partes assinaram uma declaração conjunta em que reafirmavam o interesse e a necessidade de formalizar uma União Aduaneira, denotando o interesse em prosseguir com o processo de aprofundamento da integração. Foi definido, então, um período para a implementação gradual da União Aduaneira. Tal período iniciou-se em $1^{\circ}$ de janeiro de 1995 e terminaria em 31 de dezembro de 2001, mas vem sendo prorrogado em função da dificuldade em abranger todos os produtos e em terminar a plena equalização de tarifas.

Embora os países do bloco tenham expressado a intenção de iniciar a coordenação de políticas macroeconômicas e setoriais, isto não ocorreu. Nenhum avanço nesse item foi registrado durante o período de transição. Mas o programa de liberalização comercial surtiu importantes efeitos sobre os fluxos de comércio intra-regionais, que cresceram substancialmente.

Os acordos de liberalização entre os países que conformam um bloco regional têm o efeito de gerar uma zona de comércio preferencial entre os membros, fazendo aumentar o fluxo de comércio intra-zona em relação ao comércio praticado com terceiros países, aumentando, assim, a interdependência entre os países do bloco. $O$ aumento da interdependência pode ser avaliado pelo aumento do comércio intra-regional, isto é, o aumento das exportações entre os países membros, e pelo aumento da participação das exportações intra-regionais nos respectivos PIBs. 
Caso já existisse em 1990, um ano antes de realmente entrar em vigor, o Mercosul teria registrado um total de $8,86 \%$ de exportações intra-regionais em relação às exportações totais dos países que hoje compõem o bloco. Em 1995, ano esse índice já atingia 20,28\%. Estes dados revelam que os países membros deixaram de negociar com terceiros países uma parcela de suas exportações e importações em favor dos parceiros comerciais preferenciais do Mercosul, aumentado, assim, a interdependência entre eles (vide Tabela 2).

A participação das exportações intra-regionais no PIB da Argentina, que era de $1,04 \%$ em 1991, passou para 1,86\% em 1994. No caso brasileiro, a participação passou de 0,57\% em 1991 para 1,08\% em 1994. O Paraguai, menor sócio do bloco, passou a ter as exportações para os demais países do bloco como fonte de 12,47\% de seu PIB em 1994, enquanto em 1991 esta participação era de 7\% (Tabela 7).

Apesar da intensificação do comércio entre os dois países, a Argentina demonstrou um descontentamento em razão dos déficits comerciais bilaterais com o Brasil nos primeiros anos de funcionamento do bloco. Em função deste descontentamento do sócio argentino, o Brasil consentiu, em nome da continuidade do processo de integração, na elevação, por parte da Argentina, da taxa de estatística incidente sobre as importações de três para dez por cento, ao final de 1992. Além disso, o Brasil passou a importar mais petróleo e trigo do país vizinho, diminuindo o superávit brasileiro. Nos anos seguintes a balança bilateral passaria a ser favorável à Argentina durante a maior parte do tempo.

As concessões feitas pelo Brasil à Argentina são representativas da maior sensibilidade brasileira às necessidades dos parceiros de integração nos primeiros anos de funcionamento no Mercosul, conforme foi descrito no Capítulo 2. O período de transição foi marcado não apenas pelo forte incremento do comércio intra-regional, mas também pela conciliação de interesses brasileiros e argentinos. Neste período inicial do Mercosul a Argentina ainda mantinha um comportamento vacilante em relação ao bloco, dada a possibilidade de adesão ao NAFTA. Para assegurar a satisfação e o comprometimento argentino nas questões relativas ao Mercosul, o Brasil concordava em fazer concessões à Argentina no aspecto comercial, satisfazendo assim os interesses econômicos deste país. Havia também a Iniciativa para as Américas, outro incentivo externo para que o Brasil procurasse consolidar o comprometimento da Argentina com a integração regional. 
O período de transição constitui a fase do Mercosul em que mais ocorreu sinergia entre todos os fatores que favorecem o processo de integração regional: a existência de interesses mútuos que puderam ser compatibilizados para a criação do bloco; o cumprimento da agenda de integração; a intensificação da interdependência entre os Estados membros em razão do aumento dos fluxos comerciais intra-bloco e da importância do aumento desses fluxos na economia dos Estados. Nos períodos seguintes não seria possível, entretanto, manter todos estes fatores funcionando a contento.

\section{3 -União AduAneira (1995-1998)}

O Mercosul encerra o período de transição previsto pelo Tratado de Assunção e ingressa numa nova fase em 1995, quando entram em vigor a União Aduaneira, ainda que de funcionamento imperfeito ${ }^{12}$, e a estrutura institucional definitiva do bloco, delineada pelo Protocolo de Outro Preto, assinado pelos quatro presidentes em 17 de dezembro de 1994.

O debate que precedeu à assinatura do Protocolo de Ouro Preto evidenciou que os quatro países não tinham uma opinião uniforme sobre as questões de intergovernamentalidade, supranacionalidade e sistema decisório. A Argentina e principalmente o Brasil defendiam a substituição do sistema decisório, baseado no consenso, para um sistema que levasse em consideração o peso relativo de cada país, situação em que adquiririam maior autonomia em relação ao Paraguai e Uruguai, enquanto estes tinham interesse na manutenção do sistema vigente, a fim de conservar seu poder de veto. Já com relação à intergovernamentalidade, Brasil e Argentina é que pretendiam manter a estrutura existente, ao passo que Paraguai e Uruguai mostravam-se favoráveis à adoção de elementos de supranacionalidade, na suposição de que tais elementos poderiam relativizar o peso da Argentina e do Brasil (VIGEVANI et. al., 2002). Tais divergências resultam das assimetrias

\footnotetext{
${ }^{12}$ Conforme será visto adiante, a União Aduaneira entrou em vigor suportando um regime de adequação para diversos produtos. O regime de adequação previa que a Argentina, o Brasil e o Uruguai terminariam de uniformizar suas tarifas em 2001, e o Paraguai em 2006. Tais prazos, contudo, vem sendo prorrogados e em alguns casos houve suspensão unilateral das tarifas, contrariando os acordos realizados em 1994.
} 
entre os componentes do Mercosul, que repercutem sobre as percepções e os interesses de cada país.

Ao fim das negociações prevaleceram as características já presentes na estrutura criada pelo Tratado de Assunção, isto é, instituições intergovernamentais e sistema decisório baseado no consenso. Assim, Protocolo de Outro Preto introduziu poucas modificações nas instituições estabelecidas pelo Tratado de Assunção.

O Conselho Mercado Comum e o Grupo Mercado Comum foram mantidos com suas composições e atribuições originais. A Comissão Parlamentar Conjunta também permaneceu limitada em sua atuação, como órgão consultivo que pode emitir recomendações ao GMC. Uma Comissão de Comércio, que já vinha funcionando desde 1994, ficou encarregada de gerenciar os instrumentos da política comercial comum, cuidando para que a aplicação das medidas se faça corretamente e examinando solicitações nacionais relativas a casos comerciais específicos.

Foi criado um Fórum Consultivo Econômico e Social (FCES) com o intuito de congregar os representantes dos setores não governamentais (empresários, trabalhadores, entidades da sociedade civil) no debate de temas concernentes ao Mercosul. Este órgão também possui um caráter exclusivamente consultivo. Os Subgrupos de Trabalho foram mantidos como os principais órgãos de assessoria técnica do Grupo Mercado Comum, e o Protocolo de Ouro Preto ainda prevê que Reuniões Especializadas e Grupos ad hoc, bem como um Comitê de Cooperação Técnica para assessorar o Grupo Mercado Comum em suas decisões.

O Protocolo de Ouro Preto não introduziu mudanças dramáticas nas instituições do Mercosul. Embora os acordos de cunho comercial tenham permitido um avanço rumo a um maior nível de integração, com a inauguração da União Aduaneira, a estrutura institucional permaneceu praticamente inalterada. Entretanto, cumpre destacar que o aprofundamento comercial também sofria algumas dificuldades, com pontos de difícil negociação. Não foi possível estabelecer um acordo sobre a remoção de barreiras nãotarifárias, ou sobre coordenação macroeconômica, e a definição da Tarifa Externa Comum não foi tarefa fácil. 
As estruturas tarifárias nacionais eram, no início do processo negociador, bastante distintas. De modo geral, a Tarifa brasileira era bem mais alta que as Tarifas paraguaia e uruguaia, e um pouco mais alta que a Tarifa argentina. Os bens de capital e os setores de informática e telecomunicações foram percebidos por todos os países do bloco como os mais sensíveis para alteração da TEC, e por essa razão foram concedidos prazos mais extensos para a adequação destes produtos.

Além desses dois setores, foram permitidas listas de exceções nacionais, contemplando produtos específicos para cada país-membro. Cada um pôde escolher até 300 produtos para manter em regime de exceção até 2001. Note-se que os cronogramas de convergência já haviam sido definidos, e não poderiam ser alterados unilateralmente. O prazo mais extenso que havia sido fixado para a adequação se estendia até o ano de 2006, exclusivamente para o Paraguai, que deveria então aplicar a TEC aos produtos de sua lista de exceções que, ao contrário dos demais países, contemplava 399 produtos. Cabe lembrar que ainda permaneciam à parte do livre comércio o açúcar e os veículos automotores.

Embora tolerando um regime de adequação, a união aduaneira entrou em vigor em $1^{\circ}$ de janeiro de 1995, e o comércio intra-regional viveu sua maior fase de crescimento. Do momento da criação do bloco até 1998 a interdependência entre os sócios se aprofundou de maneira notável.

Com exceção do Uruguai, os países do bloco viram a participação das exportações intra-regionais no respectivo PIB mais que dobrar entre 1991 e 1998 (vide Tabela 7). As exportações intra-bloco, que representavam $8,86 \%$ das exportações totais dos países que compõem o bloco em 1990 passaram a representar 24,98\% deste total em 1998 (Tabela 2).

É importante notar que o vigor comercial do Mercosul na fase que vai de 1995 a 1998 não encontrou correspondência nos demais assuntos do bloco. Conforme assinalamos acima, no plano institucional não houve qualquer modificação relevante. Também não houve progresso em torno das barreiras não-tarifárias e da coordenação de políticas macroeconômicas. Logo após a entrega em vigor da TEC novas exceções foram autorizadas, e os prazos de equalização vêm sendo prorrogados. Embora crescesse a interdependência 
entre os países membros, tornava-se cada vez mais difícil a produção de novos acordos. Nas palavras de BOUZAS,

\begin{abstract}
No que diz respeito à performance do Mercosul, o período de 1995/1998 foi marcado por contrastes. De fato, esses foram os anos de aumento da interdependência e de crescimento da paralisia regulatória. Durante este período, a imagem prevalecente era a de que o Mercosul era tão bemsucedido que poderia progredir impulsionado tão-somente pelos interesses do setor privado, enquanto a agenda política ficava relegada a segundo plano. Como os eventos demonstram mais tarde, o Mercosul começou a acumular uma crescente quantidade de negócios pendentes (2001, p. 4).
\end{abstract}

Neste período ainda não haviam emergido pontos de atrito graves entre os Estados-partes, mas começava a ficar evidente que os sócios não possuíam preferências homogêneas ou de fácil conciliação. A disponibilidade brasileira em fazer concessões aos parceiros de integração foi diminuindo. Embora o Mercosul continuasse a fazer parte das prioridades da política externa brasileira, o Brasil passou a se mostrar mais relutante em ceder às pressões argentinas em nome da continuidade do processo de integração.

3.4 - CRise do Bloco (1999-2004)

A partir de 1999 o fluxo de comércio intra-regional sofreu uma reversão e tornou-se menos dinâmico. A falta de acordo entre os membros sobre diversos pontos e o descumprimento de compromissos assumidos fez com que os assuntos pendentes se multiplicassem. As divergências entre o Brasil e a Argentina se tornaram mais politizadas.

A desvalorização da moeda brasileira, em janeiro de 1999, com a subseqüente adoção de um regime de flutuação cambial, sem prévia consulta aos demais membros do bloco, é apontada como o acontecimento que marca o início da crise do bloco. A disparidade cambial combinou-se com a queda da atividade econômica e do comércio intra-bloco, sem que as instituições e normas do bloco tenham conseguido fornecer respostas eficazes. Setores argentinos passaram a temer a queda de suas exportações para o Brasil e uma invasão de 
produtos brasileiros em seu mercado, e o governo da Argentina respondeu com a adoção de medidas protecionistas unilaterais contra produtos brasileiros, como têxteis, avícolas, siderúrgicos, calçados, papel, entre outros, além de reforçar barreiras fito-sanitárias.

A medida cambial unilateral brasileira, bem como as medidas comerciais unilaterais adotadas pela Argentina serviram para demonstrar não apenas as "insuficiências do Mercosul" no plano institucional, com a existência de "vazios normativos, imprecisões das regras do jogo e falta de precisão para fazer frente às emergências críticas" (PEÑA, 2000, p. 4). Serviram também para demonstrar que, face a emergências, os dois atores mais relevantes do processo não deixaram de aplicar as medidas mais convenientes aos seus interesses nacionais, ainda que essas medidas ferissem o desempenho do Mercosul e os compromissos assumidos no âmbito do bloco.

A diminuição do comércio intra-Mercosul registrada em 1999 marcou um acontecimento sem precedentes na história do bloco. As exportações intra-bloco experimentaram um declínio crescente a partir de então, registrando a marca de $17,11 \%$ das exportações totais do bloco em 2001 e 11,94\% das exportações totais do bloco em 2003, porcentagem semelhante àquela do início de funcionamento do Mercosul. A interdependência reduziu-se e os fluxos de comércio não mais voltaram a superar os índices registrados no período anterior à crise. A Argentina, que em 1998 destinava 35,64\% de suas exportações para o Mercosul, em 2004 destinou apenas 19,59\% de suas exportações para os demais países do bloco (Tabela 3). O Brasil destinava 17,37\% de suas exportações para o Mercosul em 1998; em 2004 este percentual foi de 9,24\% (Tabela 4).

A politização dos conflitos no interior do bloco haviam adquirido um enorme vulto, e foi nesse contexto que os ministros das relações exteriores, da fazenda e da defesa do Brasil e da Argentina reuniram-se, em Buenos Aires, em abril de 2000, para uma reunião em que foi discutida a proposta de "Relançamento do Mercosul". Foram acordadas, então, as seguintes medidas: a realização de consultas e coordenação de posicionamento em questões de política externa; a coordenação de políticas macroeconômicas, com a possibilidade de extensão da coordenação não apenas para o Uruguai e Paraguai, mas também para Chile e Bolívia; a concretização de avanços na integração dos mercados de capital; o aprofundamento da integração no setor energético; o aperfeiçoamento, junto com o Paraguai e o Uruguai dos 
mecanismos de solução de controvérsias do Mercosul, iniciativa que possibilitou a assinatura do Protocolo de Olivos, que criou um Tribunal Permanente para o bloco. O Tribunal Permanente de Revisão, criado a partir do Protocolo de Olivos, constitui a única inovação institucional significativa do bloco desde a estrutura definitiva adotada em 1994.

Com exceção da criação do Tribunal Permanente de Revisão em 2006, tais esforços não surtiram efeito prático, e novos acontecimentos se somaram para impedir a consecução de grande parte das metas estabelecidas. A partir de 2001 a Argentina mergulhou numa crise econômica e política de grandes proporções, o que motivou o governo desse país a buscar saída em novas medidas protecionistas unilaterais com a finalidade de restabelecer sua economia.

O Ministro da Economia da Argentina, Domingo Cavallo, prometendo revitalizar a economia de seu país, suspendeu unilateralmente a Tarifa Externa Comum para determinados produtos ao adotar tarifas diferentes das acordadas. Cavallo fez ainda declarações em que deixava explícita a intenção de fazer o Mercosul retroceder a uma Zona de Livre Comércio. O ministro alegava que o Mercosul, tal como estava constituído, não trazia benefícios para a Argentina, e culpava o Brasil pelo insucesso do bloco. Tal posicionamento do Ministro argentino contribuiu para agravar ainda mais a situação de crise que se instalara desde a desvalorização do real em janeiro de 1999.

Com um esquema de normas pouco eficazes para conter as transgressões aos acordos e o estágio de união aduaneira colocado em cheque, os contenciosos entre os países do bloco passaram a ser cada vez mais freqüentes, e inúmeras vezes os mais altos escalões do governo, principalmente do Brasil e da Argentina, tiveram que intervir para prevenir uma deterioração ainda maior do bloco.

A ineficácia normativa é percebida no fato de que apenas cerca da metade das decisões produzidas no âmbito do Mercosul são internalizadas pelos Estados membros (BADÁN, 2002) e na irrelevância de determinadas decisões. De acordo com BOUZAS, 
inflação normativa só acrescentou o acervo de decisões sem efeito prático (2002, pp. 52-53).

A opção por uma estrutura intergovernamental e sem aplicação imediata das normas abre a possibilidade para um enorme hiato entre as normas produzidas e as normas em vigor. Os termos do Protocolo de Ouro Preto determinam a obrigatoriedade das normas, mas elas não são internalizadas de forma automática, pois o modelo de características européias com aplicabilidade direta e primazia sobre as normas nacionais - foi descartado durante as negociações para a assinatura do Protocolo de Ouro Preto. A internalização das normas está sujeita aos mecanismos internos de cada país e na disposição destes em incorporá-las, de forma que "basta que um dos Estados considere desnecessária a incorporação para que seja colocado em risco até o estabelecimento do mercado comum" (ARAÚJO, 2000, p. 108).

É preciso salientar que as opções institucionais são produto das escolhas e deliberações dos países que compõem o arranjo. Muitas vezes aponta-se a fragilidade institucional do Mercosul como um problema a ser enfrentado pelos parceiros da integração como se as instituições fossem um produto externo, alheio à vontade destes países. Ora, a estrutura institucional faz parte do processo de integração, e reflete a preferência dos membros. Ocorre que quanto mais autonomia se confere às instituições, no sentido da supranacionalização, menor é a autonomia dos Estados envolvidos. É justamente essa a razão da resistência a um aprofundamento institucional, não apenas no caso do Mercosul, mas em qualquer arranjo entre Estados.

Embora o Mercosul tenha demonstrado um vigor comercial promissor em seus primeiros anos de funcionamento, os dois maiores parceiros do bloco - a Argentina e principalmente o Brasil - resistiram em dota-lo de uma maior autonomia institucional. $\mathrm{O}$ forte incremento comercial intra-regional que vai de 1991 a 1998, aumentando ao longo deste período a interdependência entre os sócios, não foi suficiente para assegurar o comprometimento de ambos os países com bloco de maneira que os benefícios da integração se colocassem acima de interesses particulares. Embora o Mercosul seja referido como item central em grande parte dos discursos dos atores de política externa tanto do Brasil quanto da Argentina, atitudes que contrariam os acordos regionais e medidas unilaterais que vão de encontro à agenda do bloco sempre existiram, e se tornaram ainda mais contundentes a partir de 1999. 


\section{5 - Sumário da Dinâmica Comercial do Mercosul}

Espera-se que um bloco comercial regional produza o aumento dos fluxos de comércio intra-bloco, ocasionando, assim, uma intensificação da interdependência entre os Estados que o integram. No caso do Mercosul, os Estados-membros apresentam um padrão histórico de comércio entre si relativamente pouco dinâmico.

No ano em que o Mercosul entrou em vigor, apenas 11\% das exportações do bloco foram destinadas aos próprios sócios regionais. Este percentual é baixo comparado ao de outros blocos regionais, como o NAFTA, que registrou 52\% de exportações intra-regionais no ano de 1994, quando entrou em vigor, e a ASEAN (Association of South East Asian Nations, ou Associação das Nações do Sudeste Asiático), cujas exportações intra-regionais alcançaram 36\% em $1992^{13}$, ano em que a Associação se tornou uma Zona de Livre Comércio ${ }^{14}$.

Tradicionalmente, as economias da América Latina são exportadoras de produtos primários e importadoras de bens manufaturados. Este perfil não é adequado para descrever todas as economias da região, como no caso do Brasil e do México, países que obtiveram sucesso em suas políticas de industrialização. Contudo, dado este perfil de comércio internacional que vigorou para a maioria dos Estados latino-americanos por um longo período, estes países apresentam um relativamente fraco comércio entre si, em função da falta de complementaridade entre as suas economias. Os principais destinos das exportações latino-americanas são tradicionalmente os grandes mercados consumidores representados pelos Estados Unidos e pelas economias da Europa. Nos últimos anos alguns países latino-americanos vêm conseguindo diversificar seus destinos de exportação, alterando este perfil.

\footnotetext{
${ }^{13}$ Dados da UNCTAD. Disponível na web: www.unctad.org. Resgatado em 2005.

${ }^{14}$ A Asean foi constituída em 1967, com o objetivo inicial de promover ações concertadas para desenvolver a região e aumentar sua estabilidade. Somente em 1992 os Estados membros - Brunei, Camboja, Cingapura, Filipinas, Indonésia, Laos, Myanmar, Tailândia e Vietnã, tendo ainda a Papua Nova-Guiné como membro observador - decidiram transformar a Associação em uma zona de livre comércio a ser completamente implantada até 2008.
} 
No caso dos países que compõem o Mercosul as exportações para a América Latina aumentaram nas últimas décadas. Conforme é possível observar na Tabela 2, em 1970 a América Latina era o destino de $25,16 \%$ das exportações dos países que hoje integram o Mercosul. Em 1990 este percentual subiu para 31,05\%, e em 2002 para 37,30\%. A América Latina tem sido o destino de cerca de 1/3 das exportações totais do bloco nas últimas décadas e vem ampliando sua participação gradativamente.

\section{Tabela 2: Exportações do Mercosul por região (\%)}

\begin{tabular}{|l|c|c|c|c|c|c|c|c|c|c|c|c|c|c|c|}
\hline \multicolumn{1}{|c|}{ ANO } & $\mathbf{1 9 7 0}$ & $\mathbf{1 9 7 5}$ & $\mathbf{1 9 8 0}$ & $\mathbf{1 9 8 5}$ & $\mathbf{1 9 9 0}$ & $\mathbf{1 9 9 5}$ & $\mathbf{1 9 9 6}$ & $\mathbf{1 9 9 7}$ & $\mathbf{1 9 9 8}$ & $\mathbf{1 9 9 9}$ & $\mathbf{2 0 0 0}$ & $\mathbf{2 0 0 1}$ & $\mathbf{2 0 0 2}$ & $\mathbf{2 0 0 3}$ & $\mathbf{2 0 0 4}$ \\
\hline Intra-Mercosul & 9,39 & 8,50 & 11,60 & 5,54 & 8,86 & 20,28 & 22,64 & 24,79 & 24,98 & 20,57 & 20,00 & 17,11 & 11,47 & 11,94 & 12,04 \\
\hline A. Latina & 25,16 & 25,81 & 24,89 & 32,20 & 31,05 & 26,82 & 26,74 & 25,72 & 27,02 & 30,42 & 31,71 & 34,46 & 37,30 & 34,51 & 33,33 \\
\hline Outras regiões & 74,84 & 74,19 & 75,11 & 67,80 & 68,95 & 73,18 & 76,26 & 74,28 & 75,02 & 72,98 & 68,29 & 65,54 & 62,70 & 65,49 & 66,67 \\
\hline
\end{tabular}

Fonte: UNCTAD. Disponível na internet: www.unctad.org. Resgatado em 2005.

A criação do Mercosul, contudo, teve o efeito de concentrar as exportações dos quatro países que compõem o bloco na esfera intra-bloco, ocasionando um encapsulamento do comércio. Observe-se que o aumento das exportações intra-Mercosul ocorrem num ritmo mais dinâmico a partir da década de 90, sendo bastante superior ao aumento das exportações para a América Latina como um todo no mesmo período. Desta forma, em 1970 as exportações dos membros do bloco para a América Latina como um todo representavam 25,16\%; se o Mercosul já existisse, as exportações intra-bloco representariam 9,39\% das exportações totais. Em 1995, quatro anos após a criação do Mercosul, as exportações totais para a América Latina atingiram a marca de 26,82\%,e as exportações intra-Mercosul 20,28\%. Em 1998, a América Latina como um todo foi destino de 27,02\% das exportações dos países do Mercosul, e as exportações intra-bloco chegaram a 24,98\%. O crescimento das exportações para a América Latina durante todo o período foi pouco expressivo. Contudo, praticamente todo o volume de exportações para os países latino-americanos ficou concentrado no interior do bloco.

A criação do Mercosul, portanto, surtiu o efeito de encapsulamento do comércio, isto é, parte do comércio antes realizado com países de fora do acordo passou a ocorrer entre os membros do bloco. Esse desvio de comércio no caso dos demais países da América Latina foi tão dramático que no período de maior vigor comercial do Mercosul 
(1995-1998) praticamente todo o comércio praticado entre economias do Mercosul com os demais países latino-americanos se concentrou no interior do próprio bloco.

Ao analisarmos o padrão de exportações por país integrante do Mercosul podemos verificar que a criação do bloco surtiu efeitos sobre as economias de todos eles. Em muitos casos o padrão de exportações segundo o destino se alterou de maneira dramática da década de 70 para cá. A criação do Mercosul na década de 90 surte um impacto importante no perfil de exportações dos países membros.

Tabela 3: Exportações argentinas segundo o destino (\%)

\begin{tabular}{|l|r|r|r|r|r|r|r|r|r|r|r|}
\hline Destino & $\mathbf{1 9 7 0}$ & $\mathbf{1 9 7 5}$ & $\mathbf{1 9 8 0}$ & $\mathbf{1 9 8 5}$ & $\mathbf{1 9 9 0}$ & $\mathbf{1 9 9 1}$ & $\mathbf{1 9 9 2}$ & $\mathbf{1 9 9 4}$ & $\mathbf{1 9 9 8}$ & $\mathbf{2 0 0 2}$ & $\mathbf{2 0 0 4}$ \\
\hline Países do Mercosul & 10.25 & 9.85 & 14.17 & 7.95 & 14.84 & 16.51 & 19.02 & 30.33 & 35.64 & 22.31 & 19.59 \\
\hline Demais membros da ALADI & 6.06 & 10.44 & 4.22 & 4.37 & 6.34 & 6.04 & 6.66 & 8.03 & 8.01 & 14.14 & 14.10 \\
\hline União Européia & 53.67 & 35.78 & 31.04 & 24.62 & 30.85 & 33.57 & 31.05 & 24.82 & 17.50 & 19.94 & 17.17 \\
\hline Estados Unidos & 8.77 & 6.41 & 8.68 & 11.95 & 13.48 & 10.11 & 10.83 & 10.88 & 8.29 & 11.27 & 10.80 \\
\hline Outros Países & 21.25 & 37.52 & 41.89 & 51.11 & 34.49 & 33.78 & 32.44 & 25.94 & 30.55 & 32.33 & 38.32 \\
\hline Total & 100 & 100 & 100 & 100 & 100 & 100 & 100 & 100 & 100 & 100 & 100 \\
\hline
\end{tabular}

As exportações argentinas para a América Latina vêm crescendo nas últimas décadas, e alguns mercados consumidores de produtos argentinos perderam sua importância para o país. Em 1970, 53,67\% das exportações argentinas foram destinadas a países da União Européia. Em 2004, apenas 17,17\% das exportações tiveram este destino. A porcentagem de exportações argentinas para os Estados Unidos se mantém relativamente estável desde a década de 70, em torno de 10\%. Além da América Latina, outros mercados que não aqueles representados pelos países da União Européia e os Estados Unidos adquiriram importância como destino das exportações argentinas, ou seja, a Argentina diversificou os destinos de suas exportações.

Os países do Mercosul foram os responsáveis pela absorção de 10,25\% das exportações argentinas em 1970. Até a criação do Mercosul, houve pouca variação nesta porcentagem. Quando o Mercosul entrou em vigor, em 1991, os demais países do bloco absorveram 16,51\% das exportações argentinas. De 1991 até 1994, quando se conclui o período de transição, a Argentina havia praticamente dobrado suas exportações para os membros do bloco, que passou para $30,33 \%$ das exportações totais argentinas. Este índice 
continuou aumentando até 1998. Neste ano, 35,64\% das exportações argentinas foram destinadas ao Mercosul. Mas a partir de 1999, conforme vimos acima, a dinâmica comercial do Mercosul sofre uma inflexão e as exportações argentinas intra-bloco decaem, sendo que em 2004 a porcentagem das exportações argentinas para o Mercosul era praticamente a mesma de $1991(19,59 \%)$.

As exportações argentinas para os demais países que compõem a ALADI também aumentaram no período analisado. Contudo, neste caso o crescimento foi contínuo e menos significativo, passando de 6,06\% em 1970 para 14,10\% em 2004.

A importância do Mercosul e da América Latina como um todo como destino de exportações também vêm aumentando no caso brasileiro. Contudo, outras regiões ainda são o destino preferencial das exportações brasileiras. Em 1970, apenas 1,59\% das exportações brasileiras tinham como destino os países membros da ALADI, excetuando-se os países que hoje integram o Mercosul. Neste mesmo ano os países da União Européia receberam 43,73\% das exportações brasileiras, mas este índice vem caindo, e em 2004 apenas $24,25 \%$ das exportações brasileiras foram direcionadas ao bloco europeu. As exportações para os Estados Unidos sofreram algumas oscilações neste período, mas em média correspondem a cerca de $20 \%$ das exportações totais. As exportações para os membros da ALADI cresceram, passando para 3,15\% em 1990 e 6,73\% em 2004. As outras regiões do mundo foram as que mais cresceram em importância como destino das exportações brasileiras: em 2004, 39,01\% das exportações foram destinadas a outras regiões que não as mencionadas acima.

\section{Tabela 4: Exportações brasileiras segundo o destino (\%)}

\begin{tabular}{|l|r|r|r|r|r|r|r|r|r|r|r|}
\hline Destino & $\mathbf{1 9 7 0}$ & $\mathbf{1 9 7 5}$ & $\mathbf{1 9 8 0}$ & $\mathbf{1 9 8 5}$ & $\mathbf{1 9 9 0}$ & $\mathbf{1 9 9 1}$ & $\mathbf{1 9 9 2}$ & $\mathbf{1 9 9 4}$ & $\mathbf{1 9 9 8}$ & $\mathbf{2 0 0 2}$ & $\mathbf{2 0 0 4}$ \\
\hline Países do Mercosul & 8.21 & 6.54 & 9.02 & 3.86 & 4.20 & 7.30 & 11.39 & 13.59 & 17.37 & 5.48 & 9.24 \\
\hline Demais membros da ALADI & 1.59 & 2.63 & 4.58 & 1.79 & 3.15 & 4.54 & 5.66 & 4.70 & 3.96 & 6.30 & 6.73 \\
\hline União Européia & 43.73 & 34.68 & 32.25 & 28.42 & 32.36 & 32.11 & 30.21 & 28.01 & 28.84 & 25.01 & 24.25 \\
\hline Estados Unidos & 24.77 & 15.06 & 17.03 & 26.70 & 24.17 & 19.81 & 19.27 & 20.24 & 19.06 & 25.44 & 20.77 \\
\hline Outros Países & 21.70 & 41.09 & 37.13 & 39.23 & 36.12 & 36.24 & 33.47 & 33.45 & 30.78 & 37.77 & 39.01 \\
\hline Total & 100 & 100 & 100 & 100 & 100 & 100 & 100 & 100 & 100 & 100 & 100 \\
\hline
\end{tabular}

O Brasil é o membro que possui o menor percentual de exportações intrabloco. Contudo, de 1991 a 1998 as exportações destinadas aos demais membros do Mercosul 
mais que dobraram, passando de 7,30\% a 17,37\%. Também no caso brasileiro, a partir de 1999 há uma reversão nas exportações destinadas ao bloco, que passam a decair. Novamente, ao final de 2004 o percentual de exportações brasileiras destinadas ao Mercosul se assemelha ao percentual do primeiro ano de funcionamento do bloco $(9,24 \%)$.

O Paraguai, por sua vez, viu as exportações destinadas ao Mercosul crescerem de maneira significativa, sem que elas experimentassem uma reversão tão forte quanto os demais países do bloco a partir de 1999. Este país sofreu uma grande variação em seus destinos de exportação desde os anos 70. Ao longo das décadas de 70 e 80 o principal destino das exportações paraguaias era a União Européia, que absorveu 37,64\% das exportações paraguaias em 1970 e 50,11\% em 1985. A partir deste período, contudo, as exportações para a União Européia caem dramaticamente: em 1990 31,75\% das exportações paraguaias foram destinadas ao bloco europeu, e em 2004 este índice cai para apenas 6,18\%. Os Estados Unidos nunca foram um destino primordial para as exportações paraguaias, mas também tiveram sua importância reduzida: em 1970 13,89\% das exportações paraguaias eram destinadas aos Estados Unidos, e em 2004 apenas 3,20\% foram absorvidas por este país.

Tabela 5: Exportações paraguaias segundo o destino (\%)

\begin{tabular}{|l|r|r|r|r|r|r|r|r|r|r|r|}
\hline Destino & $\mathbf{1 9 7 0}$ & $\mathbf{1 9 7 5}$ & $\mathbf{1 9 8 0}$ & $\mathbf{1 9 8 5}$ & $\mathbf{1 9 9 0}$ & $\mathbf{1 9 9 1}$ & $\mathbf{1 9 9 2}$ & $\mathbf{1 9 9 4}$ & $\mathbf{1 9 9 8}$ & $\mathbf{2 0 0 2}$ & $\mathbf{2 0 0 4}$ \\
\hline Países do Mercosul & 33.50 & 33.09 & 40.16 & 27.05 & 39.57 & 35.19 & 37.53 & 52.01 & 52.34 & 58.15 & 53.24 \\
\hline Demais membros da ALADI & 3.45 & 1.83 & 4.94 & 4.39 & 3.27 & 6.60 & 7.46 & 4.49 & 4.08 & 5.31 & 2.10 \\
\hline União Européia & 37.64 & 42.28 & 30.91 & 50.11 & 31.75 & 32.01 & 34.29 & 27.76 & 28.12 & 8.71 & 6.18 \\
\hline Estados Unidos & 13.89 & 7.80 & 5.38 & 1.19 & 4.11 & 4.64 & 5.24 & 6.97 & 8.06 & 3.93 & 3.20 \\
\hline Outros Países & 11.53 & 15.00 & 18.62 & 17.27 & 21.30 & 21.55 & 15.48 & 8.77 & 7.41 & 23.91 & 35.27 \\
\hline Total & 100 & 100 & 100 & 100 & 100 & 100 & 100 & 100 & 100 & 100 & 100 \\
\hline
\end{tabular}

Fonte: CEPAL. Disponível na internet: www.cepal.org. Resgatado em 2005.

Os demais membros do Mercosul sempre tiveram importância como destino das exportações paraguaias. Já em 1970 a Argentina, o Brasil e o Uruguai juntos recebiam 33,50\% das exportações provenientes do Paraguai. Em 1991, quando o Mercosul entrou em vigor, 35,19\% das exportações paraguaias foram destinadas ao bloco. As exportações paraguaias para os demais membros do Mercosul continuaram aumentando até 2002, ano em que representaram $58,15 \%$ das exportações totais. A partir de então, também as exportações paraguaias destinadas ao bloco sofrem uma reversão, porém menos dramática. Em 2004, o Paraguai ainda destinava mais da metade de suas exportações ao bloco $(53,24 \%)$. Já os 
demais países da ALADI recebem uma porcentagem pequena das exportações paraguaias. Os países de outras regiões do mundo também vêm ganhando importância como destino das exportações paraguaias nos últimos anos.

Assim como o Paraguai, o Uruguai também experimentou uma mudança notável no destino de suas exportações desde a década de 70. Os Estados Unidos aumentaram sua importância como destino das exportações uruguaias. Em 1970, 8,51\% das exportações uruguaias tinham como destino os Estados Unidos. Este índice não sofreu variações dramáticas até 2002, mas em 2004 19,76\% das exportações uruguaias foram absorvidas por este país. Já a União Européia era destino de 55,71\% das exportações uruguaias. Ao longo dos anos este percentual foi diminuindo, e em 2004 apenas 19,47\% das exportações uruguaias tiveram o bloco europeu como destino. No mesmo período, as exportações direcionadas aos membros da ALADI, com exceção dos países do Mercosul, cresceram de maneira gradual, passando de 1,32\% em 1970 para 6,09\% em 2004.

\section{Tabela 6: Exportações uruguaias segundo o destino (\%)}

\begin{tabular}{|l|r|r|r|r|r|r|r|r|r|r|r|}
\hline Destino & $\mathbf{1 9 7 0}$ & $\mathbf{1 9 7 5}$ & $\mathbf{1 9 8 0}$ & $\mathbf{1 9 8 5}$ & $\mathbf{1 9 9 0}$ & $\mathbf{1 9 9 1}$ & $\mathbf{1 9 9 2}$ & $\mathbf{1 9 9 4}$ & $\mathbf{1 9 9 8}$ & $\mathbf{2 0 0 2}$ & $\mathbf{2 0 0 4}$ \\
\hline Países do Mercosul & 8.75 & 25.25 & 32.85 & 24.93 & 34.83 & 35.42 & 33.60 & 47.01 & 55.33 & 32.61 & 26.18 \\
\hline Demais membros da ALADI & 1.32 & 1.16 & 2.68 & 1.26 & 2.91 & 3.21 & 5.67 & 4.59 & 3.58 & 6.68 & 6.09 \\
\hline União Européia & 55.71 & 42.14 & 31.98 & 22.69 & 25.07 & 25.42 & 26.75 & 20.79 & 16.48 & 23.71 & 19.47 \\
\hline Estados Unidos & 8.51 & 6.79 & 7.71 & 14.73 & 9.27 & 9.94 & 10.56 & 6.82 & 5.72 & 7.41 & 19.76 \\
\hline Outros Países & 25.71 & 24.65 & 24.77 & 36.38 & 27.93 & 26.00 & 23.43 & 20.79 & 18.88 & 29.59 & 28.50 \\
\hline Total & 100 & 100 & 100 & 100 & 100 & 100 & 100 & 100 & 100 & 100 & 100 \\
\hline
\end{tabular}

As exportações destinadas ao Mercosul sofreram grandes variações ao longo do período. Em 1970, apenas 8,75\% das exportações uruguaias foram destinadas ao Brasil, à Argentina e ao Paraguai. Em 1975 este percentual já havia aumentado para 25,25\%. De 1991 a 1998 as exportações uruguaias para o Mercosul aumentaram de maneira expressiva, período em que passaram de um percentual de 35,42\% para 55,33\%. Novamente, observa-se uma reversão das exportações destinadas ao bloco a partir de 1999, no caso do Uruguai de modo ainda mais dramático: em 2004, apenas 26,18\% das exportações uruguaias foram destinadas aos demais membros do Mercosul, um percentual menor do que aquele registrado no primeiro ano de funcionamento do bloco, e similar ao patamar registrado em 1975. As outras regiões 
do mundo também possuem importância como destino das exportações uruguaias, correspondendo em média a $25 \%$ das exportações ao longo do período analisado.

Podemos observar que a criação do Mercosul surtiu efeitos significativos sobre o padrão de exportações dos países membros. $\mathrm{O}$ impacto do bloco não se fez sentir de maneira uniforme sobre todos os países, mas de modo geral todos eles experimentaram um aumento significativo das suas exportações intra-Mercosul ao menos até 1998. A partir de 1999, quando as tensões entre os membros começam a se agravar, percebe-se uma mudança no padrão de exportações intra-regionais, de forma mais ou menos dramática conforme o país em questão.

Mesmo com uma reversão a partir de 1999, é possível notar a importância que o bloco adquiriu para os países membros e o aumento da interdependência entre eles. Em 2004, o Brasil teve nos demais membros do bloco o destino de pouco menos que $10 \%$ de suas exportações totais. É o país que menos exporta para o bloco em termos percentuais. Já as exportações argentinas para o Mercosul chegaram a quase $20 \%$ das exportações totais em 2004. Em 1998, no auge comercial do Mercosul, esse percentual havia chegado a 35\%, isto é, mais de 1/3 das exportações argentinas tiveram como destino os outros membros do bloco. Em 2004 o Uruguai exportou para o Mercosul pouco mais de 1/4 das exportações totais do país, mas o Uruguai já chegou a destinar mais de metade das suas exportações para o Mercosul. O Paraguai ainda tem no Mercosul seu principal destino de exportação: mais de metade de suas exportações são destinadas ao bloco. A interdependência entre os membros se aprofundou de maneira notável de 1991 a 1998, e, embora o comércio intra-regional tenha decaído a partir de 1999, o bloco ainda possui uma importância comercial significativa para seus membros.

Uma vez que às exportações corresponde um percentual do PIB, podemos observar um impacto da dinâmica comercial do Mercosul também sobre o PIB dos Estados membros. Para tanto, avalia-se a que porcentagem do PIB correspondem as exportações destinadas aos demais membros do bloco. Conforme os dados expostos na Tabela 7, 1,04\% do PIB argentino em 1991 era proveniente das exportações destinadas ao Mercosul. Este percentual aumenta até 2002 (5,61\%), decaindo em 2004 (4,3\%). Conforme observado acima, a partir de 1999, diminuíram as exportações argentinas destinadas ao Mercosul. Apesar disso, 
o Mercosul continuou tendo importância crescente para a Argentina no que diz respeito à composição de seu PIB até 2002, e mesmo decaindo em 2004, registra ainda uma importância bastante superior àquela que 1991. Isto é, há um aumento da importância do Mercosul na composição do PIB argentino, apesar da diminuição das exportações deste país para os demais membros do bloco a partir de $1999^{15}$.

A contribuição das exportações intra-Mercosul no PIB brasileiro apresenta uma correspondência em relação ao percentual das exportações brasileiras destinadas ao bloco até 1998. Isto é, no mesmo período em que aumenta o percentual das exportações destinadas ao bloco, aumenta também a importância do Mercosul na composição do PIB brasileiro, que passa de 0,57\% em 1991 para 1,13\% em 1998. Após esse período, a participação das exportações para o Mercosul em seu PIB tem oscilado. O Paraguai é o país cujo percentual de exportações intra-Mercosul é o maior dentre os quatro membros, e também aquele para o qual o Mercosul possui a maior importância na composição do PIB. A participação das exportações intra-bloco na composição do PIB paraguaio aumenta de 1991 a 1998, quando passa de 7\% para 17,07\%, e, embora apresente um decréscimo em 2000 (14,65\%), volta a subir nos anos subseqüentes, chegando a contribuir com 22,54\% do PIB em 2004. O Mercosul também tem uma importância significativa para o Uruguai. Desde a criação do bloco, os recursos obtidos com as exportações para os demais membros tem correspondido a cerca de $5 \%$ do PIB uruguaio.

Tabela 7: Participação das exportações intra-Mercosul no PIB dos Estados membros (\%)

\begin{tabular}{|c|c|c|c|c|c|c|}
\hline \multicolumn{7}{|c|}{$\begin{array}{c}\text { Participação das exportações intra-Mercosul } \\
\text { no PIB dos Estados membros }(\%)\end{array}$} \\
\hline & 1991 & 1994 & 1998 & 2000 & 2002 & 2004 \\
\hline Argentina & 1,04 & 1,86 & 2,87 & 2,96 & 5,61 & 4,3 \\
\hline Brasil & 0,57 & 1,08 & 1,13 & 1,29 & 0,72 & 1,5 \\
\hline Paraguai & 7 & 12,47 & 17,07 & 14,65 & 16,4 & 22,54 \\
\hline Uruguai & 5,45 & 2,96 & 6,85 & 5,1 & 4,94 & 4,1 \\
\hline
\end{tabular}

\footnotetext{
${ }^{15} \mathrm{O}$ aumento da importância do Mercosul na composição do PIB argentino apesar da diminuição das exportações talvez seja explicada pela grave crise econômica experimentada por este país a partir de 2001 e de lenta recuperação. Esta averiguação, contudo, não corresponde aos propósitos deste trabalho.
} 
Observe-se que, embora o comércio entre os membros do Mercosul fosse relativamente fraco no momento de constituição do bloco, a criação da Zona de Livre Comércio e posteriormente da União Aduaneira conseguiu alavancar o comércio intraregional, aumentando o percentual de trocas efetuadas no interior do bloco e produzindo o efeito de intensificação da interdependência entre os quatro Estados membros.

O fluxo de comércio intra-regional aumentou continuamente do momento da criação do bloco, em 1991, até 1998, intensificando, portanto, a interdependência entre os sócios. Contudo, este aumento da do comércio intra-regional e da interdependência não encontrou correspondência na disponibilidade brasileira em arcar com determinados custos para dar continuidade ao processo de integração. Dessa forma, o início promissor do bloco não resultou em um aprofundamento cada vez maior da integração ou na ampliação da agenda e da cooperação entre os parceiros da integração. Em outras palavras, não foi observado o efeito de spill-over. Em vez da ampliação da agenda, o que se observou no Mercosul foi cada vez o acúmulo de agenda não concluída e a deterioração de compromissos que já estavam estabelecidos.

Apenas no início do processo de integração o Brasil - a maior economia do bloco - esteve disposto a ceder às reivindicações dos parceiros de integração em nome da continuidade do processo, o que aconteceu, conforme exposto no Capítulo 2, em função dos interesses estratégicos que o Brasil possui no Mercosul. Apesar da interdependência entre os membros do bloco ter se intensificado continuamente nos anos subseqüentes, o Brasil passou a se mostrar menos sensível às reivindicações dos demais membros do Mercosul ao longo da década de 90. Em 1999 ocorre uma reversão no padrão do comércio intra-regional, que a partir de então não mais retornou aos índices conquistados até 1998. Paralelamente, os conflitos entre os membros se politizaram e a sensação se crise passou a ser crescente.

Embora o Mercosul continue figurando como tema prioritário da política externa dos países que compõem e até tenha sido proposta uma agenda de relançamento do bloco, nenhum resultado prático foi alcançado no sentido de que o Mercosul voltasse a produzir os efeitos positivos que foram registrados durante o período de transição, e, em menor medida, após a implantação da União Aduaneira até 1998. 


\section{Conclusão}

As teorias das relações internacionais consideradas neste trabalho possuem como ponto comum a suposição de que os Estados que compõem o sistema internacional são unidades racionais dotadas de interesses e de percepções acerca do sistema no qual estão inseridas. Em relação ao estabelecimento de arranjos de integração regional e outros arranjos cooperativos (instituições e regimes), estas teorias divergem quanto às possibilidades de estabelecimento de verdadeiros arranjos cooperativos, quanto às potencialidades e os limites desses arranjos e quanto a sua capacidade de condicionar mudanças no comportamento dos Estados.

De acordo com o neo-realismo, os Estados são sempre motivados por considerações de poder, e, dado que o sistema internacional é anárquico, estão constantemente preocupados com as capacidades relativas de poder. Em função disso, a adesão dos Estados aos arranjos de integração e sua permanência neles está condicionada pela percepção de ganhos tanto absolutos quanto relativos e por interesses estratégicos. Tal como na política de formação de alianças, os arranjos cooperativos tendem a ser instáveis. Os Estados somente têm incentivos para permanecer em arranjos cooperativos com a finalidade de obter algum ganho e no caso desta finalidade ser de fato correspondida. Não há nenhuma outra motivação para que os Estados integrem arranjos de cooperação.

Já o neofuncionalismo e o institucionalismo interpretam que existem, sim, motivações adicionais para que os Estados promovam sua adesão aos acordos de integração regional e outros arranjos cooperativos. Em ambos os casos, os Estados também aderem aos arranjos em função de seu interesse em obter ganhos absolutos que não seriam conquistados pela ação isolada de cada Estado. No caso do funcionalismo, a primeira motivação é a realização de tarefas técnicas que somente podem ser solucionadas mediante a ação conjunta. Contudo, uma vez que a cooperação tenha se originado para a solução de uma determinada tarefa, novos problemas conjuntos vão surgindo e gerando a motivação, quando não a necessidade, de mais cooperação, numa espiral crescente que caracteriza o processo de spillover. A interdependência entre os Estados vai se acentuado, reforçando ainda mais a 
cooperação. As instituições são vistas pelo neofuncionalismos como mecanismos que coordenam e reforçam a tendência cooperativa.

O institucionalismo concorda com a interpretação realista de que as características do sistema internacional, sobretudo a organização anárquica, são um impeditivo para que se estabeleçam relações cooperativas entre os Estados. Entretanto, argumenta que há ganhos que só podem ser obtidos mediante a cooperação, pois há interdependência entre os Estados e interesses mútuos. Para superar os problemas de ação coletiva que decorrem das características do sistema são criadas as instituições internacionais. As instituições desempenham papéis que minimizam os problemas de ação coletiva, possibilitando a emergência da cooperação. De acordo com o institucionalismo, os ganhos obtidos com a cooperação e os papéis desempenhados pelas instituições condicionariam os Estados em seu comportamento. Uma vez envolvidos em arranjos cooperativos, os Estados tenderiam a desenvolver relações mais pacíficas entre si e conservarem sua adesão aos arranjos, uma vez que abandonando-os os Estados sofreriam perdas significativas.

Tanto para a interpretação neofuncionalista quanto para a interpretação institucionalista, quanto maior a interdependência entre os Estados, maiores as possibilidades e os incentivos para a cooperação. Há no Mercosul, entretanto, uma disjunção entre a interdependência e a cooperação.

No momento da constituição do Mercosul os países membros registravam uma pequena porcentagem de exportações entre si, com exceção, talvez, do Paraguai, para quem os demais membros do bloco sempre foram destinos importantes de exportações. De maneira geral, contudo, o comércio entre as quatro economias era relativamente fraco, apesar da proximidade geográfica. Além disso, e sobretudo no caso do Brasil e da Argentina, os membros do bloco não mantinham relações estreitas entre si. Ao contrário, o Brasil e a Argentina estavam apenas iniciando uma aproximação depois de décadas de um relacionamento tenso.

Embora inseridos no contexto latino-americano e experimentando processos políticos e econômicos similares, os quatro Estados também possuíam percepções distintas acerca do sistema internacional e empregavam diferentes estratégias na perseguição de seus 
interesses. Mais uma vez, nos diferentes históricos da política externa no Brasil e da Argentina as diferenças ficam patentes.

Desse modo, pode-se afirmar que a interdependência entre o Brasil e a Argentina era baixa no momento em que estes países iniciaram as negociações para o estabelecimento de um acordo bilateral de aproximação comercial, ao qual aderiram, posteriormente, o Paraguai e o Uruguai.

Ambos os países experimentavam experiências comuns: ambos haviam passado por experiências de autoritarismo político e haviam sofrido processos de redemocratização; ambos haviam adotado por décadas uma estratégia econômica voltada para dentro e davam início a novas políticas de perfil neoliberal depois da "década perdida"; ambos buscavam resgatar a sua credibilidade junto à comunidade internacional. Contudo, as motivações para que o Brasil e a Argentina estabelecessem um acordo de integração regional eram distintas.

A Argentina esteve motivada principalmente pelos retornos comerciais que a integração com o Brasil proporcionaria. O amplo mercado consumidor brasileiro era um atrativo relevante para um país que buscava o desenvolvimento e a estabilização econômica. De um ponto de vista estratégico, o estabelecimento de relações pacíficas e cooperativas com o Brasil correspondia ao interesse argentino de abandonar a política de confrontação com seus rivais históricos (Chile e Inglaterra, e, em menor medida também o Brasil), a partir do reconhecimento de sua posição periférica no sistema internacional, e de resgatar as relações amistosas com as grandes potências, em especial os Estados Unidos.

No caso brasileiro as motivações eram inversas. Do ponto de vista comercial os parceiros do Mercosul não são destinos dos mais importantes para as exportações brasileiras. O Brasil é o país menos dependente dos demais membros do Mercosul, no que tange às suas relações comerciais. Entretanto, o Brasil possuía motivações estratégicas. Ao longo da década de 90 foi se consolidando uma estratégia da diplomacia brasileira de construir, junto à comunidade internacional, uma imagem para o Brasil de líder regional e de global player. A diplomacia brasileira busca alçar o Brasil à condição de potência média reconhecida internacionalmente, inclusive com capacidade para ocupar um assento permanente no Conselho de Segurança da ONU. 
O Brasil já se caracteriza como um global trader, uma vez que possui destinos de exportações bastante diversificados. O empenho brasileiro desde a década de 90 tem sido o de alcançar também a posição de global player, mediante o estabelecimento de relações mais próximas com países em desenvolvimento do seu entorno regional (exemplo: Mercosul; ALCSA) e de outras localidades geográficas (Comunidade dos Países de Língua Portuguesa ${ }^{16}$; Fórum de Diálogo IBAS - Índia, Brasil e África do Sul); a participação mais ativa em fóruns multilaterais (Tratado de Não-Proliferação Nuclear; Reunião do G-8 em Davos); e o exercício de um papel mais ativo em acontecimentos mundiais (envio de uma delegação brasileira ao Timor Leste de tropas ao Haiti, em ambos os casos em apoio às ações da ONU).

Dessa forma, o Mercosul corresponde aos interesses estratégicos brasileiros de consolidar uma posição de liderança regional e de potência média. Integrado a este objetivo está o interesse brasileiro de limitar a influência norte-americana na América do Sul. O Mercosul também serve a este propósito, na medida em que se trata de um processo de integração econômica alternativo à ALCA e que pretende não se restringir a uma Zona de Livre Comércio, tendo objetivos mais ambiciosos - ao menos expressos no Tratado de Assunção e resoluções posteriores - do que a simples eliminação de barreiras tarifárias.

Tais objetivos da política externa brasileira delineiam um perfil realista de atuação. É verdade que o Brasil tem conferido seu apoio a instituições e regimes internacionais, mas isso ocorre na medida em que a política externa brasileira tem o interesse maior de situar o Brasil como um ator relevante do sistema internacional, isto é, de aumentar suas capacidades relativas. A estratégia da diplomacia brasileira é tentar dissociar a imagem do Brasil de país periférico em desenvolvimento, elevando-o à condição de potência média.

Embora o Brasil não se utilize dos meios militares para tal, concentrando seus esforços em áreas de "baixa política", o objetivo é a maximização de poder, no sentido de possuir uma atuação mais ativa e efetiva no sistema internacional, como demonstra a pretensão de integrar o Conselho de Segurança da ONU de forma permanente.

\footnotetext{
${ }^{16}$ A Comunidade dos Países de Língua Portuguesa existe desde 1996 e reúne os lusófonos: Brasil, Angola, Cabo Verde, Guiné-Bissau, Moçambique, Portugal, São Tomé e Príncipe e, desde 2002, o Timor Leste. Os estatutos da Comunidade define como seus objetivos a concertação político-diplomática entre os seus membros; a cooperação econômica, social, cultural, jurídica e técnico-científica; e a promoção e difusão da língua portuguesa.
} 
A constituição do Mercosul se insere na estratégia brasileira, e de fato, o início do processo de integração foi promissor. Em seus primeiros anos de funcionamento o bloco elevou as taxas de comércio intra-regional e concretizou a agenda de liberalização comercial, alcançando sucesso na de redução das barreiras tarifárias. O crescimento do comércio intraregional aumentou a interdependência entre os quatro países membros e correspondeu ao interesse argentino de aumentar suas exportações para os países vizinhos, sobretudo para o Brasil. Até mesmo o desapontamento inicial da Argentina com o déficit na balança comercial bilateral com o Brasil foi minimizado, já que o Brasil concordou com a adoção de medidas para reverter essa situação, e logo a balança comercial se tornou favorável à Argentina. $\mathrm{O}$ Mercosul também parece ter correspondido aos interesses brasileiros, uma vez que o bloco ganhou repercussão internacional, iniciando um acordo de cooperação com a União Européia, e os quatro países lograram estabelecer com os Estados Unidos o acordo 4+1, em que firmaram posição conjunta.

Os diferentes interesses e percepções dos dois maiores membros do Mercosul não impediram que o acordo regional fosse erigido e obtivesse resultados satisfatórios em seus primeiros anos de funcionamento. O Brasil e a Argentina possuíam interesses mútuos embora distintos. Para ambos os países o relacionamento com o parceiro regional tinha importância da consecução de objetivos nacionais, fossem eles de natureza econômica ou estratégica. Os resultados comerciais apontam que o bloco teve um início bem sucedido para um bloco cujos integrantes comercializavam relativamente pouco entre si. Até 1994, com a conclusão da agenda de implementação da Zona de Livre Comércio e das bases para o funcionamento inicial da União Aduaneira, o processo de integração seguia o rumo previsto pelo Tratado de Assunção. Tudo indicava que o processo de integração continuaria sua marcha rumo ao aprofundamento comercial e à intensificação da interdependência.

De fato, até 1998 a interdependência comercial se intensificou de maneira crescente. Os fluxos do comércio intra-regional registrava taxas cada vez mais alta, e o comércio intra-bloco era cada vez mais importante na composição do PIB dos países membros. Contudo, a agenda de integração começou a dar os primeiros sinais de paralisia, com a falta de acordo em pontos importantes para a integração, impossibilitando a adoção de mecanismos de coordenação macroeconômica, a eliminação de barreiras não tarifárias, a 
adoção de mecanismos de escape institucionalmente previstos e o incremento institucional do bloco.

As diferentes percepções em relação ao bloco começaram a se manifestar, e tornava-se mais difícil conciliar os interesses. A maior interdependência ocasionada pela integração comercial não surtiu o efeito de incentivar mais cooperação entre os Estados membros. Mesmo diante da intensificação dos vínculos comerciais e da possibilidade de que o Mercosul se convertesse numa plataforma para negociações conjuntas frente a terceiros países ou blocos, o Brasil foi se tornando menos propenso a fazer concessões aos seus parceiros de integração no que tange às características institucionais do bloco em troca do apoio e do comprometimento destes com o bloco. A delegação brasileira também se mostrou terminantemente resistente à adoção de instituições supranacionais, demonstrando a preocupação com a perda da autonomia brasileira em decidir os rumos de suas políticas.

Também a Argentina manteve um comportamento hesitante, uma vez que, na busca de relações estreitas com os Estados Unidos, não pretendia que sua participação no Mercosul significasse fechar as portas para a iniciativa norte-americana de integração regional ou distanciar-se da grande potência.

Quando, em 1999, o Brasil depreciou o real e alterou sua política cambial sem prévia consulta aos demais membros do Mercosul, a politização das divergências, que estava latente, passou a ser evidente. Diante da atitude brasileira e da inflexibilidade deste país frente às suas reivindicações, a Argentina passou a ameaçar e em determinadas situações adotar de fato medidas unilaterais visando a proteção se setores mais sensíveis de sua economia, o que vai de encontro ao propósito de liberalização comercial. Os atritos e ameaças mútuas se somaram à paralisia da agenda para que uma grave crise fosse diagnosticada. Em 1999 foi registrada uma queda do comércio intra-regional, e a tendência de diminuição do comércio intra-bloco permaneceu nos anos seguintes.

Embora o Mercosul permanecesse sendo apontado como tema prioritário da política externa brasileira, ficou evidente que o Brasil tornara-se mais rígido no atendimento das reivindicações dos demais Estados-partes e que possuía outros objetivos dos quais o Brasil não estava disposto a abrir mão. 
O diagnóstico de crise levou os membros a estudarem propostas de "Relançamento do Mercosul" e a aprovarem diversas resoluções, sem que tenham conseguido, entretanto, resultados efetivos. O Mercosul ainda sofre com a agenda não concluída do bloco e com a diminuição dos fluxos de comércio intra-regionais, que nunca mais voltaram a alcançar os níveis registrados em 1998.

Tanto a corrente neo-realista quanto a institucionalista concordam que, para que haja a emergência de um regime ou instituição internacional, é necessário que haja um Estado com os meios e a disponibilidade de sustenta-lo. Este Estado deve arcar com determinados custos a fim de que a instituição possa se concretizar. A divergência entre as duas correntes, entretanto, é bastante grande. Para os realistas as instituições só são mantidas enquanto corresponderem aos interesses dos Estados envolvidos. Por isso são instáveis e sujeitas a desaparecem tão logo se alterem os interesses ou as correlações de força. Para os institucionalistas, as instituições adquirem vida própria, possuem uma dinâmica que as possibilita se descolarem dos interesses estatais para adquirirem uma certa autonomia, e até influenciarem o comportamento dos Estados.

No caso do Mercosul, o Estado com maiores capacidades para exercer uma liderança é de fato o Brasil. O Brasil se mostrou disposto a exercer essa liderança num primeiro momento, fazendo concessões aos outros membros do bloco a fim de assegurar a continuidade do processo. Mas depois de implantada a União Aduaneira, mesmo diante da intensificação comercial e do aumento da interdependência, o Brasil passou a ser mais resistente em se flexibilizar diante das reivindicações de seus parceiros a fim de assegurar que o processo de integração seguisse, conforme a vontade expressa no Tratado de Assunção, rumo a um mercado comum.

A política externa para o Mercosul se enquadra naquilo que a interpretação realista qualifica como regionalismo tático: o Mercosul é para o Brasil um dos pontos de apoio - quiçá o principal deles - na estratégia de busca de uma melhor colocação no cenário internacional, mediante o reconhecimento de que exerce uma liderança regional e de que é uma potência média com capacidade para atuar de maneira efetiva nas questões de interesse internacional. 
Paralelamente a isso, e de maneira integrada a esta estratégia, o Mercosul é para o Brasil um instrumento para fortalecer seu poder de barganha e responder a estímulos externos. Nesse segundo ponto, fica claro que o Mercosul foi utilizado pelo Brasil para aumentar sua capacidade de negociação frente à proposta de integração hemisférica.

Entretanto, diante do esfriamento das negociações da ALCA, tornou-se mais fraca uma das motivações brasileiras para investir pesadamente no Mercosul, e os custos da liderança se tornaram mais altos. Isso explica, ao menos em parte, porque o processo de integração perdeu seu dinamismo a partir de um determinado momento. Por um lado, a estratégia brasileira é de um regionalismo tático em que o Mercosul atende aos seus interesses estratégicos; por outro, a falta de disposição em arcar co os custos da liderança faz com que o Mercosul perca uma referência que não pode ser fornecida pelos demais membros do bloco, em função de uma limitação ainda maior das suas capacidades.

Não faz parte do escopo deste trabalho apontar saídas ou remédios para o diagnóstico de crise do Mercosul. A nossa intenção foi somente a de demonstrar que o Brasil vem adotando, em relação ao Mercosul, uma postura essencialmente estratégica, de acordo com os preceitos do regionalismo tático. Essa estratégia visa a consolidação de uma posição de liderança sub-regional, a fim de satisfazer as pretensões do Brasil de tornar-se um global player. A contraposição à hegemonia norte-americana na sub-região está inserida neste contexto, e constituía uma das motivações para que o Brasil tivesse a disposição de arcar com os custos da liderança sub-regional.

Delineia-se, portanto, um perfil de política externa brasileira para o Mercosul de características realistas, em que os interesses estratégicos são perseguidos, inclusive por meio da adesão a instituições. Tal postura brasileira em relação ao bloco, por outro lado, somada às distintas percepções e interesses dos demais membros, sobretudo a Argentina, tem se tornado um elemento importante a entravar o aprofundamento da cooperação no âmbito do Mercosul, uma vez que, embora utilize o Mercosul como base para suas pretensões estratégicas, o Brasil não se demonstra disposto a arcar com os custos da liderança subregional. Em suma, a postura estratégica brasileira em relação ao Mercosul tem sido um elemento importante a dificultar o fortalecimento institucional do bloco e o aprofundamento do acordo de integração rumo a um mercado comum. 


\section{REFERÊnCIAS Bibliográficas}

ALMEIDA, Paulo R. (1993). O Mercosul no Contexto Regional e Internacional. São Paulo: Aduaneiras.

ALMEIDA, Paulo R. (2002). “A Evolução do Mercosul”. Preparado para a revista Impulso [Piraciba: UNIMEP]; revisto em 17/02/2002. Disponível na internet: www.alemmar.tripod.com.br

ARAÚJO, Nádia de (2000). "Solução de Controvérsias no Mercosul”. In: CASELLA, Paulo B. (coord.). Mercosul: Integração Regional e Globalização. Rio de Janeiro: Renovar, pp. 99141.

ARNAUD, Vicente G. (1996). Mercosur, Unión Europea, NAFTA y los Procesos de Integración Regional. Buenos Aires: Abeledo-Perrot.

BADÁN, Didier O. (2002). "Reflexiones sobre el Mercosur”. In: HUGUENEY FILHO, C.; CARDIM, C. H. (org.). Grupo de Reflexão Prospectiva sobre o Mercosul. Brasília: FUNAG/IPRI/SGIE/BID, pp.13-25.

BALASSA, Bela (1961). Teoria da Integração Econômica. Lisboa: Livraria Clássica.

BERNAL-MEZA, Raúl (2002). "Política exterior Argentina: de Menem a De La Rúa - Hay Una nueva política?” in: São Paulo em Perspectiva, vol. 16, nº 1 (jan-mar), pp. 74-93.

BOUZAS, Roberto (2001). "Mercosul, dez anos depois: processo de aprendizado ou déjà$v u$ ?" In. Revista Brasileira de Comércio Exterior, nº 68 (jul-set), pp. 1-16. 
BOUZAS, Roberto (2002). “Mercosur: Crisis Económica o crisis de la integración?”. In: HUGUENEY FILHO, C.; CARDIM, C. H. (org.). Grupo de Reflexão Prospectiva sobre o Mercosul. Brasília: FUNAG/IPRI/SGIE/BID, pp.47-61.

CAMPOS MELLO, Flavia (2000). Regionalismo e Inserção Internacional: Continuidade e Transformação da Política Externa Brasileira. Tese de doutoramento apresentada ao Departamento de Ciência Política da Universidade de São Paulo.

CARR, Edward H. (2001). Vinte Anos de Crise: 1919-1939. Uma Introdução ao Estudo das Relações Internacionais. São Paulo: Imprensa Oficial / Editora UnB / IPRI.

CASTRO, Marcus F. (2005). Política e Relações Internacionais. Brasília: Editora Universidade de Brasília.

CAUBET, Christian G. (1991). As Grandes Manobras de Itaipu: energia, diplomacia e direito na Bacia do Prata. São Paulo: Acadêmica.

CEPAL (1994). O Regionalismo Aberto na América Latina e no Caribe: A Integração Econômica a Serviço da Transformação Produtiva com Equidade. In: BIELSCHOWSKY, Ricardo (org.). Cinqüenta Anos de Pensamento na CEPAL. Conselho Federal de Economia / Record. Rio de Janeiro.

CERVO, Amado L.; BUENO, Clodoaldo (1992). História da Política Exteriror do Brasil. São Paulo: Ática.

CERVO, Amado L. (2001). Relações Internacionais da América Latina: Velhos e Novos Paradigmas. Brasília: IBRI, 2001.

ESCUDÉ, Carlos (1997). “Política Exterior Argentina: as exigências da coerência”. In: Revista Brasileira de Comércio Exterior, no 53 (out-dez). 
FAWCETT, Louise; HURRELL, Andrew (1995). Regionalism in World Politics. Regional Organization and International Order. New York: Oxford University Press.

FLORÊNCIO, Sérgio A. Lima; ARAÚJO, Ernesto H. Fraga (1998). Mercosul Hoje. São Paulo: Alfa-Ômega.

FONSECA JR., Gelson (1998). A Legitimidade e Outras Questões Internacionais. Poder e Ética entre as Nações. São Paulo: Paz e Terra.

FREDERICO, Fábio R. (2001). A Área de Livre Comércio das Américas e as Políticas Externas de Argengina e Brasil (1994-2001): Uma Análise Comparativa. Dissertação de mestrado apresentada ao Programa de Pós-Graduação em Integração da América Latina (PROLAM) da Universidade de São Paulo.

GRIECO, Joseph (1993). "Understanding the Problem of International Cooperation: The Limits of Neoliberal Institucionalism and the Future of Realist Theory" in: BALDWIN, David (ed.) Neorealism and Neoliberalism: The Contemporary Debate. New York: Columbia University Press, pp. 301-388.

GRIECO, Joseph (1997). "Systemic Sources of Variation in Regional Institucionalization in Western Europe, East Asia, and the Americas" in: MANSFELD, Edward D; MILNER, Hellen (eds.). The Political Economy of Regionalism. New York: Columbia University Press.

HAAS, Ernst (1958). The Uniting of Europe: Political, Social and Economic Forces. Londres: Stevens.

HAAS, Ernst (1961). "International Integration: the Europeam and the Universal Process" in: International Organization, vol. 15, nº 3 (summer), pp. 366-392.

HOBBES, Thomas (1999). Leviatã ou Matéria, Forma e Poder de um Estado Eclesiástico e Civil. Coleção Os Pensadores. São Paulo: Nova Cultural. 
HURRELL, Andrew (1995). “O Ressurgimento do Regionalismo na Política Mundial” in: Contexto Internacional, vol. 17, nº 1 (jan-jun), pp. 23-59.

JAGUARIBE, Helio. “Argentina e Brasil diante de suas alternativas históricas”. In: Política Externa, vol. 9, no 3 (dez-jan), pp. 25-41.

KEOHANE, Robert O. (1988). Después de la Hegemonia. Buenos Aires: Grupo Editor Latinonoamericano.

KEOHANE, Robert O. (1993). Instituiciones Internacionales y Poder Estatal. Ensayos sobre Teoría de las Relaciones Internacionales. Buenos Aires: Grupo Editor Latinonoamericano.

KEOHANE, Robert O.; NYE, Joseph S. (1988). Poder e Interdependencia. La Politica Mundial em Trancisión. . Buenos Aires: Grupo Editor Latinonoamericano.

KRASNER, Stephen D. (1982). "Regimes and the Limits of Realism: Regimes as Autonomous Variables” in: International Organization, vol. 36, nº 2, pp. 497-510.

LAFER, Celso (2001). A Identidade Internacional do Brasil e a Política Externa Brasileira. São Paulo: Perspectiva.

LAMPREIA, Luiz Felipe (1999). Diplomacia Brasileira: palavras, contextos e razões. Rio de Janeiro: Lacerda Ed.

LAVAGNA, Roberto (1999). "Zona de Livre Comércio ou área de decisão brasileira? Fim da integração ou a insuportável leveza das propostas?’. In: Revista Brasileira de Comércio Exterior, $\mathrm{n}^{\mathrm{o}} 61$ (out/dez), pp. 1-8. 
LIMA, Maria Regina S.; HIRST, Mônica (1994). "O Brasil e os Estados Unidos: dilemas e desafios de uma relação complexa”. In: FONSECA JR., Gélson; CASTRO, Sérgio H. N. (coord.) Temas de Política Externa Brasileira II. São Paulo: Paz e Terra.

LIMA, Maria Regina S. (2005). “Aspiração Internacional e Política Externa”. In: Revista Brasileira de Comércio Exterior, no 82 (jan-mar), pp. 4-19.

LULA DA SILVA (2002). Entrevista: Luiz Inácio Lula da Silva, José Serra e a futura política externa brasileira. In: Política Externa, vol. 11, no 2 (set-nov), pp. 5-11.

MEARSHEIMER, John J. (1994). “The False Promise of International Institutions”. In: International Security, vol. 19, $\mathrm{n}^{\mathrm{o}} 3$ (witer), pp. 5-49.

MEARSHEIMER, John J. (2001). The Tragedy of Great Power Politics. New York/London: W. W. Norton \& Company.

MELLO, Leonel I. A. (1996). Argentina e Brasil: a balança de poder no Cone Sul. São Paulo: Annablume.

MITRANY, David (1948). "The Funcional Approach to World Organization" in: International Affairs, vol. 24, $\mathrm{n}^{\mathrm{o}} 3$ (jul), pp. 350-363.

MORGENTHAU, Hans (2003). A Política Entre as Nações. São Paulo: Imprensa Oficial/ Editora UnB / IPRI.

OLIVEIRA, Amâncio J.; SENNES, Ricardo U (2001). “Teoria Sincrônica da Integração Regional: Matrizes Teóricas e Percepção das Elites do Mercosul”. In: Contexto Internacional, vol. $23, n^{\circ} 1$ (jan/jun), pp. 77-110. 
ONUKI, Janina (2002). As Mudanças da Politica Externa Argentina no Governo Menem (1989-1999). Tese de doutoramento apresentada ao Departamento de Ciência Política da Universidade de São Paulo.

PEÑA, Felix (2000). “Sobre o Futuro do Mercosul”. In: Política Externa, vol. 8, nº 3 (dez/fev) pp. 3-14.

PINHEIRO, Letícia (2000). “Traídos pelo Desejo: Um Ensaio sobre a Teoria e a Prática da Política Externa Brasileira Contemporânea” in: Contexto Internacional, vol. 22, nº 2 (jul/dez), pp. $305-335$.

RAPOPORT, Mario; MADRID, Eduardo (1998). “Os países do Cone-Sul e as grandes potências”. In: CERVO, Amado L.; RAPOPORT, Mario (orgs.). História do Cone Sul.Rio de Janeiro: Revam; Brasília: Editora Universidade de Brasília.

SCHMITTER, Philippe C. (1970). “A Revised Theory of Regional Integration” in: International Organization, vol. 24, $\mathrm{n}^{\circ} 4$ (autumn), pp. 836-868.

SECRETARIA DO MERCOSUL (2004). Primer Informe Semstral de la Secretaría del Mercosur. Un Foco para el Proceso de Integración Regional. Montevidéo (julho 2004).

VEIGA, Pedro da Motta (2004). “A estratégia brasileira e suas implicações potenciais”. In: Revista Brasileira de Comércio Exterior, no 78 (jan-mar), pp.13-16.

VIGEVANI, Tullo; MARIANO, Marcelo P., MENDES, Ricardo G. (2002). "Instituições e Conflitos Comerciais no Mercosul" in: São Paulo em Pespectiva, vol. 16, nº 1 (jan-mar), pp. 44-53.

VIZENTINI, Paulo F. (1998). A Política Externa do Regime Militar Brasileiro:

Multilateralização, desenvolvimento e a construção de uma potência. Porto Alegre: Editora da Universidade/UFRGS. 
VILLA, Rafael A. D. (2005). “A Política Externa do Governo Lula: Continuidades e Rupturas". In: São Paulo: Revista ADUSP, no 34 (maio), pp. 12-19.

WALTZ, Kenneth N. (2002). Teoria das Relações Internacionais. Lisboa: Gradiva. 